\title{
RELAÇÕES SOLO, SUBSTRATO GEOLÓGICO E SUPERFÍCIES GEOMÓRFICAS NA MICROBÄCIA DO RIBEIRÃO MARINS (PIRACICABA, SP)
}

\section{EDSON ROBERTO TERAMOTO \\ Engenheiro Agrônomo}

Orientador Dr. IGO FERNANDO LEPSCH

Dissertação apresentada à Escola Superior de Agricultura "Luiz de Queiroz", da Universidade de São Paulo, para obtenção do título de Mestre em Agronomia; Área de Concentração: Solos e Nutrição de Plantas.

$P \mathbb{R A C I C A B A}$

Estado de São Paulo - Brasill

Março - 1995 
CATALOQATCO HA PUELICARAO

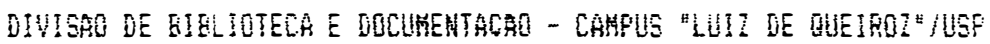

Teramutu. Edeun nütertu

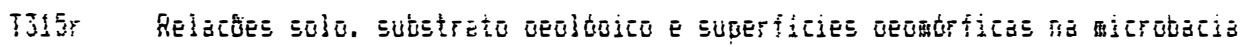

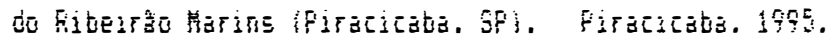

Fĩu. ilus.

DiEE. (HAEEtrE) - ESALE

Eitujuorafia.

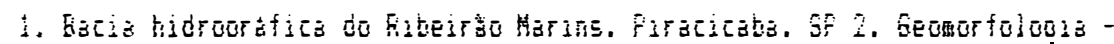

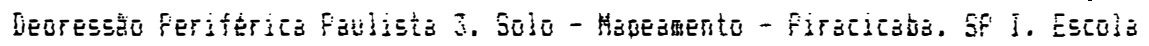
Sugerier de Aoricultura Luiz de Guejroz. Firacicata

000631.47 


\section{RELAÇÕES SOLO, SUBSTRATO GEOLÓGICO E SUPERFÍCIES GEOMÓRFICAS NA MICROBACIA DO RIBEIRÃO MARINS (PIRACICABA, SP)}

Aprovada em 02 de Junho de 1995.

Comissão Julgadora:

Prof. Dr. Carlos Roberto Espíndola FEAGRI/UNICAMP

Prof. Dr. Pablo Vidal-Torrado ESALQ/USP

Prof. Dr. Igo Fernando Lepsch ESALQ/USP

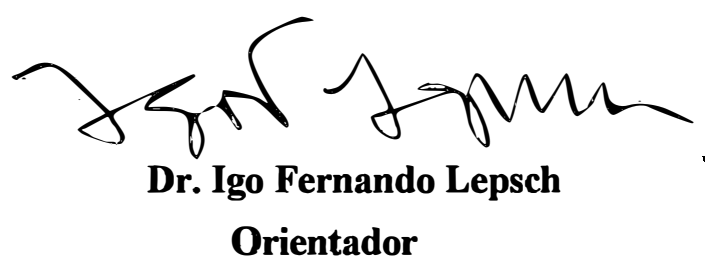


A minha FAMÍLIA

OFEREÇO ...

Aos meus PAIS ... DEDICO. 


\section{AGRADECIMENTOS}

- À Escola Superior de Agricultura "Luiz de Queiroz" e ao Departamento de Ciência do Solo pela oportunidade.

- Ao CNPq e à FAPESP pelo auxílio financeiro.

- Ao Dr. Igo Fernando Lepsch pela amizade e orientação.

- Ao amigo Miguel Cooper, pela elaboração do Summary.

- Ao Quirijn de Jong Van Lier e ao Prof. Gerd Sparovek pela elaboração do índice de homogeneidade, que foi de extrema utilidade.

- Aos amigos Guido e Raul, pela preparação do material para a apresentação.

- Aos Professores Dr. Gerd Sparovek e Dr. Pablo Vidal Torrado, pela grande amizade, pelas oportunidades e pelo apoio durante todos esses anos.

- À todos que de alguma forma contribuiram para a realização deste trabalho. 


\section{SUMÁRIO}

LISTA DE FIGURAS

PÁGINA

LISTA DE TABELAS vii

RESUMO ix

SUMMARY .. $\mathrm{x}$

1. INTRODUÇÃO. xii

2. REVISÃO BIBLIOGRÁFICA 3

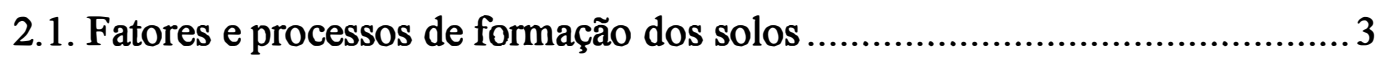

2.1.1. O material de origem como fator de formação do solo ................. 5

2.1.2. O relevo como fator de formação do solo .................................... 9

2.2. Relação entre pedologia e geomorfologia................................................ 12

2.3. Relações solo-paisagem na Depressão Periférica Paulista........................... 15

2.4. Importância de estudos sobre relações solo-paisagem.................................. 17

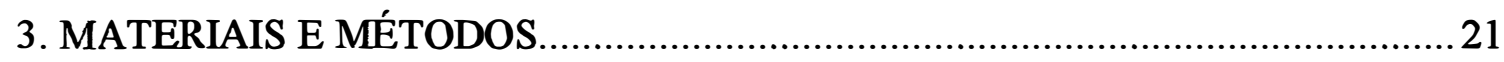

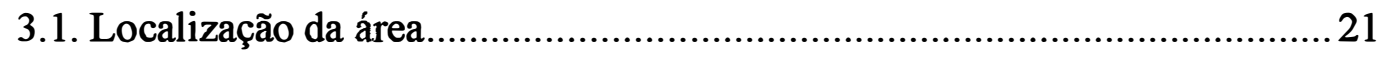

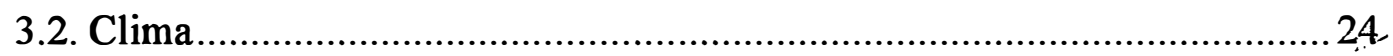

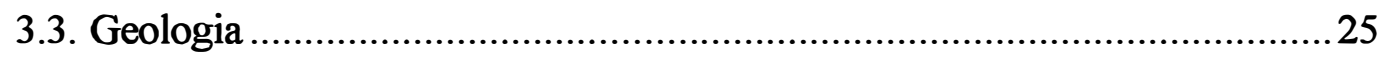

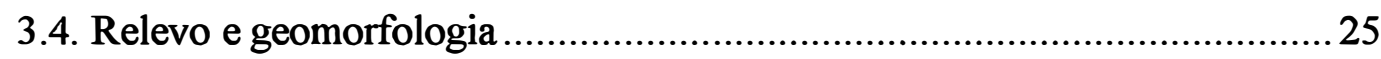

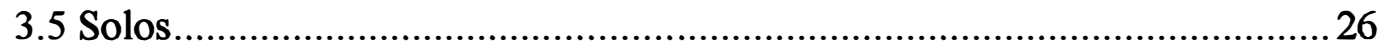

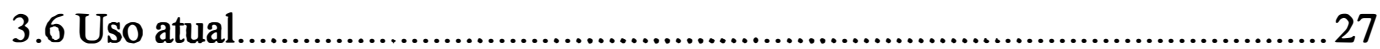

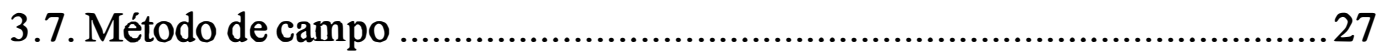

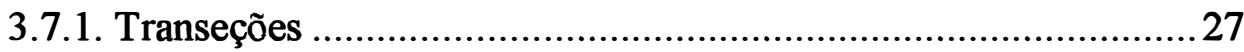

3.7.2. Mapeamento das superfícies geomórficas .................................. 28

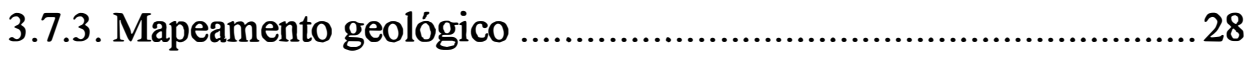

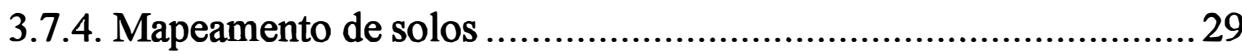

3.7.4.1. Amostragem de solos ................................................. 29

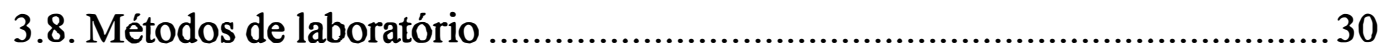

3.8.1. Análises quimicas............................................................ 30

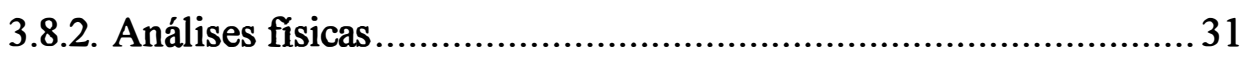

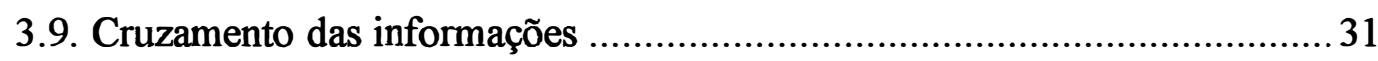

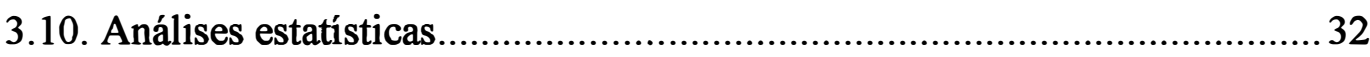

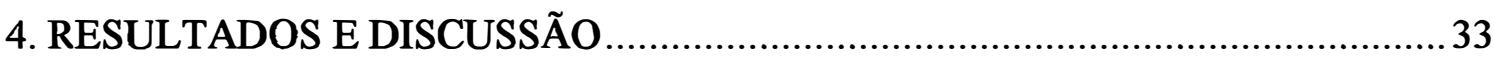

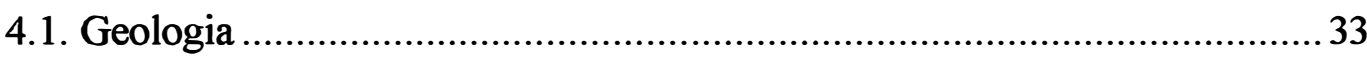




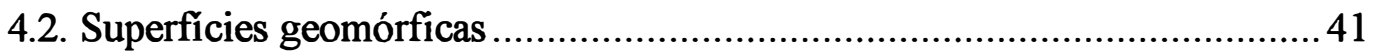

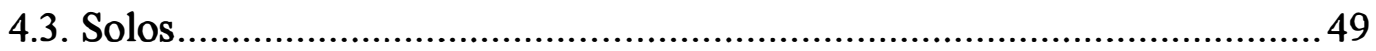

4.3.1. Legenda do Mapa de Solos...................................................... 51

4.3.2. Latossolo Vermelho-Amarelo..................................................... 52

4.3.3. Podzólico Vermelho-Amarelo ................................................. 53

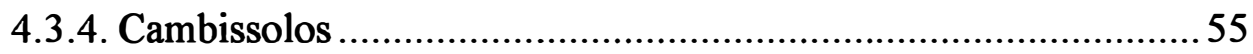

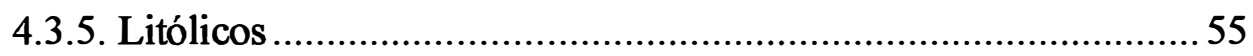

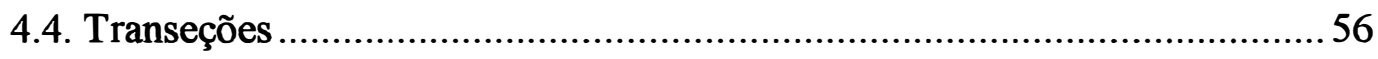

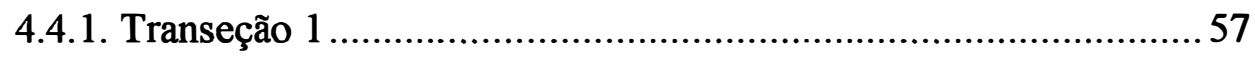

4.4.1.1. Atributos químicos..................................................... 59

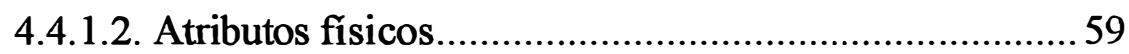

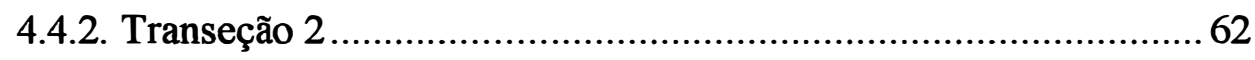

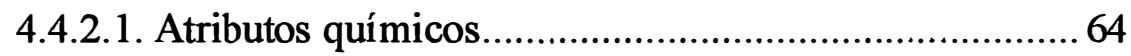

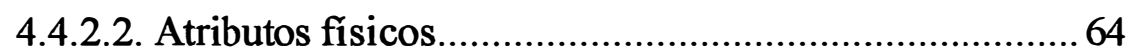

4.5. Relações solo - substrato geológico - superficies geomórficas .....................65

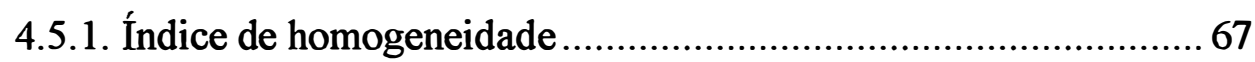

4.5.2. Relações substrato geológico-superfícies geomórficas ................. 68

4.5.3. Relações solos-substratos geológicos ………............................. 70

4.5.4. Relações solos-superfícies geomórficas .................................... 71

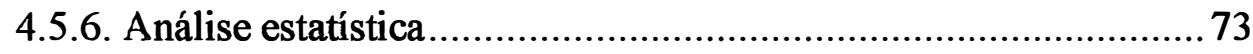

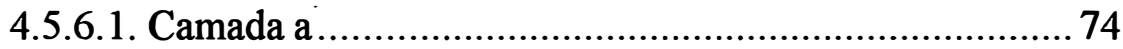

4.5.6.2. Camada b............................................................. 75

4.5.6.3. Comentários gerais sobre as camadas a e b .................. 79

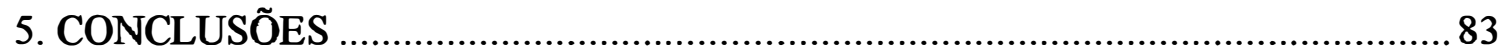

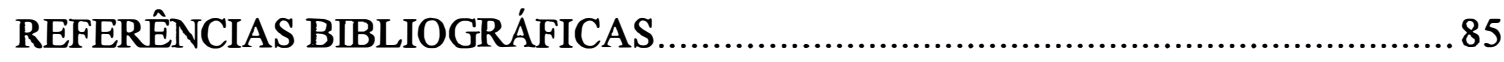




\section{LISTA DE FIGURAS}

Figura 1. Localização da área de estudo no Estado de São Paulo.

PÁGINA

Figura 2: Mapa planialtimétrico da área de estudo, sua localização em relação a microbacia do ribeirão Marins, mostrando a posição das transeções 1 e 2 , e dos cortes $A B$, CD e EF.

Figura 3: Balanço hídrico segundo Thornwaite da região de Piracicaba.

Figura 4: Esquema da metodologia para cruzamento das informações dos mapas temáticos. Cada ponto ou "pixel" possui coordenadas $\mathrm{x}$, y que são as mesmas em cada um dos mapas.

Figura 5: Coluna estratigráfica da área de estudo. 33

Figura 6: Mapa geológico da área de estudo. 34

Figura 7: Perfil topográfico mostrando a falha geológica normal localizada na vertente da transeção 2 evidenciando o abatimento da camada de arenito posicionando-a na cota $540 \mathrm{~m}$ de altitude.

Figura 8: Distribuição estatística de 5 frações de areia referentes à cobertura neo-cenozóica, formação Pirambóia e formação Corumbataí.

Figura 9: distribuição do teor de argila e da relação areia muito fina/fina $(\mathrm{AMF} / \mathrm{F})$, na tradagem profunda realizada no topo da área.

Figura 10: Bloco diagrama representando o relevo do local estudado e das áreas vizinhas. as transeções 1 e 2 também estão representadas.

Figura 11: Mapa de superfícies geomórficas. 43

Figura 12: Cortes esquemáticos mostrando as diferentes superfícies geomórficas, onde $\mathrm{AB}$ e $\mathrm{CD}$ estão indicados no mapa da figura 2 . Os solos que ocorrem nestes cortes estão representados por suas respectivas legendas e estão indicadas na figura 14 . 
Figura 13: Corte esquemático EF mostrando duas vertentes cujos topos estão em cotas iguais porém com superficies geomórficas diferentes. Os solos que ocorrem neste corte estão representados por suas respectivas legendas e estão indicadas na figura 14

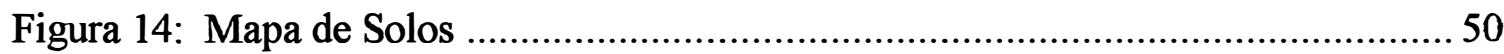

Figura 15: Perfil topográfico da transeção 1 .......................................................... 57

Figura 16: Gráficos de alguns atributos químicos e físicos da transeção 1 , em duas camadas.

Figura 17: Esquema ilustrando a disposição hipotética da estratigrafia abaixo da transeção 1. De acordo com este esquema, a partir da metade desta transeção, o material abaixo da cobertura cenozóica passa a ser relativo à formação Corumbataí. Isso explicaria o aumento do teor de cálcio, argila, de silte e da relação AMF/F (Figura 18) e da distribuição das frações areia (Figura 8).

Figura 18: Perfil topográfico da transeção 2.

Figura 19: Gráficos de alguns atributos químicos e físicos da transeção 2, em duas camadas.

Figura 20: Esquema apresentando os diferentes mapas temáticos. A partir destes mapas é possível, à primeira vista, tecer algumas relações entre os solos, a litologia e as superficies geomórficas. 


\section{LISTA DE TABELAS}

Tabela 1: Área de ocorrência das formações geológicas e depósitos superficiais e respectiva porcentagem em relação a área total.

PÁGINA

Tabela 2: Área das superficies geomórficas e sua porcentagem em relação à área total.

Tabela 3: Área de ocorrência das unidades de mapeamento e respectiva porcentagem em relação à área total.

Tabela 4: Porcentagem de ocorrência e indices de homogeneidade litológico dos substratos geológicos de acordo com as respectivas superfícies geomórficas (porcentagem em relação à área da superfícies).

Tabela 5: Porcentagem de ocorrência e índice de homogeneidade pedológico dos solos de acordo com os respectivos substratos geológicos (porcentagem em relação à área do substrato geológico).

Tabela 6: Porcentagem de ocorrência e indice de homogeneidade pedológico dos solos de acordo com as respectivas superficies geomórficas (porcentagem em relação à área da superfícies).

Tabela 7: Distribuição das amostras nas superficies geomórficas por camada amostrada.

Tabela 8: Médias de alguns atributos químicos e físicos da camada a em cada superfície geomórfica. Letras iguais indicam que as médias não diferem ao nível de $5 \%$ pelo teste Tukey.

Tabela 9: Coeficientes de variação (\%) de alguns atributos químicos e físicos da camada a em cada superficie geomórfica.

Tabela 10: Médias de alguns atributos químicos e físicos da camada $b$ em cada superfície geomórfica. Letras iguais indicam que as médias não diferem ao nível de $5 \%$ pelo teste Tukey.

Tabela 11: Coeficientes de Variação de alguns atributos químicos e físicos da camada $b$ em cada superfície geomórfica.

Tabela 12: Análise qualitativa das tendências de alguns atributos químicos e físicos das camadas a e b. As superfícies estão dispostas em uma ordem correspondentes aos valores dos respectivos atributo. 


\section{RELAÇÕES SOLO, SUBSTRATO GEOLÓGICO E SUPERFÍCIES GEOMÓRFICAS NA MICROBACIA DO RIBEIRÃO MARINS (PIRACICABA, SP)}

\section{RESUMO}

Realizou-se um estudo das relações entre os solos, a geologia e as superfícies geomórficas de uma área situada na Depressão Periférica Paulista, na microbacia do ribeirão Marins em Piracicaba, SP. A área é um segmento representativo desta microbacia em termos de solos e fisiografia, e pode ser considerada também como representativa de boa parte do município de Piracicaba quanto a esses aspectos.

Para este estudo efetuou-se um mapeamento da geologia, das superfícies geomórficas e um mapa detalhado de solos, utilizando-se como base cartográfica mapa planialtimétrico nas escala 1:10.000 e fotografias aéreas na escala aproximada de 1:25.000 como apoio. Foram realizadas duas transeções, uma no topo da área, com $1000 \mathrm{~m}$ de extensão, e outra vertente abaixo, até o ribeirão Marins, com $2500 \mathrm{~m}$ de extensão, com o objetivo de verificar a variação lateral dos solos. Nessas transeções foram feitas coletas de solo a cada $50 \mathrm{~m}$ onde foram amostradas duas profundidades $0-20 \mathrm{~cm}$ e $60-80 \mathrm{~cm}$ tidas como representativas do horizonte A e B, este último quando existente, respectivamente. As relações entre os solos, geologia e superfícies geomórficas foram feitas geograficamente, através do cruzamento dos mapas temáticos de modo que os resultados foram expressos em termos de área dessas relações. Essas relações foram analisadas comparando-se a homogeneidade pedológica ou litológica para cada relação estudada. Para isso foi proposto um "índice de homogeneidade", que se mostrou bastante eficiente. Este índice foi obtido pela média ponderada da ocorrência, na superfície geomórfica considerada, de determinados fatores sendo que os pesos são os próprios valores de ocorrência destes. Foram feitos testes de comparação de médias, através de análise de variância de atributos físicos e químicos dos solos em cada superfície.

A estratigrafia está representada por uma cobertura cenozóica de textura média, arenitos da formação Pirambóia do grupo São Bento, siltitos e folhelhos da formação Corumbataí do gnupo Passa Dois e sedimentos coluviais e aluviais. Foi verificada 
uma falha geológica numa vertente, o que fez com que os arenitos se situassem em cotas inferiores. Foram identificadas 5 superfícies geomórficas. A superficie I é a mais antiga seguida respectivamente da II, III, IV e V, sendo que esta última superfície foi dividida em sua porção erosional e deposicional. Com o levantamento de solo foram estabelecidas 10 unidades de mapeamento e quatro classes de solos: Latossolo Vermelho-Amarelo, Podzólico Vermelho-Amarelo, Litólicos e Cambissolos

A relação que existe entre solos e superficies geomórficas é representada pela tendência de que quanto mais velha e estável é a superfície mais homogênea ela é em relação aos solos que nela ocorrem. Os atributos dos solos apresentam menor variabilidade nas superfícies I e II, mais antigas e estáveis, e maior nas superfícies IV e V, mais jovens e menos estáveis. A análise estatística mostrou que existem dois grupos de superfícies geomórficas cada um com características de geologia, solos e relevo distintos. Essa separação coincide com a mudança de material de origem de arenito para siltito. Um é formado pelas superfícies geomórficas I, II e III e outro formado pelas superfícies IV, V e Vd. Isso mostra que existem dois sistemas geomorfológicos na mesma encosta, cada um com uma dinâmica própria dentro da paisagem. Dentro de cada superfície geomórfica os solos apresentaram variações, sendo que a variabilidade morfológica dos solos foi atribuida principalmente ao fator relevo e microrelevo e a variabilidade dos atributos físicos e químicos foi influenciada principalmente pelo material de origem.

O Latossolo Vermelho-Amarelo textura média está relacionado à cobertura neocenozóica e à superfície I, onde o relevo é plano. Os Podzólicos VermelhoAmarelos abruptos de textura predominantemente arenosa/média relacionam-se ao arenito da formação Pirambóia, às superfícies II e III em relevo suave ondulado. Os Litólicos argilosos estão associados aos siltitos e sílex da formação Corumbataí, às superfícies IV e $\mathrm{V}$ em relevo ondulado e escarpado. Os Cambissolos de textura variada relacionam-se aos alúvios-colúvios presentes na superficie $\mathrm{V}$ deposicional em relevo plano a suave ondulado, no fundo dos vales e nas margens do ribeirão. Estas relações, estabelecidas na área de estudo, se repetem na paisagem de outros locais da microbacia com características de solo, relevo e litologia semelhantes a da área estuda. Isso mostra que as relações estabelecidas na área estudada podem ser extrapoladas para outras, contribuindo dessa forma para futuros levantamentos de solos que possam vir a ser realiazados nessa microbacia 


\section{SOIL, GEOLOGICAL SUBSTRACT AND GEOMORPHIC SURFACE RELANTIONSHIPS IN THE MARINS RIVER BASIN (PIRACICABA, SP, BRAZIL)}

Author: EDSON ROBERTO TERAMOTO

Adviser: Dr. IGO FERNANDO LEPSCH

\section{SUMMARY}

The relationship between soils, geology and geomorphic surfaces were studied in the Marins basin in Piracicaba, S.P. This area is locate in the Paulista Peripheric Depression. The study area is a representative segment of this basin in terms of soils and fisiography, and in these aspects it can be considered to be representative of a large part of the Piracicaba region

Soils, geology and geomorphic surfaces were mapped for this study. Two mansects were studied to verify the lateral variation of the soils. The geology is represented by Neo-Cenozoic surficial deposits of loamy sand texture, sandstone belonging to the Piramboia formation of the São Bento group, siltstones and shales belonging to the Corumbatai formation of the Passa Dois group and colluvial and alluvial sediments. Five geomorphic surfaces were identified. The relations between soils, geology and geomorphic surfaces were done geographically, by crossing the different maps in a way that the results were expressed in terms of area. These relations were analized comparing the pedological or lithological uniformity for each relation studied. For this purpose an "uniformity index" was proposed which showed to be efficient. Mean comparison tests were done using variance analysis of soil physical and chemical attributes in each surface.

Ten soil units were identified. Well developed and weathered soils were found in the higher positions of the landscape. In the intermediate positions, soils with a high textural gradient and with an argillic horizon were found and in the lower positions poorly developed soils were identified. Due to a geological fault on one of the transects, the sandstone was found in a lower position of the landscape.

The relation that exists between the soils and the geomorphic surfaces is represented by the tendency that the older and more stable the surface is, more homogeous it is in relation to the soils formed on it. The soils attributs present less 
variability on the surface I and II, older and more stable, and higher on the surfaces IV and $\mathrm{V}$, younger and less stable. These analysis also showed that a division exists between the geomorphic surfaces, suggesting that two different groups of surfaces exist on the same transect. One is formed by the geomorphic surfaces I, II and III and the other is formed by the surfaces IV, V and Vd. The first group has different geological, soil and relief characteristics when compared with the second group, and each have a unique dynamics in the landscape. In each geomorfic surface the soils presented variations, this soil morphological variabilits was attributed principally to the relief and microrelief factor and and the variation of the phisical and chemical attributes was influencied principally by the parent material.

The Oxisol is related to the neocenozoic cover and surface $\mathrm{I}$, were the relief is flat. The Ultisol with predominance of a sand loam texture are related to the Pirambóia formation sandstone and to surface II and III in a gentle sloping relief. The Litholic soils with a clayey texture are associated with the Corumbatai formation siltstone and silex and to the IV and V surfaces in a ondulating and scarped relief. The Inceptsols of varied textures are related to alluvium and colluvium deposits present on the depositional surface $\mathrm{V}$ in a flat and gentlesloping relief, at the botton of the valleys and margins of the stream.

This relation, established in this area of study, are repeated in the landscape in other location of the basin with soil, relief and lithological characteristics similar to the ones of the studied area. this shows that the relations established in this area can be extrapolated to others, contibuting in this way to future soils surveys that could be done in this basin. 


\section{INTRODUÇÃO}

O material de origem e o relevo, entre outros, são importantes fatores de formação dos solos e exercem grande influência na gênese dos mesmos. Essa influência é verificada principalmente através da posição topográfica que os solos ocupam na paisagem, evidenciando que existe uma relação entre os solos, a forma do terreno na qual ocorrem e a geologia local. Na realidade, ao se estudar as relações entre os objetos da natureza, verifica-se que essas relações são dinâmicas e que esses objetos não podem ser estudados de forma isolada.

O relevo, expresso pela forma do terreno, é condicionado pelas características do material rochoso, ou seja, pela geologia. $\mathrm{O}$ material de origem tem sua posição na paisagem determinada pela estratigrafia e pelo relevo, uma vez que os agentes que esculpem o relevo também expõe o material geológico. As características morfológicas, físicas e químicas dos solos dependem, entre outros fatores, do relevo e do material de origem. Dessa forma torna-se incoerente estudar a gênese e distribuição dos solos de uma região sem também estudar os fatores que influenciam a sua dinâmica na paisagem.

Os estudos das relações entre os solos, o substrato rochoso e as superfícies geomórficas permitem a interpretação e a solução de problemas simples até os mais complexos. Mas a grande utilidade está nas atividades de mapeamento de solos, pois com o conhecimento prévio das relações que existem entre os solos, o relevo e a geologia, é possível estabelecer padrões de ocorrência e dessa forma prever os solos que podem existir em um determinado relevo em determinada região. Isto também possibilita a redução de custos, uma vez que a ida constante ao campo é evitada, o número de amostras a serem coletadas diminui, assim como tempo de execução do trabalho.

Em estudos. de relações solo-paisagem o trabalho de campo é uma etapa fundamental, pois é na natureza que o pedólogo deve buscar o entendimento dessas 
relações, através da interação de informações sobre a geologia, hidrologia, estratigrafia e da pedologia. Dessa forma um trabalho de campo bem realizado pode ser muito valioso pois tem o potencial de gerar mais informações que muitas análises de laboratório.

Com a finalidade de se efetuar estudos para a compreenção das relações entre solos, substratos geológicos e superfícies geomórficas, escolheu-se um local de trabalho situado na microbacia do ribeirão Marins, município de Piracicaba, com cerca de 450 ha como subsídio para futuros levantamentos de solos que poderão ser realizados nesta microbacia e arredores. Esta área constitui um segmento representativo em termos de solos e físiografia da microbacia e de boa parte do município de Picacicaba. 


\section{REVISÃO BIBLIOGRÁFICA}

\subsection{Fatores e processos de formação dos solos}

Em 1898 Dokuchaev (citado por BUOL, 1980) tentou expressar a formação do solo através de uma equação onde a pedogênese seria função de alguns fatores formadores do solo:

$$
S=f(c l, o, m)^{t}
$$

Segundo essa equação pioneira, o desenvolvimento dos solos (S) seria função do clima (cl), organismos atuantes (o) e do material de origem (m) agindo durante determinado tempo $(\mathrm{t})$.

Estudos posteriores realizados a partir deste conceito mostraram que o relevo tem grande influência sobre a formação dos solos. Então JENNY (1941) introduziu o fator relevo na equação acima.

$$
\mathrm{S}=\mathrm{f}(\mathrm{cl}, \mathrm{o}, \mathrm{m}, \mathrm{r}, \mathrm{t}, \ldots)
$$

Nesta equação, o tempo é considerado como o período desde o estágio inicial da formação do solo e as reticências indicam que outros fatores não específicos, e de natureza variada, em situações particulares, podem influenciar e participar da formação dos solos.

Desde Dokuchaev até hoje muitos fatores foram identificados como tendo alguma importância na formação do solo mas apenas alguns foram selecionados para 
servir de base para investigações pedológicas. Assim JENNY (1941) considerou em sua equação 5 fatores de formação como sendo mais importantes: clima, organismos, relevo, material de origem e tempo. BIRKELAND (1984) também definiu estes mesmos, concordando que outros fatores podem ter importância local, mas estes cinco fatores influenciariam a maioria dos solos. Por outro lado, BUOL et al. (1980), em uma definição generalizada, consideram como fatores de formação do solo, agentes, forças, condições, ou combinação destes que influenciaram, influenciam ou podem vir a influenciar o material de origem com o potencial de muda-lo.

Os fatores que constituem a equação fundamental são interdependentes entre si, podendo ser estudados sequências de solos onde apenas um dos fatores varia, enquanto os outros permanecem constantes. Dessa forma JENNY (1941) modificou a equação fundamental e estabeleceu as seguintes funções:

$$
\begin{aligned}
& \mathrm{S}=\mathrm{f}(\mathrm{cl}, \mathrm{o}, \mathrm{m}, \mathrm{r}, \mathrm{t}, \ldots) \text { climofunção } \\
& \mathrm{S}=\mathrm{f}(\mathrm{o}, \mathrm{cl}, \mathrm{m}, \mathrm{r}, \mathrm{t}, \ldots) \text { biofunção } \\
& \mathrm{S}=\mathrm{f}(\mathrm{m}, \mathrm{cl}, \mathrm{o}, \mathrm{r}, \mathrm{t}, \ldots) \text { litofunção } \\
& \mathrm{S}=\mathrm{f}(\mathrm{r}, \mathrm{cl}, \mathrm{o}, \mathrm{m}, \mathrm{t}, \ldots) \text { topofunção } \\
& \mathrm{S}=\mathrm{f}(\mathrm{t}, \mathrm{cl}, \mathrm{o}, \mathrm{m}, \mathrm{r}, \ldots) \text { cronofunção }
\end{aligned}
$$

O fator que está em primeiro lugar na equação é o que varia, enquanto os demais, teoricamente, permanecem constantes. Estas equações permitem idealizar situações onde a formação do solo é influenciada preferencialmente por um fator. Para esta situação JENNY (1980) denominou de "fatores dominantes" aqueles que variam e de "fatores subordinados" aqueles que não variam.

BUOL et al. (1980) e BIRKELAND (1984) também citam que o estudo da gênese do solo pode ser realizada através de métodos que o toma em conta como variável dependente ou como variável independente.

O conceito de processos de formação dos solos foi descrito por SIMONSON (1959) como um modelo tridimensional de ganhos, perdas, transformações e translocações no sistema solo que até então era algo baseado em um conceito bidimensional. Segundo o autor, todos os solos estão sujeitos aos mesmos processos pedogenéticos, entretanto em diferentes graus e combinações. Todos eles podem tanto promover a formação e diferenciação dos horizontes como também retardá-las. 
A partir deste modelo, o solo passou a ser definido como um sistema aberto no qual ocorrem perdas e ganhos de matéria e energia através de seus limites. Essa concepção de solo envolve uma série de conceitos básicos que inclue o fluxo de energia e de matéria através de seus limites, que podem ser reais ou arbitrários. A matéria pode ser transportada de um local para outro ou pode ter suas propriedades físicas transformadas por reações químicas. Um conceito importante é que sistemas abertos tendem a estar em equilíbrio dinâmico ou "stead state", ou seja, a taxa de matéria e energia que entra é igual a que sai, enquanto que a energia e matéria armazenada no sistema permanece constante. Quando a taxa de entrada ou saída é modificada o sistema tende a achar um novo equilíbrio e como as propriedades dos solos estão inter-relacionadas, se uma propriedade modificar outras também sofrerão mudanças (JENNY, 1941; BUOL et al.,1980; GERRARD 1981)

Assim alguns autores passaram a fazer uma distinção entre os conceitos de fatores e processos de formação dos solos.

Os processos formam os solos e os fatores definem o estado do sistema solo. Os fatores de formação são entendidos como agentes atuantes que provocam algum tipo de influência no desenvolvimento dos solos e seus atributos, enquanto os processos são os caminhos dinâmicos, reações ou mecanismos de caráter físico, químico ou biológico que produzem no solo zonas características cuja combinação é particular em cada caso, e está correlacionada com os fatores de formação. São estes processos que levam a constituição dos horizonte ou camadas particulares a cada situação ambiental (BUOL et al., 1980; BIRKELAND, 1984; VIEIRA, 1988).

Estudos onde alguns fatores são constantes e outros variam, permitem aos pedólogos uma avaliação mais efetiva do grau de influência de um fator específico no desenvolvimento e pedogênese dos atributos dos solos, uma vez que a variação observada nos solos seriam atribuídas apenas ao fator variante.

\subsubsection{O material de origem como fator de formação do solo}

O material de origem já era citado por Dokuchaev em 1883 como um importante fator de formação do solo. Tanta era sua importância que freqüentemente os solos eram designados fazendo menção à sua origem geológica, como por exemplo solos de granito ou solos glaciais (BUOL et al., 1980; BIRKELAND, 1984). 
JENNY (1941) define como material de origem o estado inicial do sistema solo no tempo zero de formação do mesmo e comenta sobre a dificuldade de se definir a última camada, horizonte $\mathrm{C}$, como sendo solo ou material de origem.

FITZPATRIK (1971) comenta que a precisão da definição de JENNY (1941) não pode ser questionada, e cita que uma das questões que causam dificuldades é a determinação dos estádios iniciais de formação dos solos. Em alguns casos onde a formação do solo se deu em curto espaço de tempo a natureza do material pode ser determinado com razoável precisão mas sempre alguma dedução é necessária.

Em estudos de litossequências, as diferenças nas propriedades dos solos seriam devido somente às diferenças no material de origem. Entretanto, é difícil que numa seqüência ou num grupo de solos, somente o material de origem influencie as suas propriedades (BUOL et al., 1980).

$\mathrm{O}$ grau de influência do material de origem sobre o solo e suas características é controlado principalmente pela intensidade dos processos de intemperismo, que é regulada basicamente pelas condições climáticas e pela natureza do material de origem, principalmente pela mineralogia. Essa relação entre material de origem e solo é descrita em ARNOLD (1983), KAMPF \& KLAMT (1978); BUOL et al. (1980), JENNY (1980) e BIRKELAND (1984).

GRAHAM \& BUOL (1990) estudando uma sequência de solos derivados de mica-gnaisse, constataram que os solos sobre material derivado do intemperismo desta rocha possuem mineralogia micácea, enquanto que em solos sobre material coluvial com alto grau de intemperismo, pobre em minerais micáceos, a mineralogia é oxidica.

A influência do material de origem também está relacionada com o grau de desenvolvimento dos solos. Segundo BUOL et al. (1980) e BIRKELAND (1984) esta influência é maior em solos jovens, ao contrário, em solos mais maduros o material de origem tem ralativamente pouca influência.

Dessa forma, a identificação do material de origem é fundamental para uma melhor avaliação do grau de influência dos diferentes fatores e processos pedogenéticos na variabilidade dos solos (ARNOLD, 1983).

Em qualquer tipo de estudo de solos, o conhecimento do material semelhante àquele que presumivelmente origina o solo em estudo é imprescindível. Mas nem sempre o material de origem apresenta-se uniforme e contínuo. Diferenças na geologia 
ou até mesmo provocados por algum evento passado podem ocorrer com certa frequência na natureza, nestes casos o material de origem não pode ser claramente identificado no campo. Em casos de desuniformidade do material, testes de descontinuidade litológica podem ser realizados (BIRKELAND, 1984).

Segundo BREWER (1976) a utilização da proporção entre minerais resistentes e não resistentes ao intemperismo pode ser um indicador de descontinuidade litológica. DEMATTÊ \& HOLLAWAYCHUC (1981) e LEPSCH (1977) utilizaram frações granulométricas entre sub-frações de areia para apontar variações no material de origem entre o horizonte A e o B. Pode-se utilizar relações entre areia muito fina/fina ou fina/grossa. NORTON \& HALL (1985) partiram do conteúdo de zircão, potássio e titânio na fração 5 a $50 \mathrm{m \mu}$ para verificar ocorrência de descontinuidade litológica. PEREZ FILHO (1980); PRADO (1986), TREMOCOLDI \& STEINHARDT (1987); VIDAL-TORRADO (1994); e COELHO et al. (1994), utilizaram parâmetros estatísticos da distribuição da granulometria das areias.

Quanto ao método de campo, a mais forte evidência para constatar descontinuidade do material de origem é a presença de linhas de pedras no perfil do solo, este fato foi destacado por RUHE (1960), embora essa evidência deva ser interpretada, em certos casos, com cautela.

Em regiões intertropicais que não sofreram efeitos das glaciações do quaternário são relativamente comuns a presença de antigas superfícies derivadas de processos de pediplanação (BIGARELLA et al., 1965) as quais podem corresponder a solos de diferentes idades. Essa linhas de pedras podem ser reflexo de mudanças climáticas que provocaram intensa morfogênese mecânica relacionada ao clima seco (BIGARELLA \& ANDRADE, 1965; PENTEADO, 1974; AZOLIN et al., 1975; , 1979; LEPSCH \& BUOL, 1986).

Não é raro encontrar na natureza perfís de solos com mudanças texturais abruptas entre horizontes, sem no entanto encontrar uma evidência de campo para explicar tal fenômeno, como a presença de linhas de pedras por exemplo. Essa mudanças texturais abruptas podem estar relacionadas a eluviação intensa das argilas ou a recobrimentos arenosos superficiais (QUEIROZ NETO, 1975; ESWARAM \& SYS, 1979; SCHWERTMANN et al., 1983;) ou podem ainda ser causadas por desuniformidade na sedimentação do próprio material de origem como foi encontrado por JIMENEZ RUEDA \& DEMATTE (1988). 
Um tipo de material de origem importante são os depósitos de materiais pré-intemperizados. As superfícies mais antigas estão geralmente sob material retrabalhado os quais tem tratados como depósitos neo-cenozóicos. Estas formações superficiais são características de regiões que não sofreram a ação de geleiras durante o quaternário e seu estudo, como o de MELO \& PONÇANO (1983) é justifícado pela considerável área que ocupam. Muitas vezes, os sedimentos das formações superficiais são confundidos com o material autóctone. Todavia, sua origem é coluvial ou aluvial, estando hoje dominantes nos interfluvios mais elevados

LEPSCH (1977) também destaca a importância da caracterização dos depósitos superficiais, uma vez que eles constituem o material de origem de uma grande parte dos solos brasileiros e ocupam expressivas áreas, principalmente no sudeste do Brasil. CRISTOFOLETTI (1983) em seu trabalho sobre as formações superficiais da região de São Pedro e Piracicaba, considera como formações superficiais o manto de materiais inconsolidados existentes logo acima das rochas sãs. Sua origem está ligada aos processos superficiais de intemperismo, de deposição e de diagênese. As questões que geralmente surgem, quanto a este assunto, são: A partir de que espessura do manto de intemperizado surge a formação superficial? Qual a espessura ou grau de diagênese que deve ser considerado para a formação superficial ou até mesmo qual seria o material de origem correlativo destas superfícies? Os depósitos superficiais são de origem deposicional ou erosional?

$\mathrm{Na}$ folha geológica de Piracicaba, a grande maioria das formações superficiais é do tipo coluvial, ficando os depositos aluviais restritos ao longo do rio Piracicaba, com manchas isoladas ao longo do rio Corumbataí. A formação Rio Claro, assenta-se em grande parte sobre a formação Pirambóia e a formação Estrada Nova . Os depósitos aluviais da formação Rio Claro aparece em areas restritas, ao longo do vale do rio Piracicaba e Corumbataí (CRISTOFOLETTI, 1983).

O material geológico tem influência fundamental na pedogênese e a sua distribuição espacial é de grande importância para a compreensão da ocorrência dos solos na paisagem. Assim sendo, estudos estratigráficos tornam-se fundamentais para se estudar a variação dos solos de uma área.

Para DANIELS \& HAMMER (1992) uma das primeiras questões a serem levantadas para estudos de campo refere-se a coluna estratigráfica na qual a área está inserida. Algumas questões são importantes para entender a variabilidade textural dos solos 
e estimar sua extensão em área, tais como: $\mathrm{O}$ material de origem faz parte de uma unidade estratigráfica uniforme ou faz parte de um material retrabalhado de ocorrência local e que raramente são mostrados em cartas geológicas? Como foi o ambiente deposicional deste material? Os autores não utilizam aqui o termo estratigrafia em seu conceito mais clássico, mas enfatizando a camada mais superficial, sua origem e propriedades, uma vez que é nessa camada que o solo se desenvolve.

GAMA FILHO (1989) comenta sobre 3 concepções estratigráficas:

a) Tradicional: Baseia-se no princípio da superposição, segundo a qual cada camada é mais jovem que a subjacente e mais velho que a sobrejacente. Relega a plano secundário a lei de correlação de facies de Walter. Uma limitação é a distorção de seus conceitos fundamentais. Estas distorções tanto conceituais como metodológica geram o conceito de "layer cake".

b) "Layer Cake": Este conceito deriva da concepção de que as formações seriam unidades tabulares geneticamente homogêneas e limitadas por superficies isócronas à semelhança de um bolo em camadas. Esta falsa idéia gerou uma série de práticas e procedimentos que são aplicadas em análise paleoambiental atuando de forma negativa na evolução da ciência estratigráfica e criou alguns sofismas conceituais:

- Camadas de bolo: falsa imagem de que as formações geológicas são unidades genéticamente uniformes e isócronas.

- Acresção tabular: falsa idéia na qual as camadas de cada formação geológica se depositariam sucessivamente em toda extensão da bacia.

c) Estratigrafia genética: $\mathrm{O}$ conceito de sistema deposicional é enfocado como um elo de ligação entre a sedimentologia e a estratigrafia pois representa ao mesmo tempo uma unidade paleofisiográfica identificável sedimentologicamente como uma associação de fácies e mapeável estratigraficamente em escala de bacia.

\subsubsection{O relevo como fator de formação do solo}

O relevo assume um importante papel na formação do solo, pois em alguns casos este é o principal agente em determinados processos pedogenéticos.

Para BUOL et al. (1980) o relevo influencia a formação do solo muitas vezes interagindo com outros fatores como o clima, material de origem e tempo. Estas 
relações tem sido muito importantes para explicar a evolução das propriedades e atributos dos solos.

Teoricamente o relevo, como fator de formação do solo, pode ser estudado isoladamente, como foi comentado anteriormente na equação de JENNY (1941). Esse tipo de estudo é realizado em topossequências e pode ser avaliado através de parâmetros topográficos (VIDAL TORRADO, 1988).

MILNE (1935) destaca-se entre os primeiros autores a estudar as relações existentes entre o relevo e os solos. Ele, a partir do estudo das variações dos solos em relação ao relevo e a drenagem na Africa do Sul, introduziu o conceito de catena na ciência do solo. Dessa forma foi possível avaliar a influência da topografia na diferenciação lateral dos solos, enfatizando que cada solo ao longo da vertente apresenta distintas relações com os solos acima e abaixo dele, por razões geomorfológicas e pedológicas. $\mathbf{O}$ autor caracterizou o termo catena como sendo uma unidade de mapeamento conveniente para descrever um grupo de solos que apesar de sofrerem modificações morfológicas e de classificação, estão ainda relacionados em sua ocorrência por condições topográficas e se repetem nas mesmas relações quando as mesmas condições são encontradas. Dessa forma as características e propriedades dos solos variam com o relevo, com a litologia e com os ciclos de erosão. Entretanto a evolução geomórfica e fisiográfica da paisagem estão ambas envolvidas no conceito de catena. $\mathrm{O}$ perfil do solo muda de ponto a ponto de acordo com as condições de drenagem e com a história passada das superfícies. Cada catena é o resultado de uma complexa interrelação entre solos e processos que ocorrem na encosta e é governada pela diferença entre as taxas de erosão e deposição que ocorrem nas diferentes partes da encosta.

MILNE (1935) considera dois tipos de catena:

a) Catena com material de origem uniforme: $A$ diferenciação dos solos é resultado apenas de diferenças nas condições de drenagem e no movimento lateral de material, tanto em superficie como em subsuperficie.

b) Catena com material de origem não uniforme: Ocorre diferenciação dos solos em função da diferença litológica além dos fatores acima citados.

A partir de 1935, os estudos sobre relações solo-relevo ganharam impulso e o conceito de catena vem sendo utilizado com frequência até os dias atuais. Este conceito foi mudando e agora confunde-se com o de topossequência. Os solos em uma 
catena diferem não apenas na morfologia mas são considerados diferentes como um resultado da erosão, transporte e deposição (HALL, 1983).

TRICART (1968) cita que o conceito de catena, que é apenas topográfico em sua origem, é válido só em relação as condições de drenagem dos solos, sendo portanto importante dar uma conotação geomórfica para este conceito.

PENTEADO (1974) concorda com a afirmação acima e sugere que o estudo da catena não deve ser apenas avaliado do ponto de vista de diferenças topográficas e lembra que não se deve esquecer das diferenças e da heterogeneidade do meio que certamente exerce grande influência no solo.

Neste contexto HALL (1983) cita que o conceito de "toposseqüência" apresenta uma conotação morfológica, refletida por alterações nas cores em função da posição ocupada pelo solo na paisagem como conseqüência de diferentes condições de drenagem, mas observa também que os solos numa topossequência não diferem apenas morfologicamente, mas apresentam também diferenças físicas, químicas e mineralógicas.

GERRARD (1981) comenta que o conceito de catena é facilmente aplicavel em áreas com uniformidade geológica, mas tem sido aplicado também com sucesso em áreas com geologia complexa.

CHAUVEL et al. (1987) comenta que toda vez que a diferenciação lateral e vertical do solo é estudada, tem sido mostrado que muitas propriedades físicas estão ordenadas no relevo, devido, entre outros fatores, ao fluxo da água. Considerando que muitos processos que governam a pedogênese e a fertilidade dependem da taxa e direção do transporte da água, o relevo assume importante papel, uma vez que o mesmo controla o fluxo de água.

Segundo GRAHAM \& BUOL (1990) a posição geomórfica que os solos ocupam na paisagem está relacionada com a natureza residual ou coluvial dos solos e tem uma forte influência nas propriedades e evolução dos mesmos. Solos em posições mais altas das encostas tem um componente residual significativo como resultado do intemperismo das rochas. Nas posições mais baixas, que são áreas deposicionais, os solos são mais profundos quando formados sobre alúvio-colúvio.

GERRARD (1990) estudou as relações solo-paisagem no sudeste da Inglaterra para testar alguns conceitos já bem estabelecidos a respeito dessas relações. $\mathbf{O}$ autor constatou que as relações existem, mas a idéia de que estas relações ocorrem ao longo de toda a extensão da encosta não é necessariamente verdade. Componentes individuais das 
encosta possuem características de solos que parecem estar relacionadas com a natureza morfológica destes componentes, ou seja, diferentes partes da encosta podem ter ação independente sobre o solo. Dessa forma a encosta como um todo não possui um sistema solo integrado a ela. Segundo o autor, isso questiona, de certa forma, a validade do emprego de alguns conceitos tradicionais, como o da catena no estudo das relações solopaisagem.

Sobre o trabalho de MILNE (1935) o mais importante talvez tenha sido o entendimento que diferentes partes de uma paisagem podem ter histórias diferentes e portanto solos diferentes.

\subsection{Relação entre pedologia e geomorfologia}

Segundo DANIELS et al. (1971) geomorfologia é a ciência que estuda a evolução da superficie terrestre ou ainda pode ser definida como um "exame sistemático das formas da paisagem e sua interpretação com a história geológica..." e pedologia "é a ciência que estuda os solos cujo limite superior é a superficie da terra...". Acrescentou ainda que geomorfólogos estão interessados em saber como a superfícíe se desenvolve, qual ou quais fatores estão envolvidos e quando estes processos começaram e terminaram. Já aos pedólogos interessam quais fatores que influenciam o desenvolvimento dos solos. Existe portanto uma relação muito grande entre estas duas ciências porque elas tratam de partes da mesma coisa.

Em geomorfologia a paisagem é vista como uma união de formas de relevo os quais são individualmente transformados durante os processos de transformação da paisagem. Como os solos são parte integrante das formas do relevo, vários estudos de processos que ocorrem na paisagem tem implicações no estudo dos processos de desenvolvimento dos solos, os quais são considerados como parte integrante da evolução da paisagem. Os conceitos e conhecimentos sobre estratigrafia e geomorfologia aplicados a problemas de solos ganharam impulso durante os últimos 20 anos e muito contribuiram para o progresso desta área (HALL, 1983).

Segundo PENTEADO (1974) a pedologia e a geomorfologia devem ser integradas uma a outra, e não devem se tornar um ramo particular constituindo cada uma uma disciplina ou ciência autônoma, pois o relevo terrestre constitui o meio no qual os solos se desenvolvem sendo portanto um dos fatores condicionadores da pedogênese. A 
geomorfologia também deve levar em conta os dados pedológicos, uma vez que a morfogênese se exerce frequentemente nos solos e não diretamente sobre a rocha. $\mathrm{O}$ processo de erosão que é o fator de esculturação da paisagem, atua diretamente sobre o solo.

McFADDEN \& KNUEPFER (1990) ilustram a importância da relação entre pedologia e geomorfologia através da idéia de que os solos se formam em qualquer lugar da paisagem, portanto a história da paisagem está intimamente ligada com a história do desenvolvimento do solo. Essa ligação que existe entre pedologia e os processos superficiais promove uma forte relação entre os estudos de gênese de solos e de evolução e estabilidade dos elementos da paisagem, uma vez que o solo é parte essencial de todo elemento da paisagem e das superficies geomórficas.

Para PENTEADO (1974) o estudo geomorfológico detalhado deve preceder a cartografia de solos, uma vez que ele fornece o estudo temporal e espacial no qual os solos evoluiram. Fornece também a descrição e localização das formações superficiais a partir das quais os solos são desenvolvidos. Essa afirmação é compartilhada por LEPSCH et al. (1977) ao afirmarem que para desenvolver princípios de relações solo paisagem é necessário mapear os solos e as superficies geomórficas separadamente para então estudar-se as relações.

Não se pode deduzir os solos a partir de sua posição na paisagem ou deduzir a história geomorfológica pelas propriedades dos solos apenas. Entretanto, uma vez estabelecida uma relação solo-geomorfologia é possivel realizar uma série de deduções sobre os solos ou a geomorfologia a partir do conhecimento de um ou do outro. $\mathrm{O}$ solo forma um corpo tridimensional na paisagem, vários estudos de gênese de solos e sua distribuição requer um entendimento da gênese da paisagem na qual eles ocorrem (HALL, 1983).

No contexto das interrelações entre a Pedologia e a Geomorfologia, o conceito de catena foi um importante passo para o entendimento das variações dos solos na paisagem. MILNE (1935) usou o termo catena como sendo uma unidade de mapeamento para descrever a repetição regular de solos na paisagem.

A pedologia, assim como a geomorfologia, são em primeira instância ciência históricas. Nesse contexto PENTEADO, (1974) ressalta que a influência dos paleoclimas no relevo atual é notável devido as importantes modificações climáticas que 
ocorreram no passado, principalmente durante o quaternário, cuja característica é a intensa instabilidade climática .

Para compreender as relações entre as características dos solos e a paisagem é necessário entender a história da paisagem na qual os solos se desenvolveram, ou seja, como a paisagem se formou, que eventos ocorreram no passado e qual a estratigrafia local.

Nesse contexto muitos autores se detiveram ao estudo da evolução das vertentes, e consequentemente à evolução da paisagem.

Segundo BIGARELLA (1965) o mecanismo da evolução das vertentes consiste essencialmente em uma sutil interação entre profundas mudanças climáticas e variações dos níveis de base locais. Durante o pleistoceno, nas áreas geográficas que mais interessam ao território brasileiro, dois diferentes conjuntos de mudanças e processos, operando alternadamente, submeteram a paisagem a degradação lateral em clima semiárido (épocas glaciais) ou a dissecação em clima úmido (épocas interglaciais). A ação erosiva seria muito efetiva no período de transição de um tipo de um clima para outro. As épocas semi-áridas foram responsáveis pela elaboração de superfícies aplainadas, pediplanos e pedimentos, enquanto que as épocas úmidas promoveram dissecação. Das primeiras restam na paisagem apenas remanescentes, formando ombreiras de inclinação pequena a média. Das épocas úmidas encontram-se formas de vertentes mais íngrimes.

Segundo YOUNG (1972) os modelos de evolução de vertentes de Davis, Penck e King sugerem que a paisagem resultou de processos erosivos atuais. No modelo proposto por Hack a vertente evolui em equilibrio dinâmico mantendo sua forma ao longo do tempo. (BIGARELLA, 1965 e DANIELS \& HAMMER,1992).

Um conceito muito importante nos estudos que envolvem geomorfologia, e relações solo-geomorfologia é o de superfície geomórfica. Definida por RUHE (1969) como sendo "uma porção da superficie terrestre perfeitamente definida no tempo e no espaço".

DANIELS et al. (1971) acrescenta que as superficies possuem limites geográficos definidos e são formadas por um ou mais agentes num determinado período de tempo. $\mathbf{O}$ autor também definiu os princípios básicos para identificação destas superfícies: a) uma superfície é mais jovem que qualquer superfície que a corta; b) uma superfície é mais velha ou contemporânea aos depósitos em posição inferior; c) é mais jovem que as superfícies situadas em posição superior e mais velhas que as superfícies situadas em 
posição inferior; d) é mais velha aos depósitos sobre elas; e) é mais jovem do que qualquer estrutura que a corte.

\subsection{Relações solo-paisagem na Depressão Periférica Paulista}

A Depressão Periférica Paulista é uma área "sui generis" e destaca-se pelas características geomorfológicas diferenciadas no Estado de São Paulo. ALMEIDA (1964) descreve a Depressão Periférica como sendo uma área rebaixada pela erosão entre as terras altas do Planalto Atlântico e as cuestas basálticas.

Talvez uma das primeiras referências sobre as superfícies de erosão da região de Piracicaba foi feita por BARTHELMESS (1958) num estudo abrangente sobre esta região. Neste trabalho a autora chama a atenção para as cotas de $600 \mathrm{~m}$ que envolvem a zona de Piracicaba, mas encontrou também resíduos de uma superfície de erosão de altitude superior a $600 \mathrm{~m}$. A esse relevo residual a autora correlacionou o "ciclo sul americano", enquanto que a maior parte da Zona de Piracicaba apresenta níveis correspondentes ao "ciclo velhas" de KING (1956).

Segundo PENTEADO (1976) em determinada época geológica toda a área da Depressão Periférica foi sujeita a processos de aplainamento generalizado que arrasaram seu relevo, subnivelando seus interfluvios entre as cotas 600 e $700 \mathrm{~m}$, constituindo uma superfície de erosão entre as bacias do Tietê e do Piracicaba. Esse evento tanbem foi relatado por ALMEIDA (1964).

De acordo com PENTEADO (1976) a superfície Rio Claro (Neogênica II) está entre as cotas 630 e $600 \mathrm{~m}$ e sobre a formação Rio Claro (neocenozóico) de BJONBERG \& LANDIM (1966) que por sua vez repousa sobre o grupo Passa Dois (formação Corumbataí). Esta descrição assemelha-se com a área de estudo com a diferença de que a cobertura neo-cenozóica está sobre a formação Pirambóia.

ROSS (1991) cita que a superfície Neogênica de De Martonne, é considerada como sendo os terrenos que nivelaram-se entre 800 a $900 \mathrm{~m}$, compreende trechos da Bacia do Vale do Paraíba, do Alto Tietê, projetando-se ligeiramente inclinada para oeste, correspondendo aos topos das colinas da Depressão Periférica, o que não está de acordo com PENTEADO (1976).

PENTEADO (1976) chama atenção ainda no aspecto geomorfológico geral de toda a Depressão Periférica para a presença de níveis intermediários entre o topo 
aplainado das colinas e o assoalho $\mathrm{p}$; ano das várzeas. Esses níveis se apresentam em forma de 2 ou 4 patamares, frequentemente recoberto por cascalheiras indicando fases sucessivas de aplainamento lateral e de entalhe. Este trabalho é importante pelo detalhe com que caracteriza uma área da depressão, situada em Rio Claro, e pela proximidade com o local desta pesquisa. A autora apresenta um esquema das superfícies e níveis de erosão na bacia de sedimentação de Rio Claro.

No modelo de BIGARELLA et al. (1965b) a superficie rio Claro corresponde provavelmente ao pediplano Pd1 ou ao pedimento $\mathrm{P} 3$, e a formação Rio Claro seria seu depósito correlato. Quanto a forma de deposição desta formação, MELO \& PONÇANO (1983) discutem quanto ao seu ambiente fluvial ou na forma de movimento de massa, ou seja, coluvial, em período semi-árido por ocasião da pedimentação, mas CRISTOFOLETTI (1983) sugere que estes depósitos superficiais sejam de origem coluvial.

Vários trabalhos sobre relações solo-paisagem foram realizados na depressão periférica paulista. LEPSCH (1975) estudou uma topossequência de Oxisol e Ultisol e investigou as mudanças morfológica dos solos, nesta topossequência foram separadas três superficies geomórficas.

DEMATTÊ \& HOLOWAYCHUK (1977) estudaram os solos desde a serra de São Pedro até o Rio Piracicaba e separaram seis superfícies físiográficas, usando critérios diferentes dos de DANIELS (1971).

LOBO (1984) identificou seis superfícies fisiográficas na região de Piracicaba, numa topossequência com uma cobertura pedimentar de textura média no topo seguida de rochas básicas até o rio Piracicaba.

COOPER et al. (1993) ativeram-se ao estudo detalhado de uma catena de solos originados de rochas básicas em uma encosta cujas porções que compõe essa vertente foram identificadas.

VIDAL-TORRADO (1994) encontrou cinco superfícies geomórficas no distrito de Tupi em Piracicaba, trabalhando numa área com uma cobertura neocenozóica e sedimentos da formação Itararé e formação Tatuí.

VIDAL-TORRADO (1989) estudou detalhadamente topossequência de solos desenvolvidos sobre um mesmo material de origem, na borda do Planalto Atlântico, através de parâmetros mensuráveis da paisagem, assim como a mineralogia e 
micromorfologia dos solos. Neste estudo porém o autor trabalhou com a segmentação da vertente, além da separação de surperficies.

COELHO (1994) estudou as relações solo-relevo numa encosta com transição arenito-basalto, na região das cuestas basálticas, e identificou três segmentos geomorfológicos distintos. Estes dois últimos trabalhos, embora não tenham sido realizados na Depressão Periférica Paulista, também são bons exemplos de estudos sobre relações solo-paisagem.

\subsection{Importância de estudos sobre relações solo-paisagem}

Muitas das soluções para problemas de pedologia dependem do conhecimento dos fatores e processos que interferem na formação dos solos, e de como estes estão se relacionado e atuando no sistema. Neste contexto os estudos geomorfológicos aliados a estudos pedológicos auxiliam enormemente a compreensão da dinâmica de formação dos solos.

DANIELS (1988) expressa sua preocupação em relação à tendência da pedologia atual questionando o uso intenso de análises de laboratório em detrimento às observações de campo que é o lugar onde o pedólogo deve procurar encontrar a maioria das respostas de questões sobre pedologia, geomorfologia e estratigrafia para melhor compreender as relações solo-paisagem e realizar amostragens representativas de modo a permitir uma extrapolação precisa dos dados. BICKI \& TANDARICH (1989) e JACOB \& NORDT (1991) concordam com as afirmações de Daniels e também enfatizam a importância dos trabalhos de campo nos estudos das relações solo-paisagem.

BIRKELAND (1984) refere-se a íntima relação que existe entre pedologia, geomorfologia e geologia, evidenciada pela ocorrência de depósitos coluviais e aluviais na base dos vales e rios, uma vez que o processo erosional do relevo dificulta o isolamento do material de origem dos demais fatores de formação do solo. Este fato demonstra que os sistemas pedológicos e geomorfológicos são dinâmicos, e reforça a idéia de que os solos não podem ser estudados isoladamente dos sistemas geomorfológicos dos quais elas são parte integrante.

No Brasil, trabalhos relacionando solos, material de origem e geomorfologia foram realizados por BENNEMA et al., (1962); LEPSCH \& BUOL, (1975); AZOLIN et al., (1975); RODRIGUES \& KLANT, (1978); PEREZ FILHO, 
(1980); MODENESI (1983) e CARMO et al. (1984) e com maior ênfase nas relações solorelevo QUEIROZ NETO \& MODENESI (1973), LEPSCH et al. (1977), LOBO (1984 ), MARQUES Jr. (1984 ), VIDAL-TORRADO (1992), RIZZO (1991), COOPER et al. (1993) e VIDAL-TORRADO (1994).

Para utilizar de forma adequada os modelos de relações solo paisagem para predições de campo é necessário visualizar a paisagem em termos do conceito de catena (HALL, 1983). Assim, os estudos das interações entre solos e os fatores do relevo são muito importantes para o entendimento do comportamento dos solos, e são de grande utilidade para a compreensão da pedogênese e para auxílio de levantamentos pedológicos de modo geral.

Segundo HALL \& OLSON (1991) historicamente, o uso de modelos de relações solo-paisagem mostra que a paisagem é previsivel porque ela tem um componente de variabilidade não casual. Esta propriedade pode ser usada para prever a ocorrência de solos na paisagem se a metodologia tanto para para descrever como para quantificar os processos que governam o desenvolvimento da paisagem for bem entendida. As bases para o entendimento dos solos e das paisagens estão nos conceitos de Davis e Penck e aqueles de Milne, King e Ruhe cujos modelos dão um importante papel aos processos de formação de vertentes.

Uma das principais aplicações das relações solo-paisagem é em levantamentos pedológicos, uma vez que diminuem o número de amostras a serem coletadas tornando-os menos onerosos e também mais rápidos pois evita a ida constante ao campo. Uma vez bem compreendidas as relações e diferenças entre os solos, geomorfologia, estratigrafia e hidrologia os levantamentos pedológicos se tornam mais precisos e o trabalho de campo torna-se eficaz, pois muitas propriedades dos solos possuem padrões de ocorrência na paisagem (DANIELS, 1971).

VREEKEN, (1984) comenta sobre o conceito de pedocronologia, e define-o como sendo a sequência de mudanças no solo ao longo do tempo em uma dada paisagem. Análises estratigráficas e paleogeomórficas integradas em sistemas solopaisagem podem oferecer informações sobre a história da paisagem e proporcionar uma base racional para promover estudos pedológicos e de relações solo-geomorfologia.

As unidades de mapeamento de solos são baseados em uma variedade de propriedades da paisagem (SWANSON, 1990). Entretanto, o sistema formal de classificação, que é usado para descrever e definir essas unidades de mapeamento, é 
baseado apenas nas propriedades dos solos. $\mathrm{O}$ autor sugere o desenvolvimento de um sistema que integre propriedades da paisagem e propriedade dos solos para fins de mapeamento e também para fins de manejo de solos.As relações que existem entre os solos e a paisagem permite o uso de unidades de mapeamento de solos concebidas a partir destas relações, diferentes das unidades tradiciomais de mapeamento. Estas unidades são baseadas em aspestos morfológicos do relevo.

Neste contexto, a classificação brasileira de solos utiliza em sua nomenclatura termos que definem o relevo e situam o solo na paisagem local (SNLCS, 1986), que é o caso do uso de fases de relevo.

Segundo BRIGGS \& SHISHIRA (1985) o uso de unidades de mapeamento geomorfologicamente definidas tem ganho grande aceitação nas pesquisas sobre levantamento de solos. Argumenta-se que a vantagem de tais unidades inclui o fato de que elas são prontamente identificáveis através de fotografias aéreas e se repetem na paisagem. A desvantagem, entretanto, está na homogeneidade desta unidade em relação a alguns atributos dos solos, que em determinadas condições requerem uma densidade de amostragem muito alta para atingir um nível de precisão razoável.

Relações solo paisagem também podem ser usados para relacionar, solos e vegetação. EMMERICH, (1990) estudou as relações entre as formas de relevo, o cerrado e solos em diferentes regiões do Brasil.

A produtividade das terras pode ser analisada em termos geomorfológicos. ONSTAD et al. (1985) estudando uma catena com 5 unidades de solos, observaram que a posição do solo na paisagem tem relação com a produtividade. A pesquisa revelou que mudanças no índice de produtividade considerando apenas as unidades de mapeamento podem omitir informações a menos que a posição dessas unidades na paisagem sejam levadas em consideração. As relações solo-paisagem podem dar mais informações, como uma unidade básica, para determinar as mudanças na produtividade, como resultado da erosão do solo, ao longo do tempo.

Os trabalhos de relações solo-paisagem usualmente utilizam métodos qualitativos para comparação da homogeneidade das superfícies geomórficas em termos de solos, (PERES FILHO et al. (1980); LEPSCH, (1977); BERG et al., (1987); VIDALTORRADO, (1994), UBERTI \& KLAMT, (1984) geralmente descrevendo e comentando tabelas de distribuição de solos em superfícies, ou discorrendo sobre a distribuição dos solos nas superfícies geomórficas de forma global. 
Entretanto trabalhos que quantificam o conceito de homogeneidade são aplicados em botânica, como é o caso de números índices relacionados a ocorrência ou frequência de um determinado fator que são usados em fitossociologia, como é o caso do índice do valor de importância (IVI) que utiliza os parâmetros frequência e cobertura de cada espécie na formação vegetal. Ouro índice bastante usado é o índice do valor de cobertura (IVC) que é mais especificamente usado para avaliar a cobertura, ou seja, a área que cada espécie ocupa medida pela projeção de sua copa no terreno RODRIGUES (1988).

Segundo MURRAY (1985) um número índice é uma medida estatística idealizada para mostrar as variações de uma variável, ou de um grupo delas, correlacionadas no tempo, à localização geográfica e a muitas outras características.

Para CHRISTOFOLETTI (1994) o conhecimento geomorfológico surge como instrumental utilizado e inserido na execução de vários trabalhos de planejamento, tal como planejamento de uso de solo rural e urbano, obras de engenharia, planejamento ambiental, pequisa de recursos naturais e recuperação de áreas degradadas.

Praticamente todo trabalho que estuda a distribuição dos solos na superficie terrestre emprega algum conceito geomorfológico. Provavelmente o mais importante é entender que diferentes partes de uma paisagem podem ter diferentes histórias. 


\section{MATERIAIS E MÉTODOS}

\subsection{Localização da área}

A área escolhida para este estudo localiza-se na Depressão Periférica Paulista, no município de Piracicaba - SP, na microbacia hidrográfica do ribeirão Marins.

Situa-se entre as latitudes $22^{\circ} 47^{\prime} \mathrm{S}$ e $22^{\circ} 49^{\prime}$ e longitudes $48^{\circ} 47^{\prime} \mathrm{W}$ e $48^{\circ} 48^{\prime} \mathrm{W}$ (Figura 1), constituindo uma faixa de 456ha, representativa em termos de solos e fisiografia desta microbacia, estendendo-se desde o divisor de águas até a margem direita do ribeirão Marins, que é afluente do rio Piracicaba (Figura 2). 


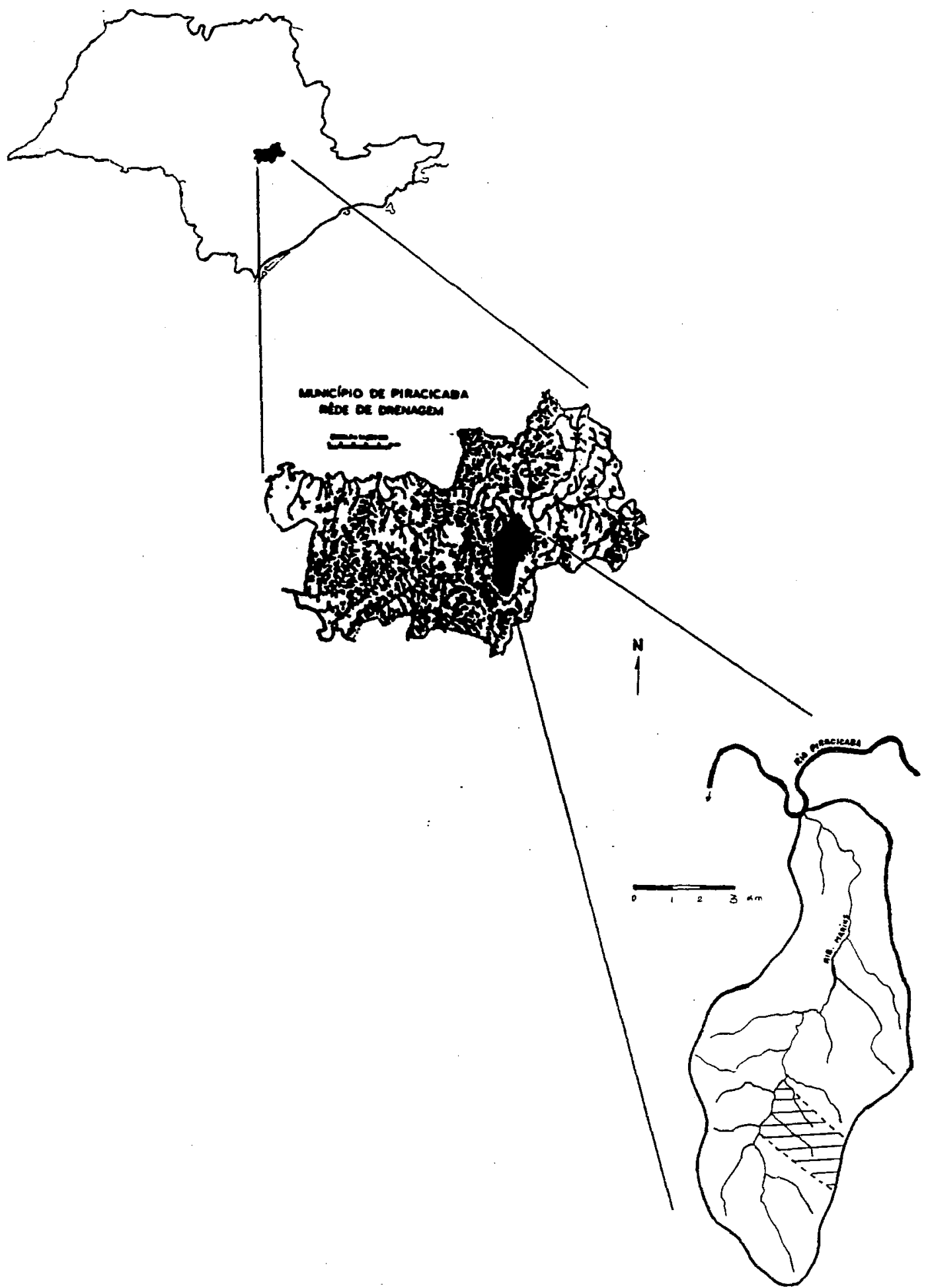

Figura 1. Localização da área de estudo no Estado de São Paulo. 


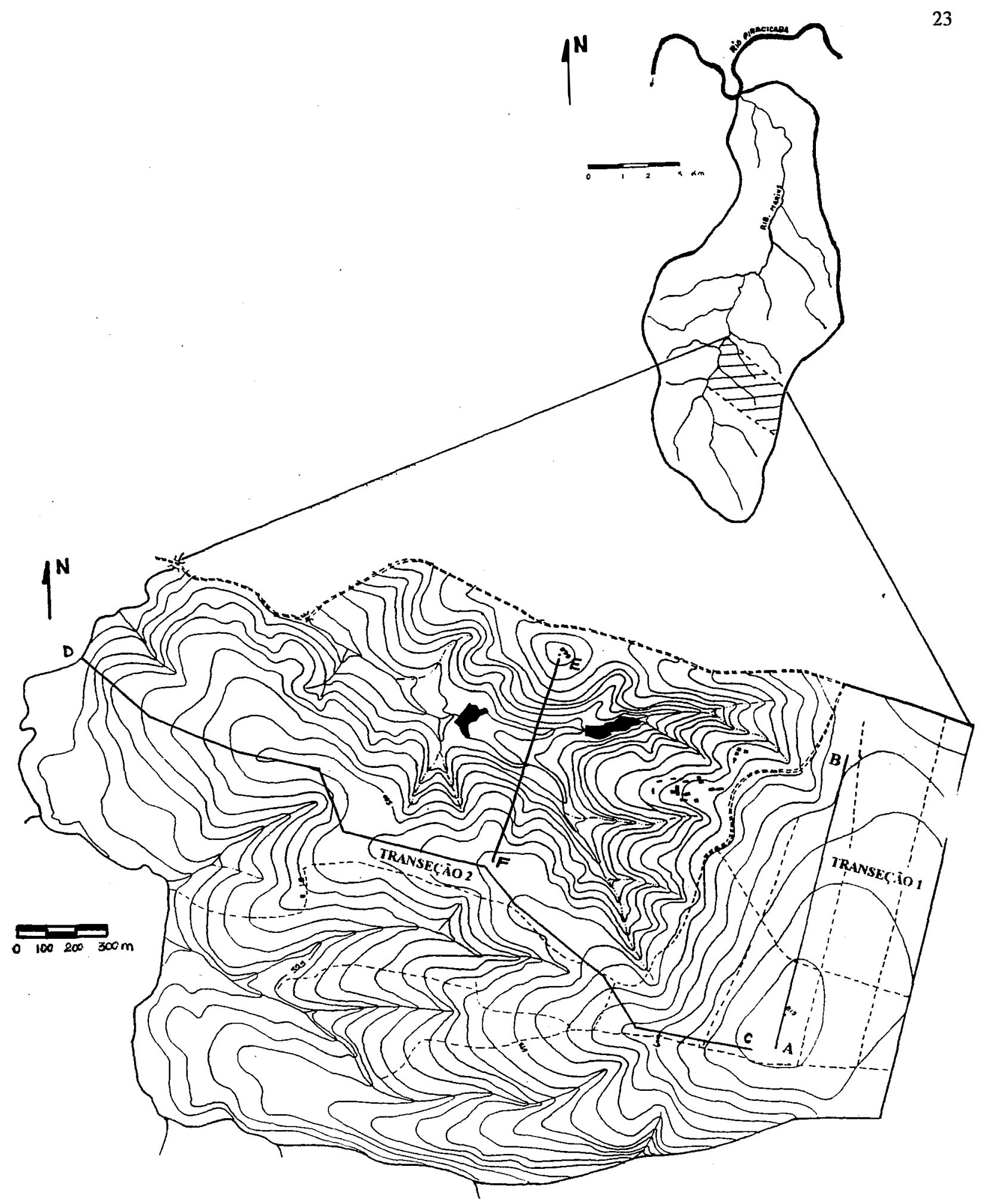

Figura 2: Mapa planialtimétrico da área de estudo, sua localização em relação a microbacia do ribeirão Marins, mostrando a posição das transeções 1 e 2, e dos cortes $\mathrm{AB}, \mathrm{CD}$ e EF. 


\subsection{Clima}

O clima da região de Piracicaba é classificado por Köppen, como sendo do tipo Cwa, mesotérmico úmido, subtropical com inverno seco, em que a temperatura do mês mais frio não excede $18^{\circ} \mathrm{C}$ e a do mês mais quente é maior que $22^{\circ} \mathrm{C}$ (BRASIL, 1960). O regime térmico do solo é hipertérmico segundo OLIVEIRA et al., (1976). Para solos rasos, como é o caso dos litólicos o regime térmico pode ser ústico. A Figura 3 mostra o balanço hídrico da região de Piracicaba.

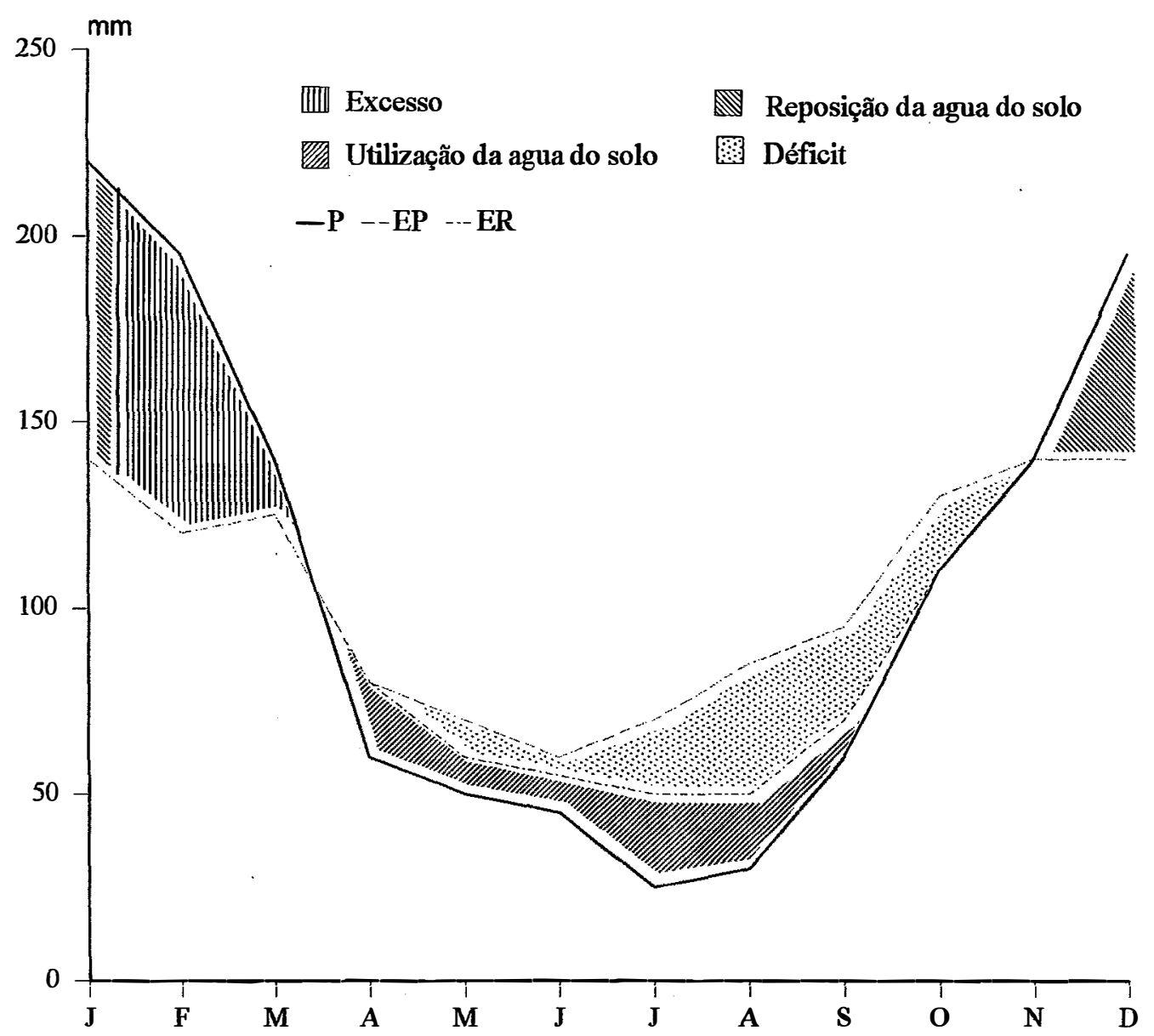

Figura 3: Balanço hídrico segundo Thornwaite da região de Piracicaba. 


\subsection{Geologia}

A área de estudo está inserida na bacia sedimentar do Paraná. Segundo IPT (1981) a maior parte do Estado de São Paulo acha-se incluida nesta bacia, que é uma unidade geotectônica estabelecida sobre a plataforma Sul-Americana a partir do devoniano inferior. A persistente subsidência desta bacia permitiu a acumulação de grande quantidade de sedimentos.

A coluna estratigráfica da área de estudo é representada por uma cobertura cenozóica, sedimentos dos grupos São Bento e Passa Dois, estes dois últimos representados respectivamente pelas formações Pirambóia e Corumbataí.

A formação Pirambóia é caracterizada por depósitos fluviais incluindo arenitos finos a médios avermelhados, sílticos argilosos com estratificação cruzada ou plano paralela, mas predomina a estratificação plano-paralela, destacada pela alternância de lâminas mais ou menos ricas em argila ou silte. Níveis de folhelhos e arenitos argilosos de cores variegadas e raras intercalações de natureza argilo-arenosas podem ser encontradas (IPT, 1981).

A formação Corumbataí é caracterizada por depósitos marinhos com estratificação plano paralela, predominando siltitos, arenitos finos em parte concrecionados por calcário e sílex, de coloração vermelha arroxeada na parte inferior e esverdeada na base (IPT, 1981).

\subsection{Relevo e geomorfologia}

De acordo com IPT (1981) a área de estudo está localizada na depressão periférica paulista, na zona do Médio Tietê. Segundo Ab'SABER (1969) esta depressão tem a forma de um corredor de topografia colinosa de aproximadamente $50 \mathrm{Km}$ de largura, nitidamente embutido entre a cuesta do Planalto Ocidental e as elevações das rochas cristalinas do Planalto Atlântico.

A zona do Médio Tietê, segundo ALMEIDA (1964) compreende a área da Depressão Perifrica que é drenada para o rio Tietê, segundo os divisores de águas dos rios Mogi-Guaçu e Paranapanema. Esta Zona é constituida por sedimentos com área expressiva de intrusões de rochas básicas. A inclinação das camadas sedimentaares fez com 
que se destacassem, sob formas cuestiformes, rochas mais resistentes como os tilitos, as rochas da formação Irati, e estruturas silicificadas da formação Corumbataí.

Segundo IPT (1981) na depressão periférica paulista, predominam as colinas amplas, colinas médias e os morrotes alongados, e na zona do Médio Tietê predominam relevos de colinas amplas e colinas médias.

A área apresenta relevo suavemente ondulado no topo. A partir daí em direção ao ribeirão Marins o relevo torna-se ondulado a fortemente ondulado. As colinas são estreitas formando esporões com lançantes longos, quase paralelos entre si, orientados no sentido do topo para o ribeirão. $O$ declive nessas colinas está em torno de 5 a $10 \%$ e o comprimento de rampa varia entre 500 a 1000m. Estes lançantes são separados por vales escarpados em forma de "V", onde a declividade é superior a $30 \%$.

Para melhor observar o relevo, o mesmo foi representado através de um bloco diagrama, confeccionado através do programa Surf (Golden Software). O bloco diagrama foi contruido a partir de um mapa palnialtimétrico na escala 1:10.000, sobre o qual foi colocado um papel vegetal quadriculado. Neste papel vegetal plotou-se um sistema de eixos $\mathrm{x}$, y de tamanho suficiente para engloḅar a área de estudo e de modo que seus limites ficassem tangentes a esses eixos. Em cada linha do eixo y, anotou-se o valor da cota e a coordenada $(\mathrm{x}, \mathrm{y})$ que intercepta cada linha de cota. A partir daí construiu-se uma tabela $\mathrm{x}, \mathrm{y}, \mathrm{z}$ que é utilizada pelo programa surf para construção do bloco diagrama.

\subsection{Solos}

A área apresenta uma seqüência de solos desde os mais profundos e desenvolvidos até os mais jovens e imaturos. Nas cotas mais elevadas os solos são mais intemperizados e profundos, nas cotas intermediárias os solos possuem mudança textural abrupta entre os horizontes E e B e finalmente, nas cotas inferiores, os solos são pouco profundos e menos desenvolvidos.

Na área estudada, OLIVEIRA \& PRADO (1989) observaram, no levantamento semi-detalhado de solos do Estado de São Paulo, quadrícula de Piracicaba, a presença de Latossolo Vermelho-Amarelo textura média, denominado Unidade Laranja Azeda, Podzólico Vermelho-Amarelo abrupto, denominado Unidade Serrinha, e Litólicos indiscriminados do grupo Passa Dois na área de estudo. 


\subsection{Uso atual}

A área de estudo, é ocupada por pastagens, eucalipto e cana-de-açúcar, sendo que esta última cultura abrange a maior parte da área, principalmente devido à proximidade com a Usina Santa Helena.

A cana-de-açúcar é cultivada nas áreas de menor declividade, enquanto que as pastagens ocupam as encostas mais íngremes e são destinadas ao gado de corte. $\mathrm{O}$ eucalipto encontra-se em pequenas áreas mais elevadas e em alguns fundos de vales. A vegetação original quase inexiste, sendo que alguns remanescentes são encontrados em algumas grotas e nas margens do ribeirão Marins.

\subsection{Método de campo}

O trabalho de campo se constituiu basicamente das seguintes etapas:

(1) amostragem das transeções e tradagens profundas; (2) mapeamento dos solos; (3) mapeamento das superfícies geomórficas; (4) mapeamento geológico.

\subsubsection{Transeções}

Foram estabelecidas duas transeções para amostragem sistemática dos solos . Uma delas foi locada próximo ao divisor de águas da bacia, e a outra encosta abaixo desde o topo até o ribeirão Marins. Em ambas transeções a coleta de amostras se deu em pontos regularmente espaçados a cada $50 \mathrm{~m}$. As amostras foram retiradas utilizando-se trado tipo holandês, anotando-se a cor do solo com a carta de cores de MUNSELL e em seguida foram encaminhadas ao laboratório para análises química e granulométrica de rotina.

A primeira transeção, localizada no topo, possui 20 pontos. Foram coletadas amostras deformadas representativas da camada superficial $(0-20 \mathrm{~cm})$ e da camada subsuperficial $(60-80 \mathrm{~cm})$ em todos os pontos, uma vez que os solos nesta porção da paisagem mostraram-se profundos.

A segunda transeção possui 52 pontos e o procedimento de coleta de amostras foi feita de forma análoga à primeira, com a ressalva de que a camada subsuperficial só foi coletada quando existente, devido à presença de solos rasos. 
Essa transeções foram realizadas com o objetivo de verificar a variação lateral das unidades de solos.

\subsubsection{Mapeamento das superfícies geomórficas}

A separação das superfícies geomórficas seguiu os critérios de DANIELS et al. (1971). Para a realização do mapa de superficies o material básico utilizado foram fotografias aéreas na escala aproximada de 1:25.000 (IBC-GERCA, 1972).

Através de fotointerpretação. foram separadas 5 superficies geomórficas, cujos limites foram marcados na própria fotografia aérea e posteriomente transferidos para carta planialtimétrica escala 1:10.000 através do "aeroscathmaster".

As superficies delimitadas inicialmente por fotointerpretação, foram verificadas no campo numa época em que a cana-de-açúcar estava ainda nos estádios iniciais de desenvolvimento, permitindo dessa forma a visualização total da área.

De acordo com DANIELS et al. (1971) quando uma quebra de relevo é devida a um controle litológico, esta quebra não caracteriza a separação de das superficies distintas. Como na área de estudo o sílex presente na formação Corumbataí é um material controlador do relevo, tomou-se o cuidado para que esse controle litológico não fosse identificado como uma superfície geomórfica distinta.

\subsubsection{Mapeamento geológico}

Para conhecimento da geologia assim como da estratigrafia local, foi feito um mapa geológico da área.

Durante o levantamento de solos, afloramentos rochosos foram visitados para verificação da geologia, não só na área estudada como também em outros locais da microbacia do ribeirão Marins.

Tentou-se separar as formações Pirambóia, Corumbataí e a cobertura neo-cenozóica existente no topo. Procurou-se também observar a presença de possíveis falhamentos geológicos através da observação da continuidade topográfica dos diferentes níveis sedimentares, haja vista a importância deste fenômeno na compreensão da posição relativa dos solos na paisagem. 
O mapa geológico foi compilado em mapa planialtimétrico na escala $1: 10.000$.

\subsubsection{Mapeamento de solos}

O mapeamento de solos foi realizado em nível detallhado. Foram utilizados como base catográfica mapas planialtimétricos na escala 1:10.000 do IGC (Instituto Geográfico e Cartográfico), e fotografias aéreas na escala 1:25.000 (IBCGERCA, 1972).

Inicialmente foi realizado uma visita a área com o objetivo de reconhecimento preliminar dos principais tipos de solos lá existentes.

O levantamento foi feito por caminhamento em toda a área. Dessa forma quase todos os limites das unidades de solos foram determinados no campo e demarcados em mapa planialtimétrico na escala 1:10.000. A fotointerpretação foi usada como apoio ao trabalho de campo.

\subsubsection{Amostragem de solos}

A amostragem de solos foi ralizada segundo três métodos:

(1) tradagens ao acaso; (2) trincheiras e barrancos; (3) tradagens profundas

A amostragem ao acaso teve como objetivo obter dados para a caracterização quantitativa das unidades de solos e para análise estatística das correlações entre as superficies geomórficas, unidades de solos e geologia.

Esta amostragem foi sendo realizada concomitantemente ao mapeamento de solos, o que permitiu um bom detalhamento dos seus limites. Foram coletadas amostras representativas da camada superficial $(0-20 \mathrm{~cm})$ e da camada subsuperficial $(60-80 \mathrm{~cm})$ quando possível ou quando existente, para isso utilizou-se trado tipo holandês.

Para efeito de validade de significância estatística, procurou-se amostrar no mínimo 8 pontos por superfície geomórfica.

Perfis completos de solos foram descritos e amostrados em trincheiras e barrancos para caracterização das unidades de solos. A descrição dos perfís seguiu as 
normas da Sociedade Brasileira de Ciência do Solo (SBCS, 1984) e são apresentadas em apêndice. Foram coletadas amostras deformadas dos horizontes que foram encaminhadas ao laboratório para análises químicas e granulométricas de rotina.

No fundo de uma trincheira localizada no topo da área foi realizada uma tradagem profunda a partir do fundo dessa trincheira. Esta tradagem totalizou 7,0m de profundidade e teve como objetivo verificar a relação estratigráfica entre a cobertura neocenozóica do topo e os sedimentos das cotas inferiores. Foi coletada uma amostra a cada $50 \mathrm{~cm}$ de profundidade para determinações de laboratório. Apesar da grande profundidade, não foi verificada a presença de saprolito ou qualquer material de alteração in situ. A constatação do material de origem do solo deste local foi limitada pelo comprimento do trado que não permitiu ir além dos $7,0 \mathrm{~m}$ de profundidade.

Uma segunda tradagem profunda foi feita numa vertente na cota $545 \mathrm{~m}$, para verificar qual o material de origem dos solos deste local. Neste ponto a tradagem alcançou 3,0m de profundidade, quando foi verificado a presença de saprolito do arenito. Como o objetivo desta tradagem foi apenas verificar o tipo de substrato geológico, julgou-se desnecessária a coleta de material para análise de laboratório, sendo analisado apenas textura e cor do solo.

\subsection{Métodos de laboratório}

As amostras coletadas para análise foram encaminhadas ao laboratório do Departamento de Ciência do Solo da ESALQ-USP.

As determinações foram feitas com terra fina seca ao ar (TFSA), ou seja amostras destorroadas e passadas em peneira de $2 \mathrm{~mm}$ de abertura de malha.

\subsubsection{Análises quimicas}

As determinações foram feitas segundo RAIJ et al. (1987).

- $\mathrm{pH}$ em $\mathrm{H}_{2} \mathrm{O}$ e em $\mathrm{KCl} 1 \mathrm{~N}$ : Determinação potenciométrica após três horas de repouso com relação solo-líquido 1:2,5. 
- Carbono orgânico: Determinação através de método colorimétrico. Oxidação da matéria orgânica do solo por solução de dicromato de sódio em ácido sulfúrico a frio.

- Fósforo: Determinado a partir de extração por resina trocadora de íons.

- Bases trocáveis $\left(\mathrm{Ca}^{2+}, \mathrm{Mg}^{2+}, \mathrm{K}^{2+}, \mathrm{Na}^{+}\right)$: Obtidos por extração por resina trocadora de íons.

- Soma de bases: $\mathrm{S}=\mathrm{Ca}^{2+}+\mathrm{Mg}^{2+}+\mathrm{K}^{2+}+\mathrm{Na}^{+}$meq/100g TFSA

- Saturação por bases: V\% $=(\mathrm{S} / \mathrm{T}) \times 100$

- Acidez titulável $\left(\mathrm{H}^{+} \mathrm{Al}^{3+}\right)$ : determinação através da solução tampão SMP mediante curvas de correlação entre valores de pH da solução tampão e valores de acidez potencial determinados em solos pelo método do acetato de cálcio.

- Alumínio trocável $\left(\mathrm{Al}^{3+}\right)$ : Obtido por extração por agitação de $5 \mathrm{~g}$ de TFSA em 100ml de cloreto de potássio $1 \mathrm{~N}$ e titulação com $\mathrm{NaOH} 0,1 \mathrm{~N}$, usando fenolftaleina como indicador.

- Saturação por Alumínio: $\mathrm{Al} \%=\mathrm{Al}^{3+} /\left(\mathrm{S}+\mathrm{Al}^{3+}\right)$

- Capacidade de troca de cátions: $\mathrm{T}=\mathrm{S}+\mathrm{H}+\mathrm{Al}^{3+}$ meq/100g TFSA

\subsubsection{Análises físicas}

- Granulometria: foi determinada na TFSA, o método usado foi o do densímetro, após 16 horas de agitação, tendo como dispersante mistura de hidroxido de sódio e hexametafosfato de sódio (CAMARGO et al., 1986) durante 16 horas.

\subsection{Cruzamento das informações}

As informações básicas obtidas com os levantamentos de superficies geomórficas, geologia e solos foram compilados em mapas e depois digitalizados para serem processados em computador.

Esses mapas temáticos foram feitos sobre a mesma base cartográfica, ou seja, mapa planialtimétrico na escala 1:10.000. Para permitir o cruzamento dessas informações cada unidade de informação ou "pixel" foi geograficamente referenciada de modo a cada pixel ter a mesma posição geográfica em todos os mapas. A sobreposição dos 
mapas foi realizado com o programa para microcomputador "GMAP" para manipulação de mapas temáticos de SPAROVEK \& VAN LIER, (1993). A confecção gráfica dos mapas foi realizada através do programa IDRISI.

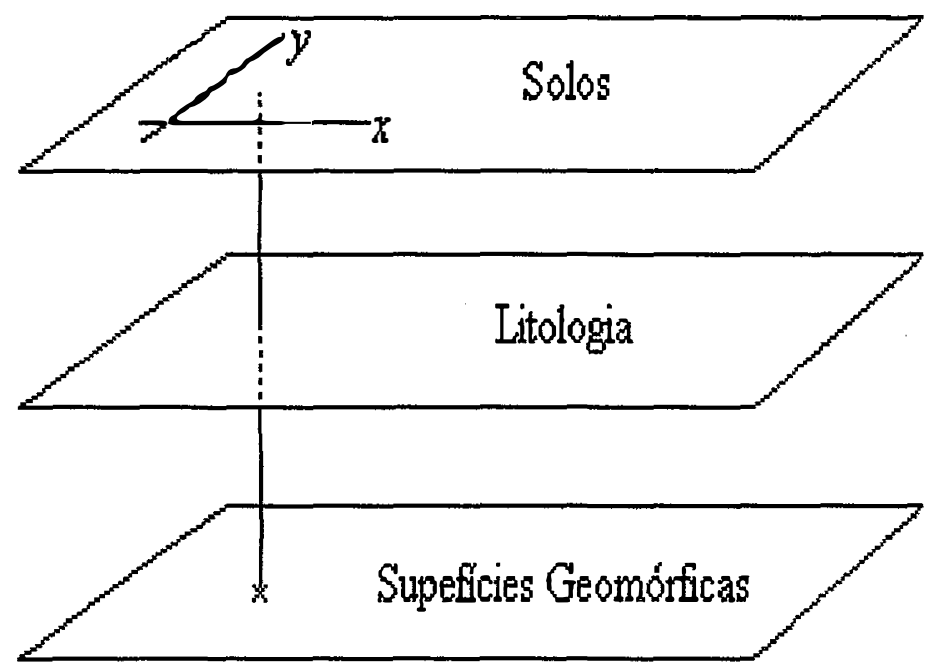

Figura 4: Esquema da metodologia para cruzamento das informações dos mapas temáticos. Cada ponto ou "pixel" possui coordenadas $\mathrm{x}$, y que são as mesmas em cada um dos mapas.

\subsection{Análises estatísticas}

Foi realizado um teste de comparação de médias entre as superfícies geomórficas usando-se alguns atributos químicos e físicos dos solos, com a finalidade de verificar a existência de diferenças entre as superficies quanto aos atributos analisados. Utilizou-se o teste Tukey com nível de significância de 5\%, por meio do programa estatístico "Statgrafics". 


\section{RESULTADOS E DISCUSSÃO}

\subsection{Geologia}

A geologia da área é composta por uma formação superficial da era cenozóica, pelo grupo São Bento representado por arenitos da formação Pirambóia e pelo grupo Passa Dois representado pelos siltitos, argilitos, folhelhos e sílex da formação Corumbataí. Essa geologia está representada no mapa da Figura 5.

Existem na área pelo menos dois depósitos superficiais, a cobertura neo-cenozóica e os depósitos coluviais no fundo dos vales. Depósitos de encosta, ou colúvios de encosta, não foram encontrados. Os depósitos superficiais e as formações geológicas estão ilustrados na coluna estratigrafica (Figura 6).

\begin{tabular}{|c|c|}
\hline Alúvios-colúvios & Quaternário - holoceno \\
\hline Cobertura neo-cenozóica & Neo-cenozóico - terciário \\
\hline Formação Pirambóia & Mesozóico - triássico \\
\hline Formação Corumbataí & Permiano superior \\
\hline
\end{tabular}

Figura 5: Coluna estratigráfica da área de estudo. 


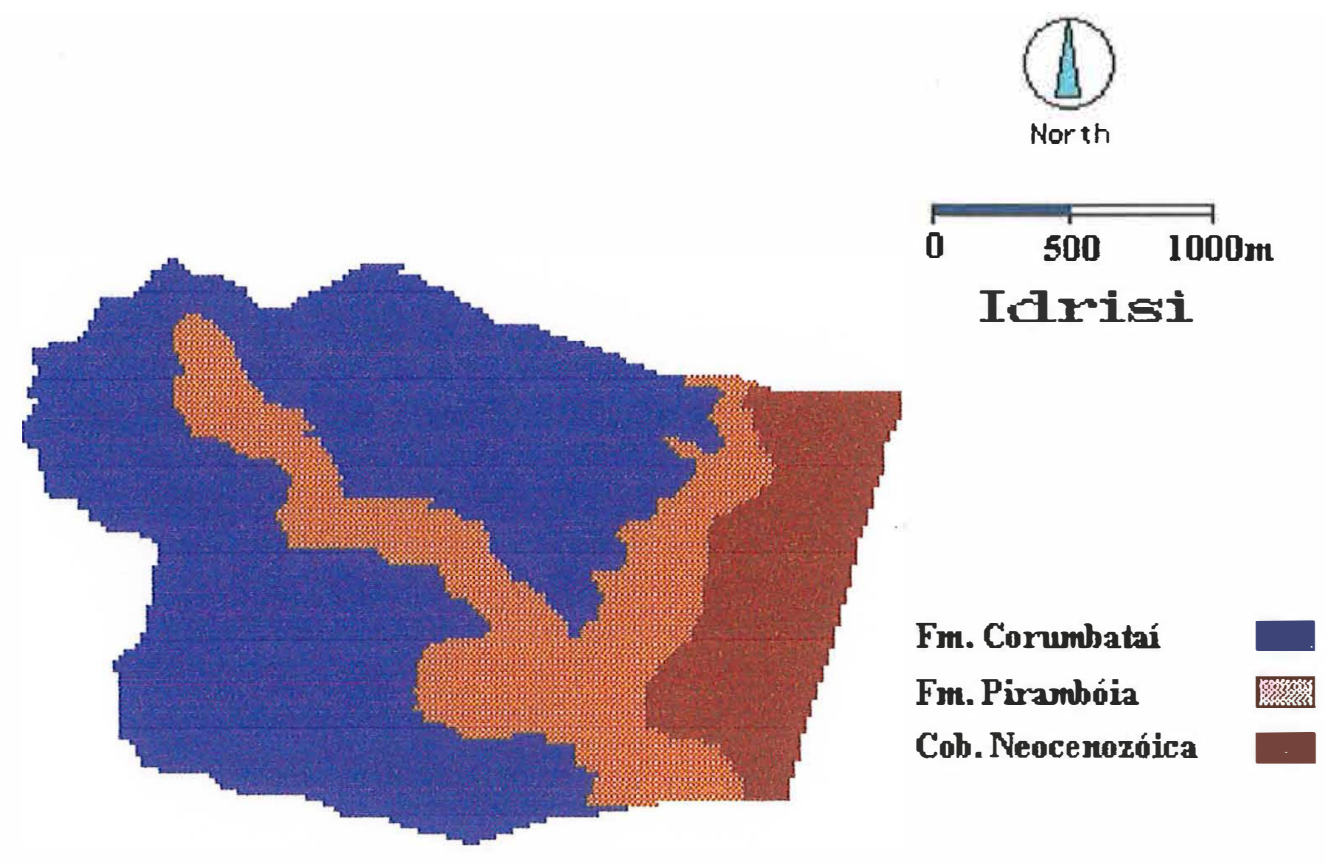

Figura 6: Mapa geológico da área de estudo

A área estudada é dominada por siltitos e folhellhos da formação Corumbataí, que ocupa mais da metade do seu total, seguido pela formação Pirambóia e pela cobertura Neocenozóica (Tabela 1). O estudo da distribuição espacial desses substratos geológicos é importante para a compreeensão da distribuição dos solos na paisagem.

A formação superficial localizada no topo, aqui tratada como cobertura neo-cenozóica, possui textura média, alta permeabilidade, cor avermelhada com 
matiz variando de $5 \mathrm{YR}$ e 2,5 YR e grande espessura. Neste local foi feita uma tradagem com 7,0m de profundidade, e até essa profundidade não foram encontradas linhas de pedras nem saprolito de arenito indicando que a espessura dessa cobertura é superior a 7,0 m.

BIGARELLA \& ANDRADE, (1965) e PENTEADO, (1974) citam que a essa coberturas estão associadas cascalheiras ou linhas de pedras basais, mas na área de estudo essas feições não foram encontradas.

Esta cobertura pode estar relacionada com a formação Rio Claro. Segundo BJORNBERG \& LANDIM (1966) nas partes mais altas da região de Piracicaba e São Pedro dominam sedimentos coluviais, arenosos, porosos e permeáveis muito espessos da formação Rio Claro.

OKA-FIORI \& CHRISTOFOLETTI (1983) verificaram que a formação Rio Claro assenta-se em grande parte sobre a formação Pirambóia ou Estrada Nova que está de acordo com a estratigrafia da área. Os autores concluem também que em Piracicaba, a grande maioria das formações superficiais é do tipo coluvial, enquanto que os depósitos aluviais estão restritos ao longo dos rios Piracicaba e Corumbataí. Estes depósitos denominados de sedimentos detríticos (CHRISTOFOLETTI \& PENTEADO, 1970) são na maioria das vezes constituidos por areias sem estruturação, sendo que podem ser muito similar às rochas vizinhas.

Tabela 1: Área de ocorrência das formações geológicas e depósitos superficiais e respectiva porcentagem em relação a área total.

\begin{tabular}{ccc}
\hline $\begin{array}{c}\text { Formações Geológicas e } \\
\text { Depósitos Superficiais }\end{array}$ & Área (ha) & $\begin{array}{c}\text { \% da área } \\
\text { total }\end{array}$ \\
\hline Corumbataí & 248,3 & 54,4 \\
Pirambóia & 122,5 & 26,9 \\
Cobertura neo-cenozóica & 67,9 & 14,9 \\
Alúvio-coluvios & 16,0 & 3,5 \\
\hline Total & $\mathbf{4 5 5 , 7}$ & $\mathbf{1 0 0}$
\end{tabular}


FULFARO \& SUGUIO (1974) também descrevem uma cobertura neo-cenozóica recobrindo os arenitos da formação Pirambóia.

$\mathrm{Na}$ área de estudo esta cobertura assenta-se sobre rochas da formação Pirambóia, mas num barranco escavado para uma olaria a cerca de $3 \mathrm{Km}$ desta área, em cota inferior, a mesma cobertura foi encontrada sobre a formação Tatui e Irati, provavelmente, e está separada desta por uma linha de pedras. Neste barranco a citada cobertura é um pouco mais argilosa, provavelmente devido a influência dos sedimentos argilosos da formação Corumbataí.

Partindo-se da área estudada em direção à Piracicaba ou seja rumo NE, este depósito torna-se argiloso e vermelho escuro. Isso deve-se provavelmente ao fato de que nesta região esta formação superficial recebe maior contribuição do material argiloso originado dos siltitos e argilitos provavelmente das formações Tatui e Irati sobre a qual está diretamente assentada, enquanto que na área de estudo este depósito assenta-se sobre sedimentos arenosos da formação Pirambóia, recebendo maior contribuição de areia.

O fato dessa cobertura estar sobre diferentes formações geológicas sugere que a mesma teve origem deposicional, caracterizando-se como pedissedimento, e está de acordo com PENTEADO, (1976) que atribui origem deposicional a esses topos planos situados entre as cotas 600 a 620m na Depressão Periférica. Sugere também que este depósito é mais recente que as duas formações geológicas subjacentes encontradas na área e reforça a idéia de aloctonismo deste material. Este fato é comentado por VIDALTORRADO (1994) que encontrou uma cobertura neo-cenozóica sobre diferentes formações geológicas em Tupi, distante aproximadamente $25 \mathrm{Km}$ da área estudada neste trabalho a qual correlaciona-se com a encontrada na área de estudo.

Abaixo desta cobertura neo-cenozóica encontram-se rochas da formação Pirambóia. Neste local ela não apresenta grande espessura situando-se entre as cotas 580 a 585m. No entanto em virtude de uma provável falha geológica esta formação também é encontrada numa vertente a aproximadamente $450 \mathrm{~m}$ de atitude.

Num barranco de estrada, de ocorrência isolada, encontrou-se entre a cobertura neo-cenozóica e o arenito da formação Pirambóia camadas de lamitos argilosos com colorações diferenciadas na massa do solo. A formação Pirambóia representa, por suas características litológicas e estruturais, depósitos de ambientes continental úmido admitindo pequenas lagoas esparsas (IPT,1981), que possibilitariam a formação localizada de lamitos. 
A formação Corumbataí ocorre logo abaixo da formação Pirambóia. Esta apresenta-se bastante espessa e aflora em vários locais, desde a cota $570 \mathrm{~m}$ até $490 \mathrm{~m}$ no ribeirão Marins.

Devido a sua variedade litológica (IPT, 1981), procurou-se a separação de fácies, na formação Corumbatá. No entanto essa separação não se fez necessária uma vez que na área a litologia dessa formação é predominantemente constituída por siltitos. Para VIDAL-TORRADO, (1994) a separação das litofácies das Formações Itararé e Tatuí foi importante, pois essas formações possuem rochas com texturas diferentes, que influenciam na textura dos solos delas originados.

A formação Corumbataí apresenta uma camada característica de sílex. $\mathrm{Na}$ área de estudo esta camada possui espessura variando em torno de 20 a $30 \mathrm{~cm}$ e ocorre de forma quase horizontal nas cotas 575 a $580 \mathrm{~m}$ e outra camada mais descontínua, na cota $530 \mathrm{~m}$. Esta bancada é um agente controlador da declividade do relevo devido a sua grande resistência à erosão. Nos locais onde o sílex ocorre em dois níveis, o relevo apresenta a forma de dois patamares na encosta.

Com o recuo das vertentes este sílex espalha-se na superfície por ação da gravidade. O sílex desta região apresenta vesículas amigdaloidais preenchidas com quartzo cristalizado constituindo drusas. A ocorrência de sílex com essas características também foi constatada no distrito de Artemis, onde a formação Corumbataí também é aflorante SPAROVEK et al. (1990). O sílex também apresenta-se esparso e espalhado na superfície plana de alguns interflúvios. Esta ocorrência pode estar relacionada com áreas deprimidas no terreno, devido à coalescência de vertentes. Esta depressão, embora suave, seria suficiente para permitir o afloramento do sílex em superfície.

Ainda com relação à formação Corumbataí, fósseis petrificados de troncos de árvores foram encontrados. Estes ocorrem preferencialmente nas cotas 520 a $530 \mathrm{~m}$, e estão espalhados pelo terreno, sendo que em alguns locais a concentração é maior. Segundo IPT, (1981) esta formação é rica em fósseis, e estes provavelmente são do Permiano. VIDAL-TORRADO (1994) também encontrou fósseis petrificados de troncos de árvores na formação Tatuí, no distrito de Tupi distante aproximadamente $30 \mathrm{~km}$ da área estudada, e classificou-os como possivelmente pertencentes ao filo Tracheophyta, da classe Pteridospermophyta. Provavelmente estes troncos sejam pertencentes a espécies diferentes, uma vez que os encontrados em Tupi são mais antigos que os encontrados na microbacia do ribeirão Marins. 
Numa encosta, onde foi realizada a topossequência 1, observou-se uma descontinuidade dos níveis topográficos entre o arenito e o folhelho (siltitos), sendo percebida uma falha normal, provavelmente de origem mezozóica, em um canal de drenagem onde ocorrera o abatimento do arenito situando-o em cotas abaixo de $545 \mathrm{~m}$ (Figura 7). A presença do arenito nesta cota, a primeira vista, contraria a afirmação de que a formação Pirambóia neste local possui pouca espessura. No entanto a presença de uma falha geológica nesta vertente explica tal questão, ou seja, a camada de arenito não aumenta de espessura, mas foi rebaixada em relação à área de sua principal ocorrência.

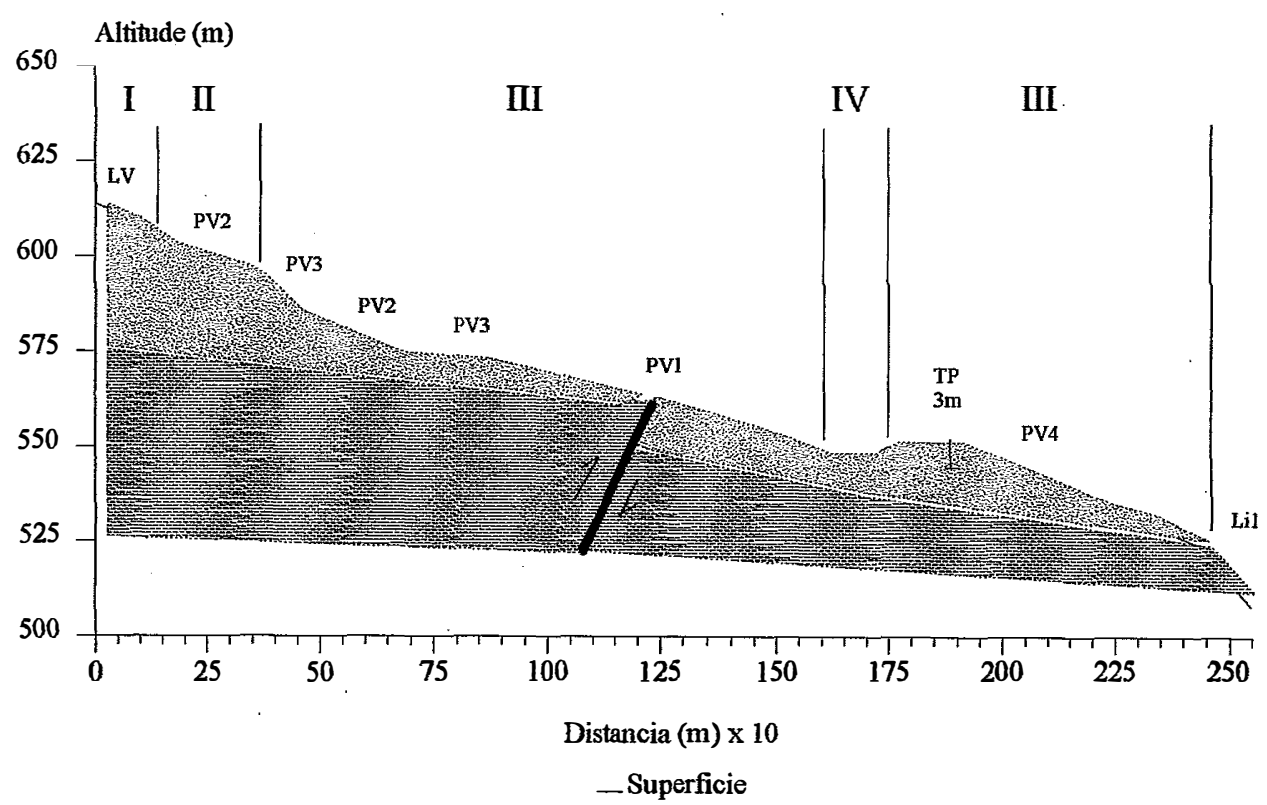

Arenito da formação Pirambóia

Siltitos da formação Corumbataí

Figura 7: Perfil topográfico mostrando a falha geológica normal localizada na vertente da transeção 2 evidenciando o abatimento da camada de arenito posicionando-a na cota $540 \mathrm{~m}$ de altitude. 
Observando-se a microbacia como um todo, nota-se que em sua cabeceira assim como na margem esquerda do ribeirão Marins, a camada de arenito vai-se tornando cada vez mais espessa. Isso sugere um mergulho das camadas no sentido N-S e inclinação no sentido Sul, o que está de acordo com o que é descrito para as rochas paleo e mesozóicas da região (PENTEADO, 1976; BJONBERG \& LANDIM, 1966; IPT, 1981).

A diferenciação quantitativa das litologias, identificadas apenas em campo, foi feita indiretamente através do estudo da distribuição estatística das frações de areia dos solos correspondentes a cada litologia (PEREZ FILHO, 1980; PRADO, 1986; TREMOCOLDI \& STEINHARDT, 1987; VIDAL-TORRADO, 1994 e COELHO et al., 1994). Segundo esta metodologia, materiais diferentes possuem uma distribuição distinta da fração areia. Para esta análise foi utilizado o programa "Phi" de VAN LIER \& VIDALTORRADO (1992). Tendo em mente a limitação metodológica da utilização de apenas 5 frações de areia, além disso determinadas por análise de rotina, analisou-se a distribuição dessas frações nos diferentes materiais de origem. Mas apesar desta restrição, foram observadas diferenças entre materiais de origem diferentes. VIDAL-TORRADO (1994) e COELHO et al. (1994) também utilizaram 5 frações de areia determinadas através de análise de rotina para análise da distribuição estatística de areias e obtiveram resultados satisfatórios. Para esse estudo foram utilizados 6 pontos da transeção 1 e cinco amostras da tradagem profunda do topo que representam solos da cobertura neo-cenozóica. Utilizou-se também cinco pontos da transeção 2 e amostras de um perfil derivado de arenito que representam solos da formação Pirambóia e finalmente 5 pontos amostrados ao acaso nos sedimentos do Corumbataí. As amostras referem-se à camada subsuperficial do solo. A distribuição estatística das frações areia da transeção 1 assemelha-se com a da tradagem profunda, o perfil de arenito assemelha-se com os pontos da transeção 2 e a distribuição dos pontos do corumbataí mostrou-se distinto das demais. Assim obteve-se três padrões distintos de distribuição, referentes a cobertura neo-cenozóica, formação Pirambóia e Corumbataí. Essas distribuições podem ser vistas na Figura 8. Observando-se a distribuição das areias da transeção 2 , nota-se que o primeiro ponto assemelha-se mais com a distribuição obsevada para a cobertura neo-cenozóica porque esta transeção inicia-se nesta cobertura. Na transeção 1, dois padrões de distribuição foram observados, isso é devido a uma provável diferença de material de origem a partir do ponto 10 , ou a partir da metade da transeção. Essa diferença também foi evidenciada pela relação areia muito fina/fina (AMF/F) analisada nessa transeção (Figura 9). 
\% Transeção 1

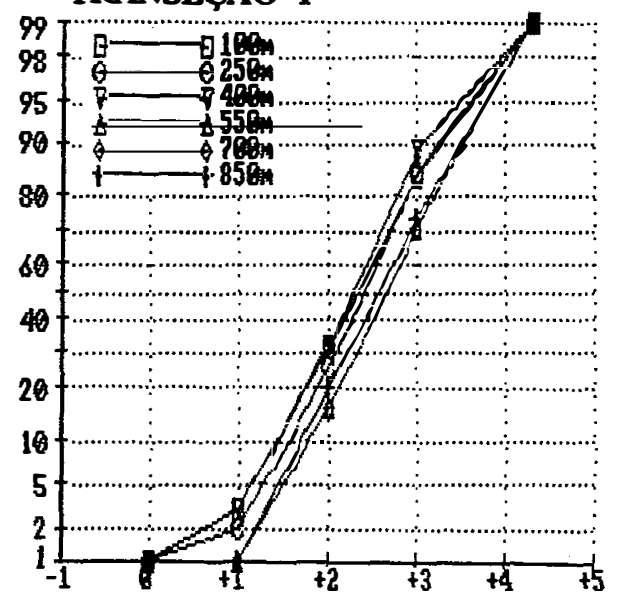

\% TRANSEÇÃO 2

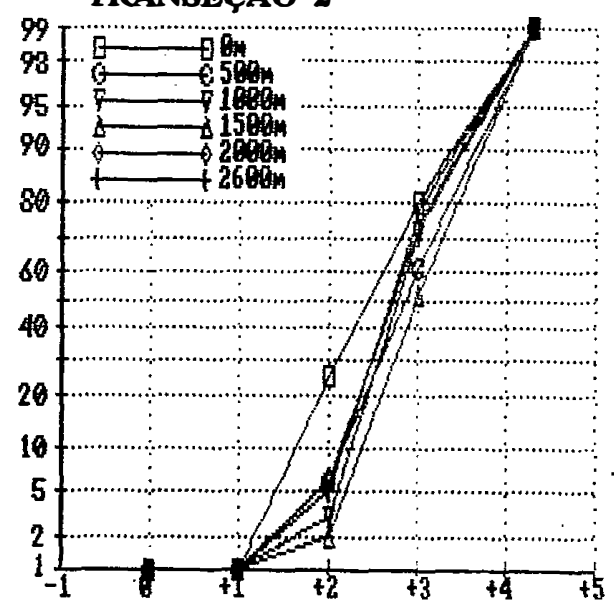

\% PONTOS CORUMBataf

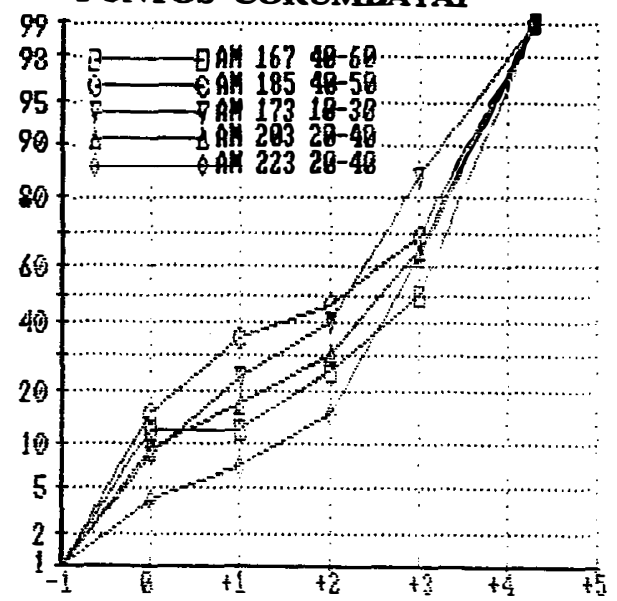

TRADAGEM PROFUNDA

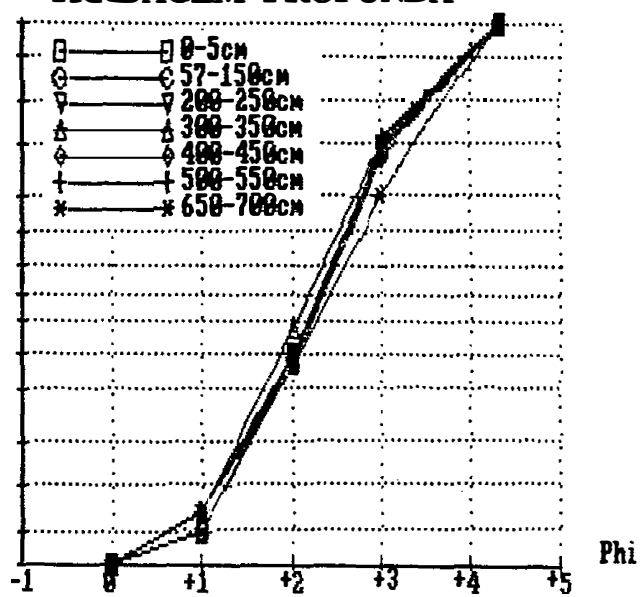

PERFIL PIRAMBÓIA

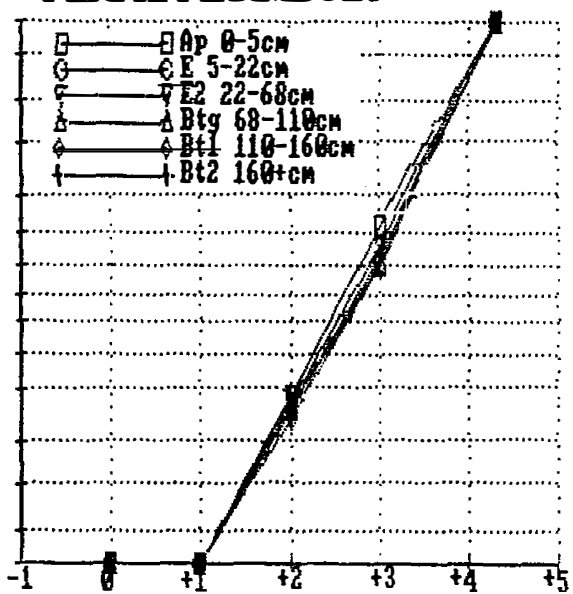

Phi

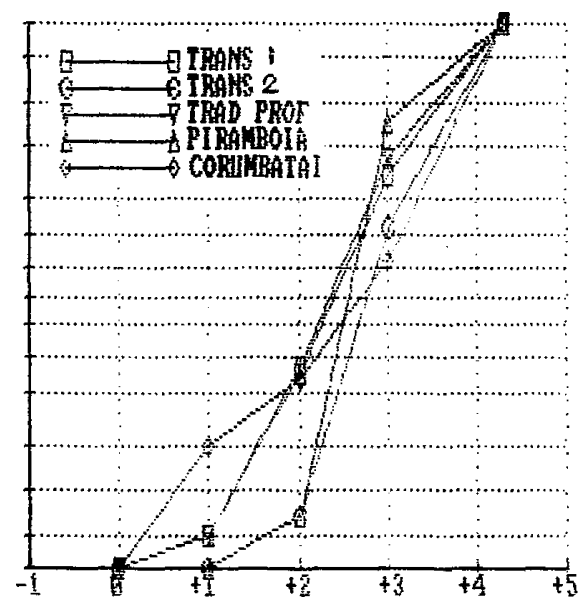

Figura 8: Distribuição estatística de 5 frações de areia referentes à cobertura neo-cenozóica, formação Pirambóia e formação Corumbataí. 


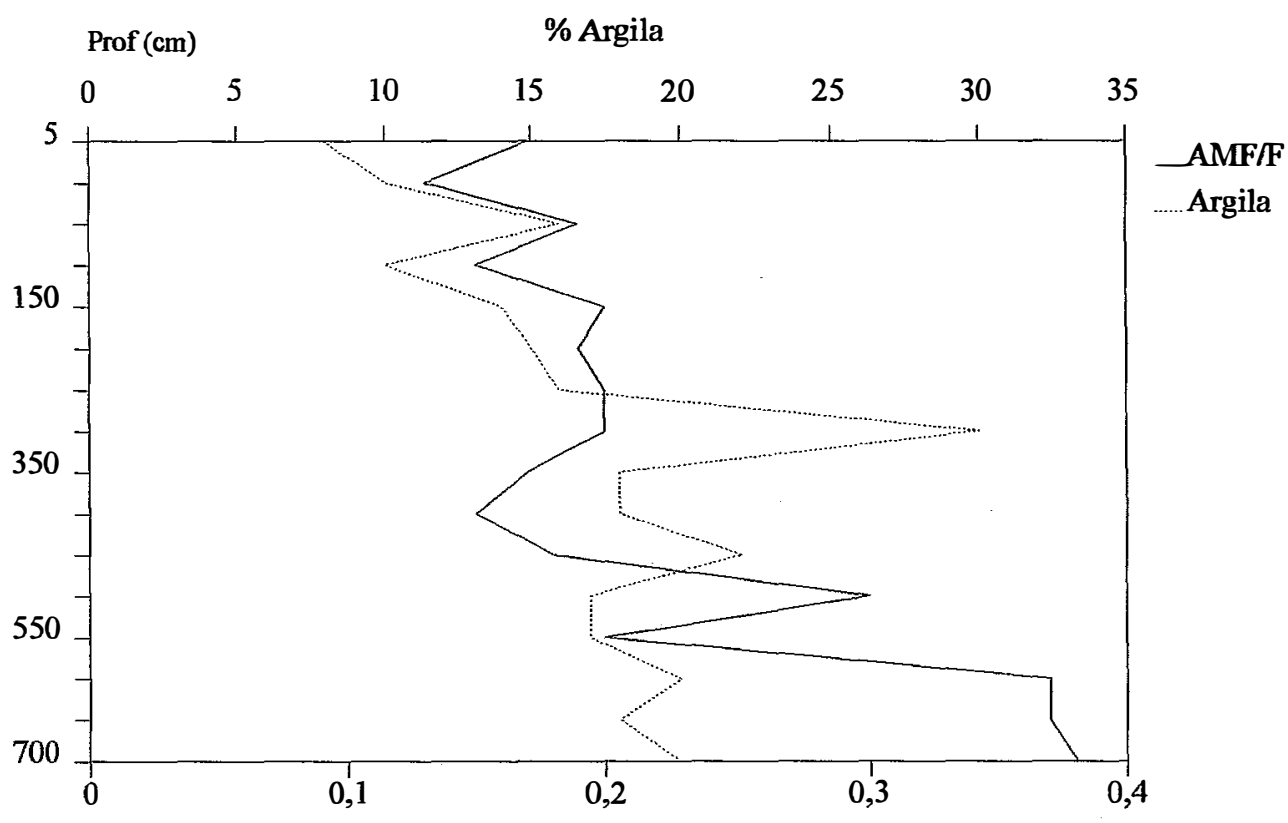

Rel. AMF/F

Figura 9: distribuição do teor de argila e da relação areia muito fina/fina (AMF/F), na tradagem profunda realizada no topo da área.

A distribuição da relação areia muito fina/fina e da argila em profundidade no topo da área, onde ocorre a superficie I, indica que existe um incremento de argila em profundidade, assim como uma variação da relação areia muito fina/fina, sugerindo que pode existir uma mudança de material em profundidade, verificada principalmente a partir de $4,5 \mathrm{~m}$ de profundidade.

\subsection{Superfícies geomórficas}

O relevo da área assim como as transeções 1 e 2, estão representados no bloco diagrama (Figura 10). 

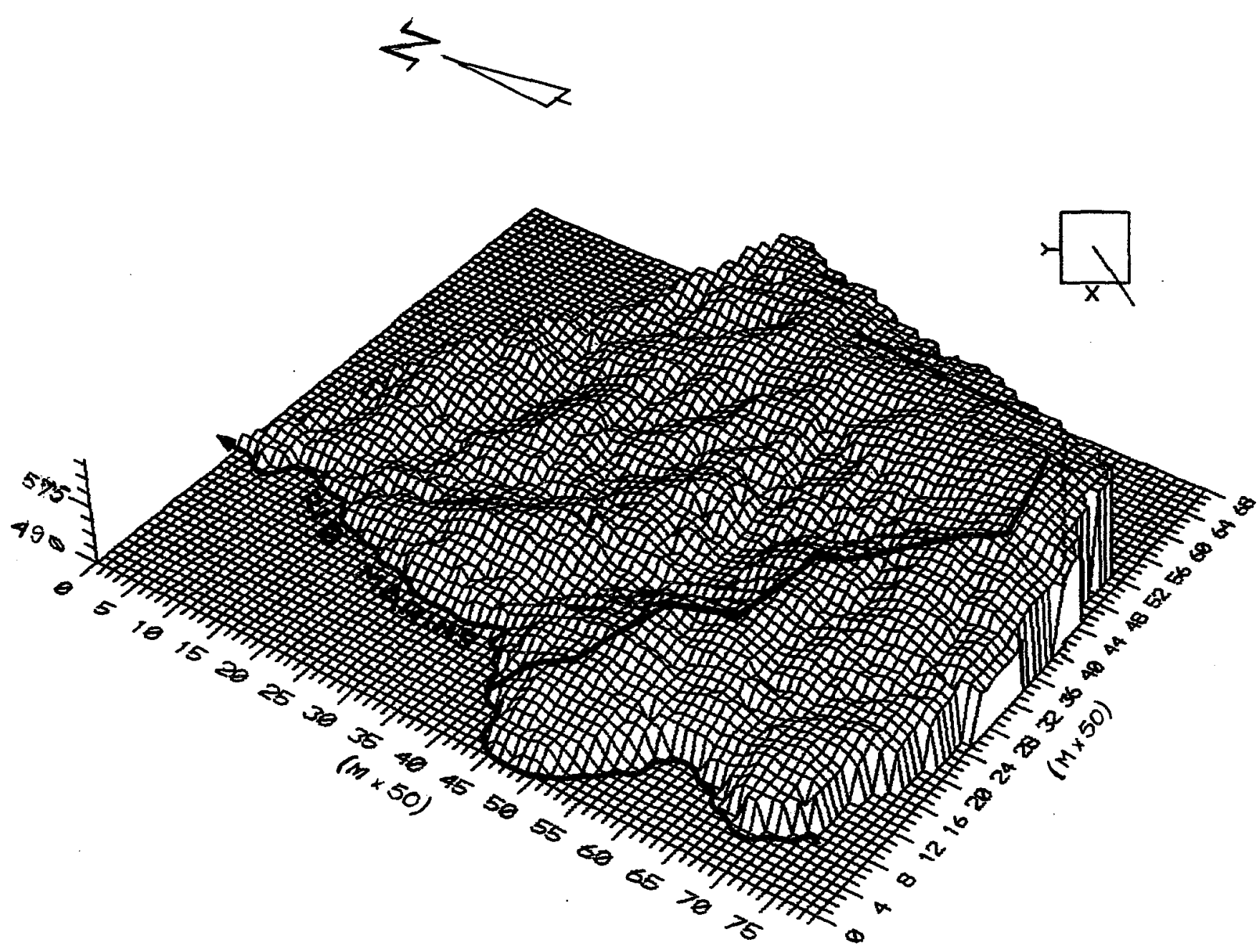

Figura 10: Bloco diagrama representando o relevo do local estudado e das áreas vizinhas. as transeções 1 e 2 também estão representadas.

Utilizando-se os critérios de DANIELS et al. (1971) para separação de superfícies geomórficas, foram identificadas 5 superfícies, que estão representadas no mapa (Figura 11) e nos cortes esquemáticos (Figura 12). 


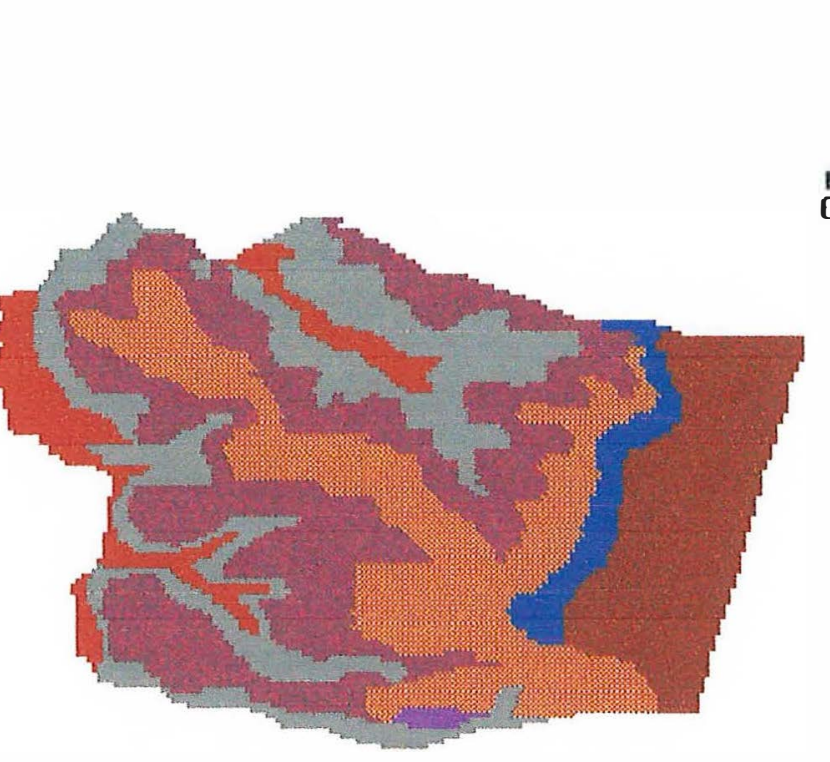

Superficie I

Superficie II

Superficie III 䇛网

Superficie IV

Superficie V

Suprficie Vd

Figura 11: Mapa de superfícies geomórficas.

A tabela 2 mostra as áreas de cada superficie geomórfica e sua porcentagem em relação à área total. A superfície IV é dominante na área, indicando que o relevo é bastante dissecado e dominado por encostas íngremes, que é característica da superficie $\mathrm{V}$ também. 
E

F

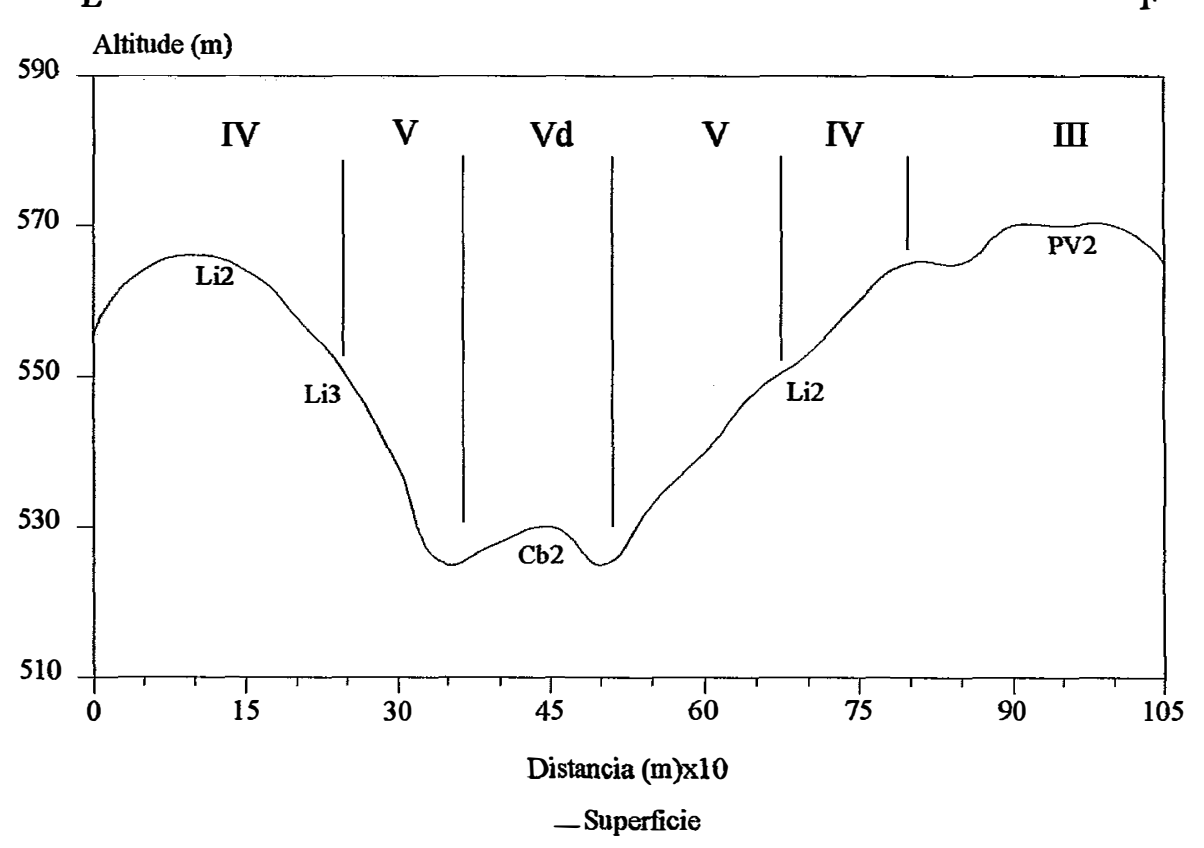

C

$\mathrm{D}$

Altitude (m)

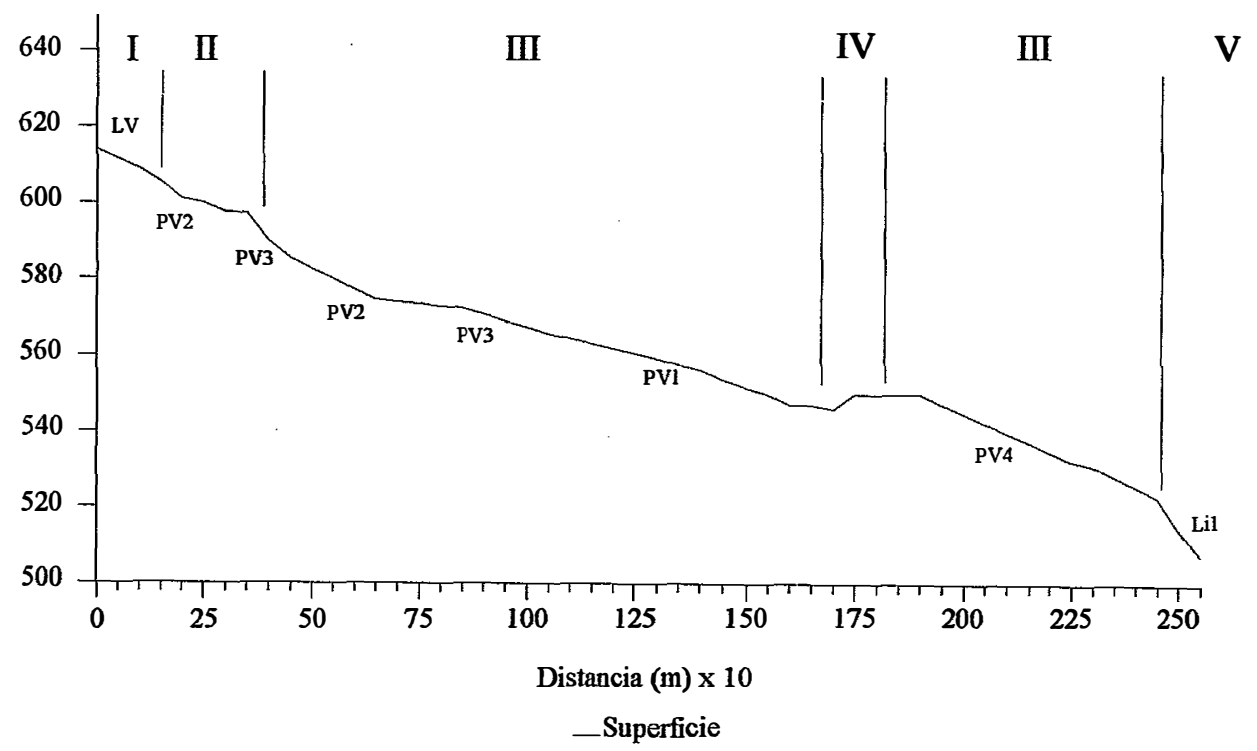

Figura 12: Cortes esquemáticos mostrando as diferentes superfícies geomórficas, onde $A B$ e CD estão indicados no mapa da figura 2. Os solos que ocorrem nestes cortes estão representados por suas respectivas legendas e estão indicadas na figura 14. 
Tabela 2: Área das superfícies geomórficas e sua porcentagem em relação à área total.

\begin{tabular}{ccc}
\hline $\begin{array}{c}\text { Superfícies } \\
\text { Geomórficas }\end{array}$ & Área (ha) & $\begin{array}{c}\text { \% da área } \\
\text { total }\end{array}$ \\
\hline IV & 141,9 & 31,1 \\
III & 99,1 & 21,7 \\
V & 94,1 & 20,6 \\
I & 68,6 & 15,0 \\
IV d & 34,9 & 7,6 \\
II & 17,1 & 3,7 \\
\hline Total & $\mathbf{4 5 5 , 7}$ & $\mathbf{1 0 0}$
\end{tabular}

A superfície I é formada por um platô compreendido no divisor de águas da microbacia e está situado aproximadamente nas cotas 615 a $620 \mathrm{~m}$. Provavelmente esta superfície se estenda em direção sul e sudeste da área fazendo parte de um grande platô regional. Seu declive não ultrapassa $5 \%$ e não existem vias de drenagem definidas. Entretanto o padrão de drenagem desse grande platô é típico de solos com boa permeabilidade, ou seja, vias de drenagens bem espassadas entre si.

Essa superficie pode ter se formado por processos erosivos ou deposicionais, mas CRISTOFOLETTI (1983) cita que estas formações superficiais na região de Piracicaba tem origem coluvial. $\mathrm{O}$ fato dessa superficie estar assentada sobre uma cobertura pedimentar espesssa $(>7,0 \mathrm{~m})$, bastante permeável, e de textura média, e aliado ao relevo plano, sugere que esta superfície é de caráter deposicional. O declive pouco acentuado, a baixa densidade de drenagem e sua situação de topo conferem a essa superficie uma grande estabilidade geomórfica e sugere ser um remanescente bastante antigo. Essa superficie assemelha-se à superficie Echaporã descrita por LEPSCH (1977) e à superficie I descritas no município de Piracicaba por LOBO (1984) e por VIDALTORRADO (1994).

Outro fato que reforça a idéia de que esta superfície é de caráter deposicional é que a cobertura neo-cenozóica subjacente a esta superficie, assenta-se sobre diferentes formações geológicas, ou seja essa cobertura é mais recente que as formações geológicas subjacentes. Se a superfície I foi depositada, então ela recobre uma outra 
suprficie mais antiga, que estava sobre a formação Pirambóia e que atualmente está soterrada pelos sedimentos cenozóicos.

Essa cobertura é uma feição que tem sido observada em outras regiões do Estado.como por exemplo, em Rio Claro (PENTEADO, 1976), em Echaporã (LEPSCH, 1977) e em Piracicaba LOBO (1984) e (VIDAL-TORRADO,1994). Provavelmente esta superfice esteja relacionada com a superfície Rio Claro, caracterizando-se como parte de um antigo pediplano da bacia do Rio Piracicaba (BIGARELA, 1965; BJORNBERG \& LANDIM, 1966; PENTEADO, 1978; OKA-FIORI \& CHRISTOFOLETTI, 1983).

A superfície II corresponde à borda da superfície I, costituindo-se quase que num ombro da encosta. Possui declividade superior a $5 \%$ e está em sua maior parte sobre o arenito da formação Pirambóia. A situação topográfica confere instabilidade geomórfica. Provavelmente resultou do entalhe provocado pelo ribeirão Marins no pediplano outrora existente sendo portanto de origem erosional.

Como esta superfície constitui uma faixa estreita abaixo da superfície I, não possui vias de drenagens bem definidas, a não ser os sulcos causados pela erosão devido ao uso da terra pelo homen. Esta superficie esta ligada com as superficies I e III.

A superficie III, de caráter erosional, está localizada predominantemente no divisor de águas dos esporões de uma vertente, constituido por um lançante longo e estreito que se orienta do topo para o ribeirão Marins, onde a declividade está em torno de 3 a 5\%. A superfície II praticamente separa esta superfície da superfície I a não ser por uma pequena faixa em que esta superfície articula-se diretamente com a superfície I.

$\mathrm{Na}$ área existem dois esporões, aproximadamente paralelos entre si e orientados no sentido do topo para o ribeirão, e que apesar de estarem situados em cotas semelhantes, aproximadamente $565 \mathrm{~m}$, não pertencem à mesma superfície geomórfica.

$\mathrm{Na}$ vertente mais a leste e limite da área, existem dois remanescentes em forma de pequenos topos quase planos que se preservaram em função da existência da camada de sílex. A superficie desta vertente está assentada sobre os sedimentos da formação Corumbataí. Na outra vertente, em que foi amostrada a transeção 2 , o topo é relativamente estreito e plano (Figura 13). Na primeira vertente a superfície é a IV e na segunda a superfície é a III. A primeira superfície, com os remanescentes, foi classificada como IV porque partiu-se da hipótese de que a superficie III, superposta a esta, já foi erodida e por não existir uma ruptura no declive que caracterize este pequeno topo como 
uma superfície distinta, no caso a III. Aparentemente o evento que erodiu toda a superfície III, na primeira vertente, não o fez completamente na segunda vertente.

Duas hipóteses foram formuladas para explicar a presença de duas superficies diferentes em cotas semelhantes. 1) A superficie III estaria sobre material de origem coluvial, depositado posteriormente à formação da superfície IV, concordando com o modelo de BIGARELLA, (1965) de evolução da paisagem. 2) Existe um falhamento geológico nesta vertente que provocou o rebaixamento deste bloco fazendo com que esta superfície, originalmente em altitude superior, ocorresse nesta cota.

Para testar a primeira hipótese realizou-se uma tradagem profunda para verificação do material de origem. Aos $3 \mathrm{~m}$ de profundidade encontrou-se saprolito de arenito, descartando a hipótese de que esta superfície estaria repousando sobre sedimentos de origem coluvial.

Partiu-se então em busca de evidências que confirmassem a hipótese da existência de um falhamento geológico. As feições das grotas próximas foram analisadas e constatou-se vestígio de uma provável falha, onde uma via de drenagem havia se instalado. Outra evidência que corrobora a presença da formação Pirambóia neste local é que os solos ai presentes são predominantemente arenosos e relativamente profundos. Ao contrário, na outra vertente, os solos são argilosos e pouco profundos uma vez que derivam de sedimentos finos e impermeáveis da formação Corumbataí. Esta é, portanto, uma forte relação existente entre o material de origem e os solos encontrados. Tal fato mostra a importância do conhecimento da litologia local para se compreender a gênese e distribuição dos solos como preconizam ARNOLD (1983); BUOL et al., (1980) e BIRKELAND, (1984) .

Nesta superfície o movimento de massa é nítido, evidenciado através da presença de "terracets". Existem quebras de declive devido ao controle litológico provocado pela camada de sílex. Durante os processos erosivos de esculturação da paisagem, mais especificamente no recuo das encostas, a resistência desta camada provocou uma quebra no declive devido a erosão diferenciada. A encosta então tomou a forma de degraus com patamares, sugerindo mais de uma superfície na mesma encosta. Como essa feição não foi devida a um evento geomorfológico, mas sim a um controle litológico, não se justifica a separação de mais de uma superfície, segundo critérios de DANIELS et al. (1971). Esta feição de degraus na encosta também foi verificada por LEPSCH (1977) em escarpas areníticas e por VIDAL-TORRADO (1994) em patamares 
estruturais controlados pela litologia da formação Tatuí. Tais degraus situam-se sobre camadas de arenitos mais resistentes, sendo portanto feições controladas pelo substrato rochoso e não por eventos geomorfológicos.

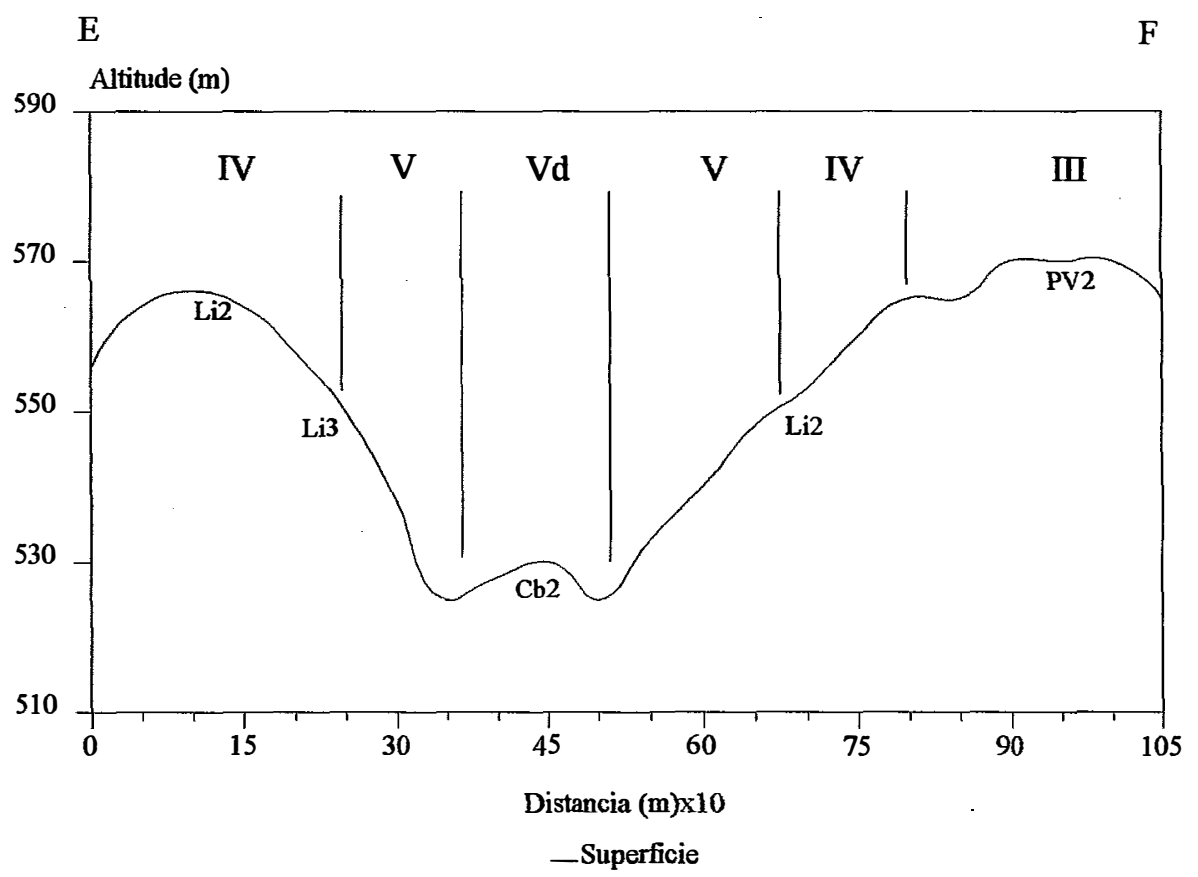

Figura 13: Corte esquemático EF mostrando duas vertentes cujos topos estão em cotas iguais porém com superficies geomórficas diferentes. Os solos que ocorrem neste corte estão representados por suas respectivas legendas e estão indicadas na figura 14.

A superfície $\mathrm{V}$ corresponde às escarpas e vales, sendo que estes se direcionam para o ribeirão Marins. Nesta superfície encontram-se os declives mais acentuados, comumente superiores a $10 \%$. A litologia pasa a ser contituída pelos sedimentos argilosos (siltitos $\mathrm{e}$ folhellhos). Nesta superfície os vales são predominantemente em forma de "V". Nas encostas destes vales também é comum observar sequência de pequenos degraus, onde por vezes afloram os siltitos e folhelhos. Estes degraus são evidências do movimento de massa como foi verificado na superficie IV. 
A superfície $V$, grada diretamente para a drenagem central englobando as vias de drenagens mais recentes. Foram separadas sua porção erosional e deposicional. No entanto, o fundo dos vales apresentam-se preenchidos por sedimentos de erosão, e principalmente nas cabeceiras, esse acúmulo é maior. Nestas áreas a superfície V deixa de gradar suavemente para estes novos sedimentos, fícando uma parte de sua porção deposicional soterrada pelos mesmos.

Esses depósitos configuram nova superfície, ainda mais porque o canal de drenagem passa a cortar, agora, esses sedimentos neogênicos que preenchem o fundo dos vales. Estes novos depósitos foram formados devido a interferência do homem na natureza, e são denominados depósitos tecnogênicos (IPT, 1981). As superfícies IV e V possuem muitas vias de drenagem que são sulcos de erosão. Estes sulcos conectam-se diretamente com o curso dágua da superfície $\mathbf{V}$.

Cronologicamente e de acordo com os critérios de DANIELS et al. (1972) a superficie I é a mais antiga de todas porque está na cota mais elevada e não grada para nenhuma outra acima dela. A superfície II é mais recente que a I porque a corta. A superfície III é mais recente que a II e a I porque as cortam e é mais velha que a IV porque é seccionada por esta. A superfície $\mathrm{V}$ é a mais nova porque grada diretamente para o córrego. A superfície $\mathrm{V}$ erosional tem a mesma idade da superfície deposicional para a qual grada. Como existe uma bancada de silex resistente que controla o relevo local, as vertentes não evoluem uniformemente possuindo invariavelmente quebras de relevo devido a esse controle litológico.

Dessa maneira algumas encostas não seguem os padrões ou teorias de evolução das vertentes de Davis, Penk e King ou Hack, mas parece que o modelo de King em que o topo é preservado acontece, mesmo com o recuo irregular das encostas. Tomando-se a área como um todo, o modelo de BIGARELLA (1965), de alternâncias climáticas, parece ser mais adequado para explicar a paisagem, e as superficies geomórficas.

\subsection{Solos}

Foi realizado um levantamento de solos detalhado da área onde grande parte dos limites entre as unidades de solos foram verificadas no campo, uma vez que este 
levantamento foi realizado por caminhamentos. O trabalho de campo foi bastante valorizado sendo realizado de forma a se obter o máximo de informação possível.

No levantamento pedológico foram identificadas 10 unidades de mapeamento as quais foram reunidas no mapa a seguir (Figura 14):

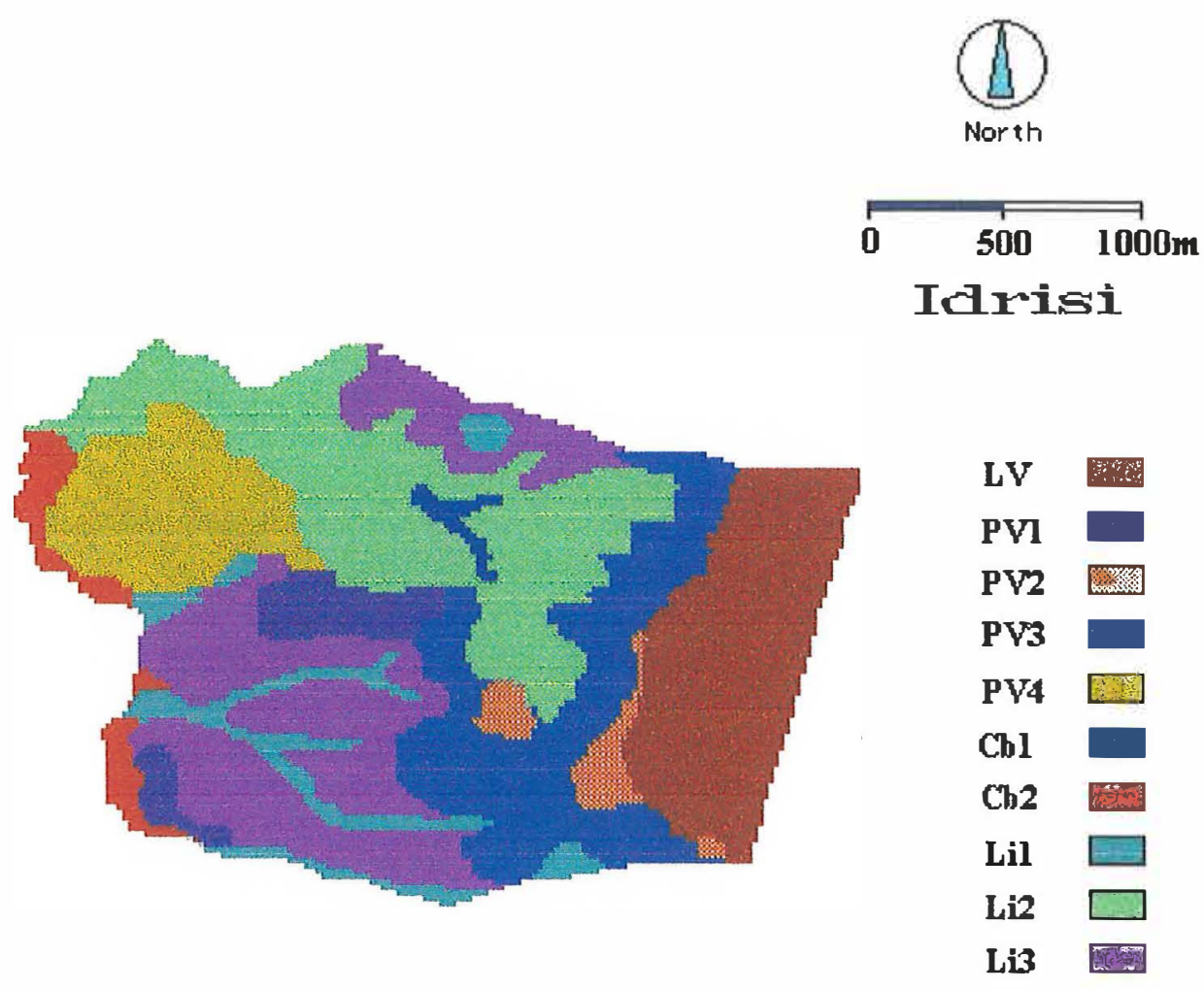

Figura 14: Mapa de solos 


\subsubsection{Legenda do Mapa de Solos}

LV Latossolo Vermelho-Amarelo, álico ou distrófico, A moderado, textura média

PV1 Podzólico Vermelho-Amarelo, álico ou distrófico, Ta ou Tb, A moderado, textura média/argilosa

PV2 Podzólico Vermelho-Amarelo, álico ou distrófico, Ta ou Tb, A moderado (A+E espesso), abrupto, textura arenosa/ média

PV3 Podzólico Vermelho-Amarelo, álico ou distrófico, Ta ou Tb, A moderado, abrupto, textura arenosa/ média

PV4 Podzólico Vermelho-Amarelo, distrófico, Tb, A moderado, abrupto, textura arenosa/ média

Cb1 Cambissolo eutrófico, distrófico ou álico, textura indiscriminada, substrato sedimentos aluvionais

Cb2 Cambissolo eutrófico, distrófico ou álico, textura indiscriminada, substrato sedimentos coluviais

Li1 Litólico álico ou distrófico, $\mathrm{Ta}$ ou $\mathrm{Tb}, \mathrm{A}$ moderado, textura argilosa substrato siltitos da formação Corumbataí

Li2 Litólico indiscriminado, substrato siltitos e folhelhos com sílex da formação Corumbataí

Li3 Complexo de Li1 e L12 e Cambissolos indiscriminados e Podzólicos VermelhoAmarelos indiscriminados fase pouco profundos todos substratos siltitos e folhelhos da formação Corumbataí 
Tabela 3: Área de ocorrência das unidades de mapeamento e respectiva porcentagem em relação à área total.

\begin{tabular}{ccc}
\hline $\begin{array}{c}\text { Unidade de } \\
\text { Mapeamento }\end{array}$ & Área (ha) & $\begin{array}{c}\text { \% da área } \\
\text { total }\end{array}$ \\
\hline Li1 & 99,6 & 21,8 \\
Li3 & 95,0 & 20,8 \\
LV & 72,9 & 15,9 \\
PV3 & 70,3 & 15,4 \\
PV4 & 44,6 & 9,7 \\
Li2 & 26,2 & 5,7 \\
PV1 & 18,4 & 4,0 \\
Cb1 & 14,4 & 3,1 \\
PV2 & 10,6 & 2,3 \\
Cb2 & 3,7 & 0,8 \\
\hline Total & $\mathbf{4 5 5 , 7}$ & $\mathbf{1 0 0 , 0}$
\end{tabular}

Pela Tabela 3 nota-se que a área é dominada por solos rasos representados pelas unidades $\mathrm{Li} 1, \mathrm{Li} 2, \mathrm{Li} 3, \mathrm{Cb} 1$ e $\mathrm{Cb} 2$ o que está de acordo com a dominância de locais íngremes na área, referente as encostas das superficies IV e V, onde dominam siltitos da formação Corumbataí.

\subsubsection{Latossolo Vermelho-Amarelo}

Esta classe compreende a unidade de mapeamento LV, situada no topo da área. $\mathrm{O}$ material de origem é a cobertura neo-cenozóica, caracterizada por material retrabalhado de textura média. Corresponde a unidade Laranja Azeda de OLIVEIRA \& PRADO (1989).

O teor de argila varia em torno de 20 a $30 \%$ considerando a camada 60-80 cm, tida como representativa do horizonte $B$, mas mesmo na tradagem profunda $o$ teor de argila não ultrapassou $23 \%$ até os $7,0 \mathrm{~m}$ (Figura 9). Na camada superficial de 0-20 
cm a quantidade de areia é maior, sendo que nela o teor de argila não ultrapassou $20 \% \mathrm{em}$ nenhum ponto. A origem dessa areia é provavelmente de arenitos da formação Pirambóia que ocorre a altitudes superiores a noroeste da área estudada. A cor desse solo varia gradualmente em profundidade do matiz 7,5 YR para 2,5 YR, ou seja, quanto maior a profundidade mais vermelho torna-se o solo.

Morfologicamente esse solo apresenta pouca variação vertical em textura, estrutura, consistência e outros atributos físicos e químicos, como é característico dessa classe. Essa uniformidade foi verificada até 7,0 m de profundidade. A estrutura pode ser descrita como tendo aspecto maciço e poroso em todo o perfil. Devido a grande quantidade de areia (70\%) é possível ver a olho nu, quando examinado mais cuidadosamente, grãos de quartzo individualizados na massa do solo. No perfil foram observados restos de carvão até a profundidade de $50 \mathrm{~cm}$. Quanto às características químicas, esse solo é pobre em bases, com saturação por alumínio (m\%) em torno de $80 \%$. A CTC a pH 7 tem valores abaixo de $6 \mathrm{meq} / 100 \mathrm{~g}$ TFSA confirmando sua classificação na classe Latossolo. Essa classe ocupa 72,9 ha, perfazendo 15,9 \% da área total estudada.

\subsubsection{Podzólico Vermelho-Amarelo}

Essa classe inclui as unidades de mapeamento PV1, PV2, PV3 e PV4 todos originados parcial ou totalmente dos sedimentos arenosos da formação Pirambóia. Com excessão da unidade PV1, que possui textura média/argilosa, as demais possuem textura aresosa/média. Correspondem à unidade Serrinha de OLIVEIRA \& PRADO (1989).

A unidade PV1 tem pouca representatividade em termos de área, apenas $4,0 \%$ da área total ou 18,4 ha. Apesar de sua textura ser méda/argilosa o teor de argila na camada de $60-80 \mathrm{~cm}$ não ultrapassa $45 \%$ e na camada superficial raramente atinge $25 \%$ de argila. Essa unidade situa-se na porção mediana da encosta em que foi realizada a transeção 2 , em situação de divisor de águas com relevo quase plano, numa área ligeiramente deprimida, o que pode ser um indício de que neste local houve contribuição de argila dos folhelhos da formação Corumbataí situados imediatamente abaixo. Pode ser ainda devido ao próprio arenito ligeiramente mais argiloso, o que é possível na formação Pirambóia. É relativamente pobre em bases, sendo que em alguns pontos essa unidade apresenta-se álico e em outro distrófico 
A unidade PV2 tem como particularidade a presença de horizonte $\mathrm{A}+\mathrm{E}$ muito espesso e arenoso. Essa camada é denominada por alguns pedólogos como horizonte A espesso. Essa denominação encontra correspondente na classificação americana (E.U.A., 1990) como "arenic" se a espessura de A+E estiver entre 50 a $100 \mathrm{~cm}$ a partir da superfície do solo ou "grossarenic" se essa espessura for superior a 100cm. BADELUCI et al. (1990) propôs o termo arênico para designar solos com esse horizonte superficial espesso e arenoso. A transição entre o horizonte $\mathrm{A}+\mathrm{E}$ e o $\mathrm{Bt}$ é abrupta. No topo do $\mathrm{Bt}$ foram encontrados sinais de gleização evidenciando encharcamento temporário. A estrutura no horizonte $\mathrm{A}+\mathrm{E}$ é de grãos simples e no horizonte $\mathrm{Bt}$ é de blocos subangulares de grau moderado, a cerosidade, se existente, é fraca e pouco expressiva. Esse solo ocupa posição de encosta com declividade superior a $10 \%$ e margeia o LV. Representa $10,6 \%$ da área total. Essa unidade parece ser de ocorrência relativamente comum na quadrícula de Piracicaba, e também foi encontrada na área por OLIVEIRA \& PRADO (1989).

As unidades PV3 e PV4 diferem apenas quanto às características químicas, sendo a unidade PV3 álicos ou distróficos e a unidade PV4 apenas distrófico. Morfologicamente são semelhantes, possuem a mesma textura (arenosa/média), tem transição abrupta entre horizontes, possuem estrutura em blocos subangulares de grau moderado a fraco e espessura do solum em torno de 2,0 m. Do ponto de vista de fertillidade são pobres em bases, haja vista o caráter álico e distrófico dos mesmos. Ocorrem na mesma encosta onde é encontrada a unidade PV1, em situação de divisor de águas com declive pouco acentuado. A unidade PV3 ocorre em 15,4\% da área total enquanto a unidade PV4 representa 9,7\%.

A diferença textural entre os horizontes desses podzólicos abruptos parece não ser devida à diferença de texturas do material de origem como descritos por JIMENEZ RUEDA \& DEMATTE (1988) em arenitos da formação Marília, uma vez que verificou-se que os arenitos encontrados em afloramentos não possuem esta característica. Em um local próximo à área foram encontrados em um barranco perfís de podzólico vermelho-amarelo com lamelas no horizonte $\mathrm{E}$. A presença dessas lamelas, e o material de origem uniforme em termos texturais, sugere que o horizonte superficial arenoso desses solos deve ter sido formado principalmente por destruição e remoção ou iluviação de argila do perfil das camadas superficiais como sugerem QUEIROZ NETO, (1975); ESWARAM \& SYS, (1979), SCHWERTMANN et al., (1983), CASTRO (1989) e VIDAL-TORRADO (1994). 
Não foram encontrados também solos podzólicos derivados de siltitos da Corumbataí a não ser alguns pouco profundos ou rasos. PRADO (1986) estudou os podzólicos desenvolvidos de folhelhos do Corumbataí em comparação aos podzólicos derivados de arenito Pirambóia para verificar se a camada superficial arenosa do podzólico dos folhelhos do Corumbataí era de origem coluvial, concluindo que existe pequena contribuição do arenito Pirambóia no solo desenvolvido das rochas da formação Corumbataí, sendo que essa contribuição é verificada principalmente na fração areia.

\subsubsection{Cambissolos}

Os cambissolos da área são representados pelas unidades $\mathrm{Cb} 1 \mathrm{e} \mathrm{Cb} 2 \mathrm{e}$ são originados por sedimentos aluviais e coluviais respectivamente. $\mathrm{O} \mathrm{Cbl}$ ocorre na margem do ribeirão Marins e é formado por seus depósitos aluviais, mas como sua planície fluvial é pequena, o ribeirão contribui com poucos sedimentos. $\mathrm{O} \mathrm{Cb} 2$ é encontrado no fundo dos vales, na porção deposicional das encostas, onde se concentram os sedimentos alúvio-coluviais. Devido ao caráter heterogêneo desses depósitos, a morfologia dessas unidades também é bastante variada assim como suas características físicas e químicas. Isso dificulta a separação mais detalhada desses cambissolos. Entretanto a unidade $\mathrm{Cb} 2$ é predominantemente de textura arenosa, porque os sedimentos ai encontrados são produtos da erosão dos solos arenosos das cotas acima. Essas unidades somam juntas 3,9\% da área total, sendo que o $\mathrm{Cb} 1$ tem $3,1 \%$ e o $\mathrm{Cb} 2$ tem $0,8 \%$ da área.

\subsubsection{Litólicos}

Os solos litólicos são representados pelas unidades Li1, Li2 e Li3, todos originados dos siltitos e folhelhos da formação Corumbataí ocupando os locais de maior declividade da área. É a classe de maior ocorrência, somando juntas $48,3 \%$ da área total. Separadamente representam $21,8 \%, 5,7 \%$ e 20,8 \% da área total respectivamente.

De maneira geral todas essas unidades possuem textura argilosa como consequência do material originário que é o siltito argiloso. A posição que ocupam na paisagem, geomorfológicamente instável, faz com que a erosão não permita o desenvolvimento maior desses solos, porque eles são constantemente rejuvenescidos pela retirada de material superficial pela erosão. Outra característica importante é que essas 
rochas dispostas em folhelhos são muito coesas e impermeáveis dificultando sobremaneira o intemperismo. Uma das características desses litólicos é a grande variabilidade dos atributos físicos e químicos e principalmente morfológicos. $\mathrm{O}$ teor de argila está em torno de 50 a $60 \%$, a saturação por bases (V\%) e por alumínio (m\%) varia muito de ponto para ponto. Em alguns perfis, a morfologia deixou dúvidas em relação a presença de horizontes $\mathrm{Bt}$ de pequena espessura ou de horizontes $\mathrm{Bi}$.

Tais questões são releventes porque a presença de um horizonte $\mathrm{Bt}$ com um mínimo de $18 \mathrm{~cm}$ de espessura seria suficiente para que o solo seja classificado como podzólico fase pouco profunda ou rasa e não como litólico ou cambissolo. Assim, as unidades Li1 e Li2 podem apresentar podzólicos fase pouco profundo ou raso e/ou cambissolos associados, mas como se admite até $20 \%$ de inclusões nas unidades de mapeamento estas unidades foram descritas como simples. Já a unidade Li3 é um complexo que inclui a unidade Lil, podzólicos fase pouco profundos e cambissolos, sendo que estes dois últimos foram apenas indicados como existentes nesta unidade.

A presença da camada contínua de sílex, ou de seus fragmentos difícultaram algumas prospecções, e como esta camada está presente em toda a área, e de forma quase contínua, a unidade Li2 foi constituída para designar os litólicos que contém esta camada e fragmentos.

\subsection{Transeções}

As ranseções permitem observar a variação lateral dos atributos químicos e físicos dos solos ao longo de uma vertente, segundo o conceito de catena (HALL, 1983). Para isso duas ranseções foram escolhidas como representativas da área em questão. 


\subsubsection{Transeção 1}

A transeção 1 está localizada no topo da área, sobre a cobertura neo-cenozóica. A amplitude topográfica entre o primeiro ponto e o último está em torno de $20 \mathrm{~m}$ e possui 20 pontos amostrados a cada $50 \mathrm{~m}$.

Convencionou-se, como representativa do horizonte $\mathrm{A}$, a camada a amostrada de 0-20 cm, e como camada b, a de $60-80 \mathrm{~cm}$, representativa do horizonte $\mathrm{B}$, quando existente.

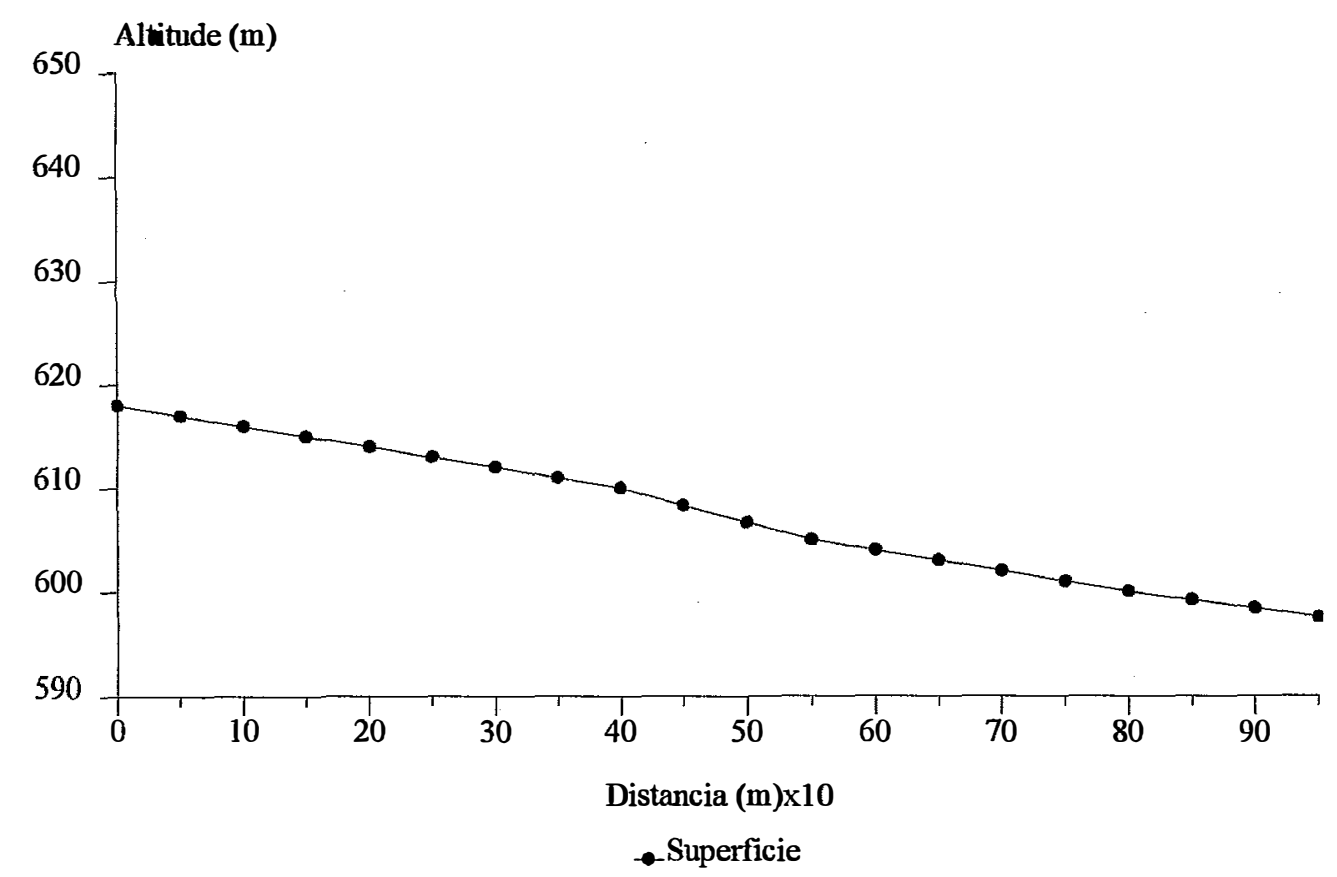

Figura 15: Perfil topográfico da transeção 1. 

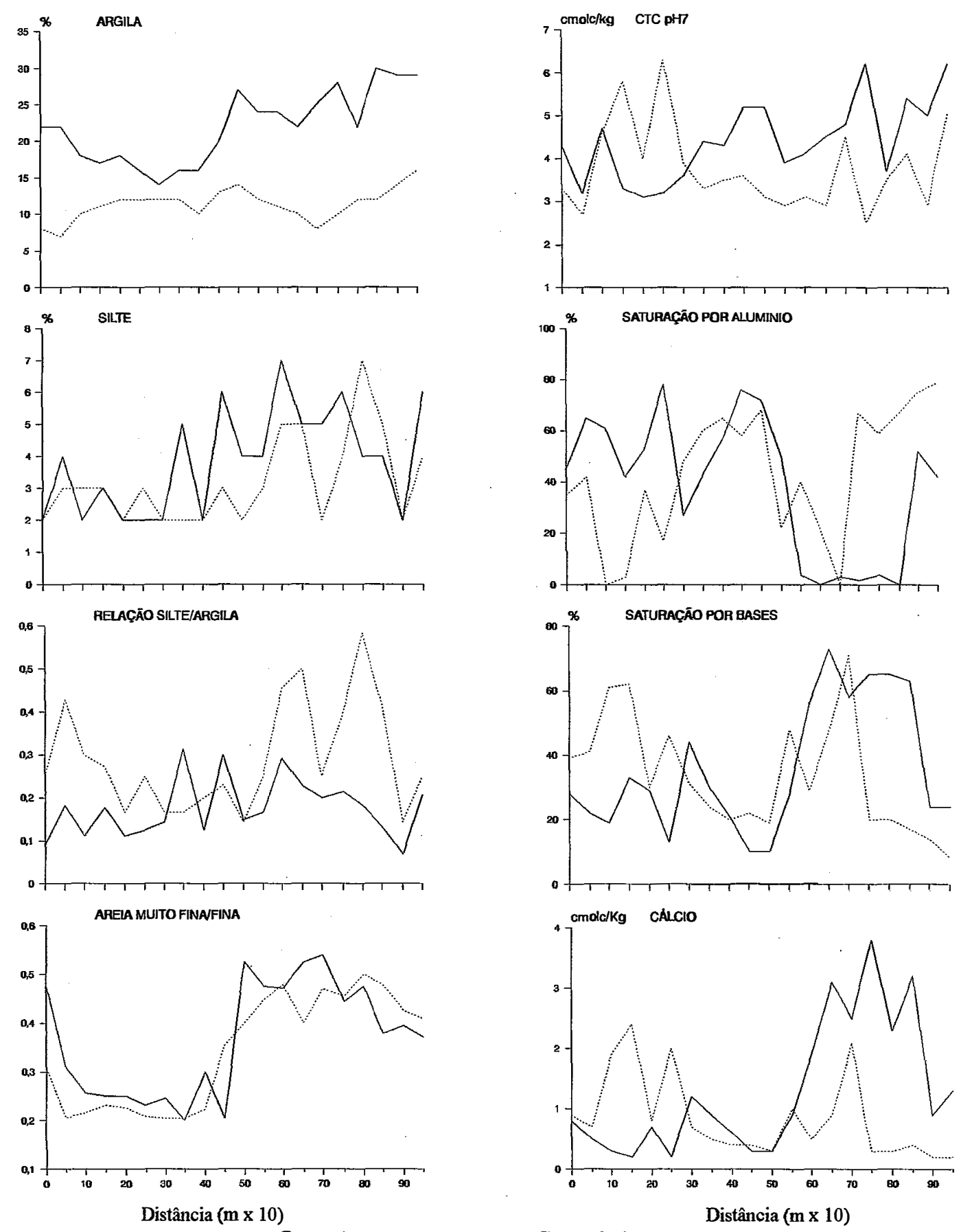

Camada a

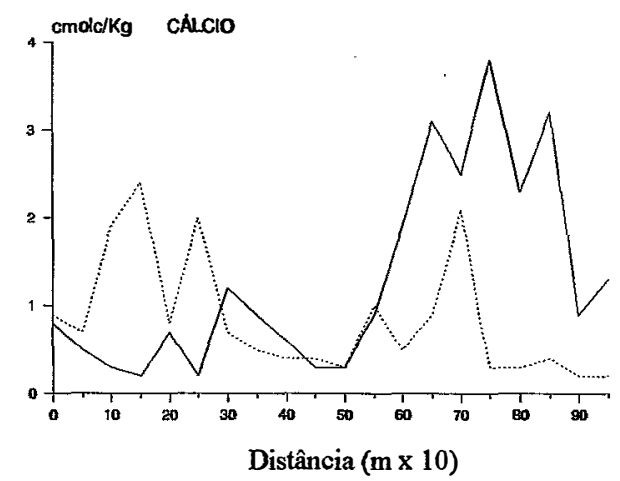

Camada $b$

Figura 16: Gráficos de alguns atributos químicos e fisicos da transeção 1 , em duas camadas. 


\subsubsection{Atributos químicos}

De acordo com a figura 16 os valores médios de saturação por bases (V\%) da camada a tende a diminuir no sentido do ponto mais alto para o mais baixo, a não ser entre os pontos 11 e 15 que mostraram valores elevados, sendo que apenas os pontos 3 , 4 e 15 são eutróficos. Nesta camada a interferência por adubações e correções do solo é muito grande. Na camada $\mathrm{b}$, os valores de V\% apresentam um aumento considerável a partir do ponto 11, sendo que entre os pontos 13 e 18 são eutróficos com V\% em torno de 60 a 70\%. Existe portanto uma região eutrófica nessa transeção, devido principalmente aos elevados teores de $\mathrm{Ca}^{+2}$ na camada $\mathrm{b}$, que são devidos a níveis carbonáticos (calcíferos) da formação Corumbataí.

A saturação por alumínio (m\%) mostrou comportamento inverso em relação ao V\%. A camada a teve aumento deste atributo ao longo da transeção enquanto na camada $b$ esses valores foram diminuindo nessa direção.

Os valores de CTC $\mathrm{pH} 7,0$ tendem a uma diminuição ao longo da transeção na camada a, estando em torno de 3 a 6 meq/100g TFSA. Na camada b, estes valores sugerem um aumento da CTC $\mathrm{pH} \mathrm{7,0} \mathrm{no} \mathrm{sentido} \mathrm{do} \mathrm{topo} \mathrm{para} \mathrm{o} \mathrm{ponto} \mathrm{mais} \mathrm{baixo,}$ esse comportamento também é verificado para os teores de argila nesta camada. Em ambas camadas os valores não excederam 6 meq/100g TFSA.

\subsubsection{Atributos físicos}

$\mathrm{Na}$ camada a, apesar de os teores de argila não apresentarem grande variação na transeção, verifica-se uma tendência de aumento na transeção, sendo que os teores variam entre 7 a $15 \%$. Na camada $b$, os teores de argila estão em torno de 15 a 30\% e parece haver um incremento no sentido do declive. Em toda a transeção, os teores de argila da camada $b$ são sempre maiores que os da camada $a$.

Os teores de silte seguem a mesma tendência do teor de argila, entretanto a variação entre pontos é maior em ambas camadas. Os teores da camada a são sempre maiores que na camada $b$.

A relação silte/argila da camada a, apresenta grande variação entre pontos, principalmente a partir do ponto 11 . Na camada $b$ esta relação parece ter uma 
tendência de aumento, mas a partir do ponto 16 a relação tende a diminuir, talvez devido ao aumento no teor de argila.

A relação areia muito fina/fina (AMF/AF) tanto na camada a como na b indicam uma mudança a partir do ponto 10 , provocada pelo aumento da quantidade de areia muito fina a partir deste ponto. Neste ponto a litologia abaixo da cobertura cenozóica muda de aenito para siltito.

A cor do solo vai se tornando cada vez mais vermelha, partindo da matiz 5 YR na parte mais alta até 2,5YR nas parte mais baixa, isso deve-se a interferência do material subjacente que passa a ser o siltito, que dessa forma é a fonte de ferro para essa coloração avermelhada.

A maior parte dos atributos químicos e físicos da camada $b$ tendem a um acréscimo de valores de soma de bases, $\mathrm{pH}$, de $\mathrm{Ca}^{+2}$ e de argila e decréscimo de saturação por $\mathrm{Al}^{+3}$ e $\mathrm{MO} \%$ no sentido do declive. A relação $\mathrm{AMF} / \mathrm{F}$ sugere uma mudança de material de origem a partir da metade da transeção.

A diferença mostrada na relação $\mathrm{AMF} / \mathrm{F}$ a partir da metade desta transeção parece ser estranha em se tratando de uma cobertura neo-cenozóica bastante antiga e intemperizada. Seria de esperar que o material fosse bastante homogêneo. Mas observando a estratigrafia local pode-se supor que na segunda metade dessa transeção essa cobertura repousa sobre sedimentos argilosos do Corumbataí e a primeira sobre o arenito Pirambóia, ou seja, deve existir algum tipo de interferência dos sedimentos do Corumbataí sobre a cobertura, como foi verificada num barranco de olaria localizada cerca de $3 \mathrm{Km}$ e que está $20 \mathrm{~m}$ abaixo do ponto mais alto da área estudada. Essa interferência é devida principalmente ao remonte biológico causada pela mesofauna do solo. Neste barranco a cobertura neo-cenozóica possui textura argilosa e está sobre folhelhos argilosos da formação Corumbataí separada desta por uma linha de pedras. Provavelmente o fato de a cobertura neo-cenozóica estar sobre rochas argilosas fez com que sua textura se tornasse mais fina também. Isso explicaria a diferença detectada pela relação AMF/F que sugere mudança de material de origem na metade da transeção 1 .

Neste contexto o falso conceito estratigráfico de que as camadas geológicas são isócronas e uniformes como camadas de bolo ou "layer cake" (GAMA FIlHO, 1989) não pode ser adotado pois não explicaria tal situação, demonstrando que o bom conhecimento de conceitos estratigráficos é muito importante em estudos de relações solo-paisagem . 


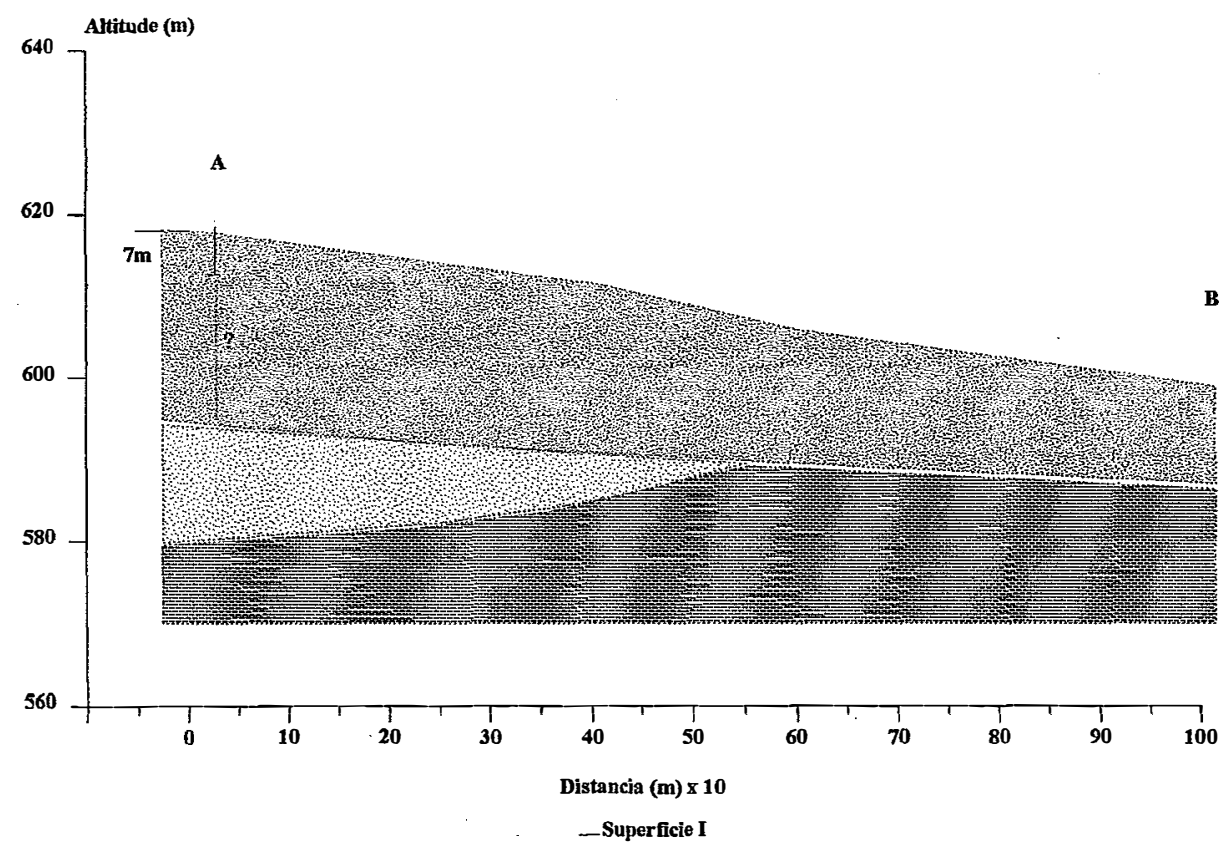

Cobertura neocenozóica

Arenitos da formação Pirambóia

Siltitos da formação Corumbataí

Figura 17: Esquema ilustrando a disposição hipotética da estratigrafia abaixo da transeção 1. De acordo com este esquema, a partir da metade desta transeção, o material abaixo da cobertura cenozóica passa a ser relativo à formação Corumbataí. Isso explicaria o aumento do teor de cálcio, argila, de silte e da relação AMF/F (Figura 18) e da distribuição das frações areia (Figura 8). 


\subsubsection{Transeção 2}

A transeção 2 situa-se no divisor de águas de uma vertente e estendese desde o topo até o ribeirão Marins Figura 18. Possui 52 pontos, amostrados a intervalos regulares de $50 \mathrm{~m}$.

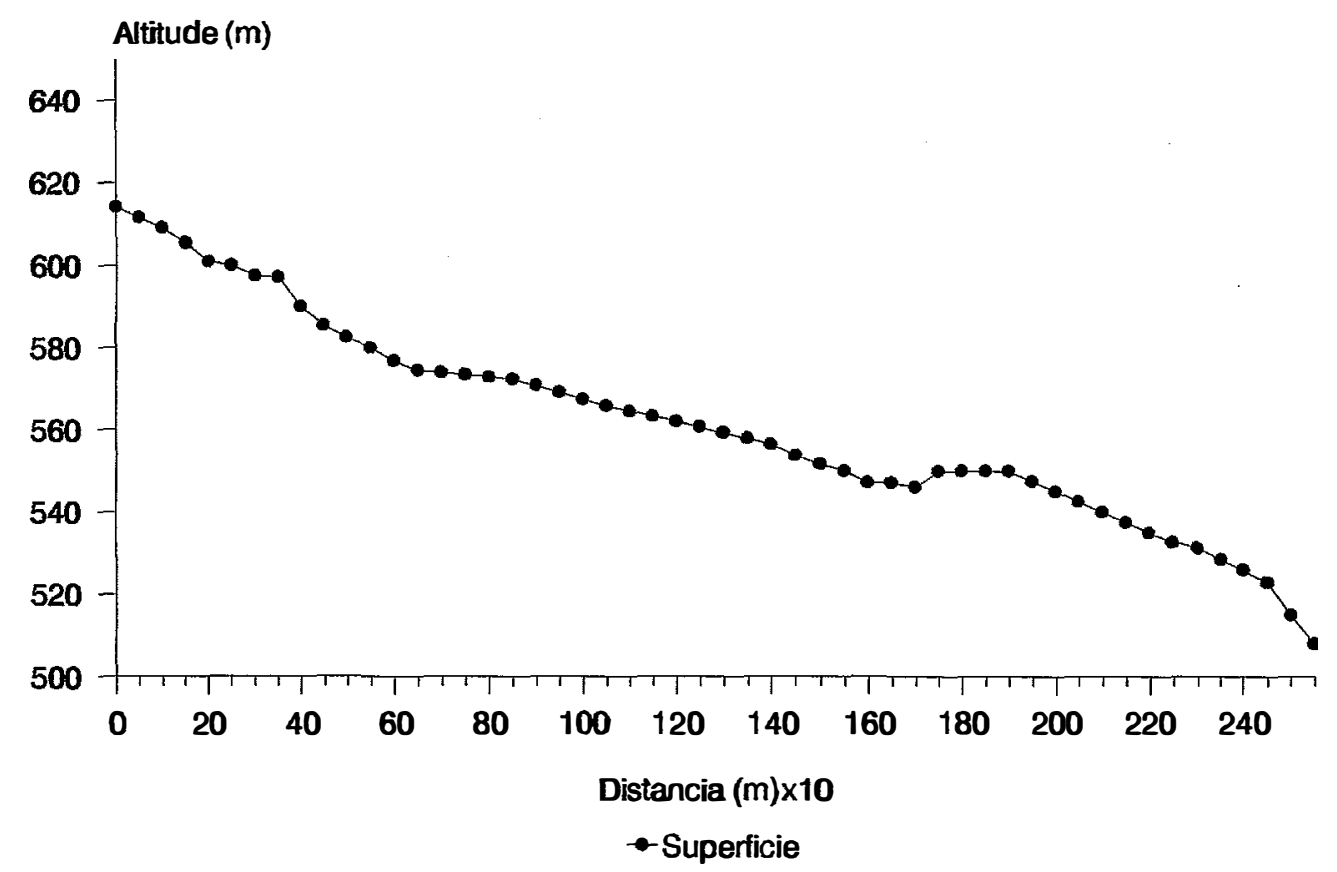

Figura 18: Perfil topográfico da transeção 2. 

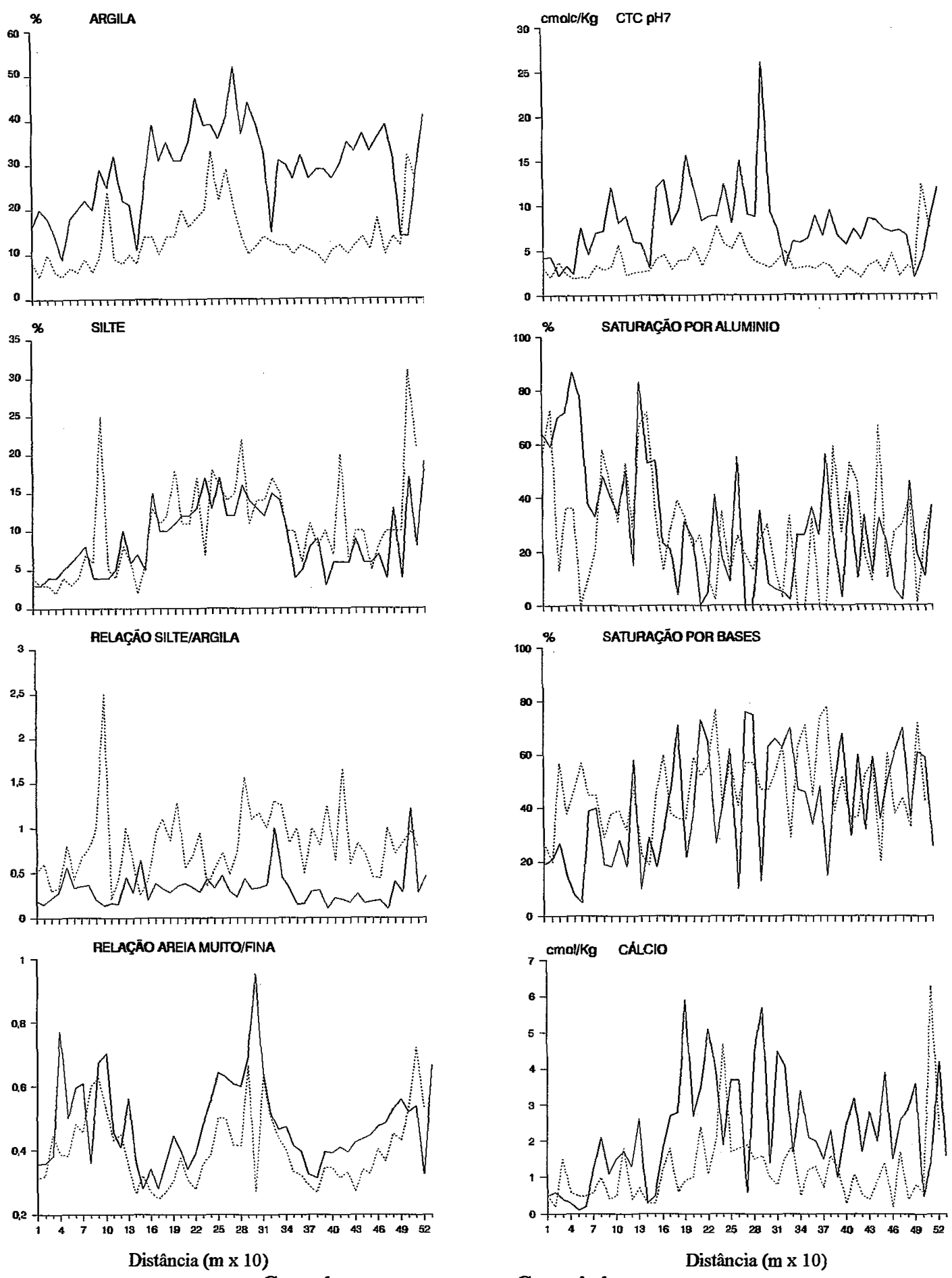

Camada a

Camada b

Figura 19: Gráficos de alguns atributos químicos e físicos da transeção 2 , em duas camadas. 


\subsubsection{Atributos químicos}

De acordo com a figura 19 os valores de V\% apresentam grande variação entre pontos tanto na camada superficial como na subsuperficial, mas no geral existe uma tendência de incremento ao longo da transeção em ambas camadas. A variação dos valores entre pontos vizinhos é muito grande, como é o caso dos pontos 27 e 28 que possuem respectivamente 10 e $76 \%$ de saturação por bases.

A saturação por alumínio tem comportamento inverso ao $\mathrm{V} \%$, diminuindo ao longo da vertente, tanto na camada a como na $\mathrm{B}$, mas mostram uma variação muito grande de valores.

A CTC pH 7 apresenta uma dispersão de valores muito grande, sendo difícil verificar o comportamento desse atributo ao longo da transeção, e isso é verificado tanto na camada a como na b, mas os valores da segunda camada são sempre mais elevados que na primeira. Os valores são sempre abaixo de $20 \mathrm{meq} / 100 \mathrm{~g}$ TFSA, apenas um ponto apresentou valor superior a $25 \mathrm{meq} / 100 \mathrm{~g}$ TFSA.

\subsubsection{Atributos físicos}

De acordo com a figura 19 o teor de argila em ambas camadas segue um acréscimo no sentido do declive, no entanto o teor de argila na segunda camada é sempre maior. A relação silte/argila não mostra variações significativas em ambas camadas ao longo da transeção.

A relação $\mathrm{AMF} / \mathrm{F}$ não aponta evidências de descontinuidade litológica, tanto na camada a como na $\mathrm{B}$. Na camada $\mathrm{b}$ a amplitude de valores por ponto é maior sugerindo talvez material mal seleciondado.

Tanto as características químicas e físicas mostram um aumento de valores entre os pontos 15 e 33. A relação silte/argila apresenta valores mais baixos na transeção 1 comparativamente aos da transeção 2 , indicando que, no topo da área estudada, o material que deu origem ao solo deve ter sido retrabalhado.

Nesta transeção o toor de cálcio, argila e silte apresentam valores relativamente mais elevados na região mediana da transeção. Nesta região o comportamento da relação AMF/F sugere mudança de material de origem, justamente onde 
foi verificada a falha geológica (Figura 7). Esses dados vem reforçar a presença da falha geológica constatada primeiro no campo.

As transeçãos mostraram de forma satisfatória a variação lateral dos solos, mesmo numa seqüência com materiais de origem diferentes, concordando com PENTEADO, (1974); GERRARD (1981), e HALL (1983) que alertam para a importância da heterogeneidade do meio na diferenciação dos solos e demostra que essas diferenças não são apenas morfológicas mas químicas e físicas também.

\subsection{Relações solo - substrato geológico - superfícies geomórficas}

Tratando-se basicamente este estudo de uma topolitofunção (JENNY, 1941; BUOL et al., 1980), o objetivo foi procurar responder a algumas questões fundamentais tais como: como é a interação das superficies geomórficas com o substrato geologico?; como os solos variam em função das diferentes litologias, ou seja, em função do fator material de origem? e como é a interação dos solos em relação as superficies geomórficas, ou seja, em relação ao tempo e relevo?.

As interações entre os solos, a geologia e a geomorfologia foram estabelecidas cruzando-se as informações dos mapas temáticos entre si, cujo resultado é a relação geográfica dos solos, do substrato geológico e das superfícies geomórficas. Esta metodologia pode ser melhor observada na Figura 20. Os atributos químicos e físicos quantificados foram submetidos a uma análise estatística, importante para que as diferenças atribuidas entre as superfícies não ficassem expostas apenas de forma qualitativa, e também para que se possa comprovar de forma inequívoca a existência de uma relação tempo espacial entre os solos e seus atributos, a geologia e a geomorfologia.

A interpretação dessas interrelações baseou-se bastante na homogeneidade das superfícies geomórficas em relação aos tipos de solos e ao material geológico existentes em cada uma delas, e da mesma forma para geologia em relação aos solos. Como a homogeneidade é um conceito relativamente subjetivo, podendo cada pessoa interpretar de forma diferente, foi concebido um valor numérico para comparar o grau de homogeneidade do objeto estudado, em relação a um fator ou uma variável qualquer, denominado aqui de "índice de homogeneidade". 
Mapa Geológico

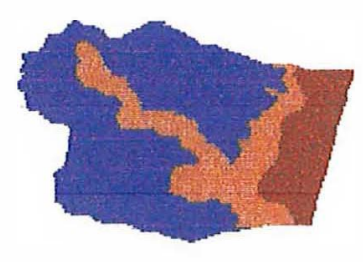

Mapa de Solos

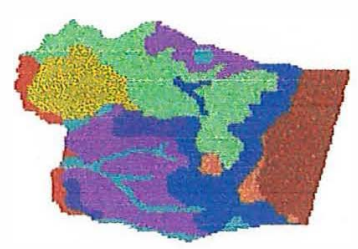

Mapa de Supefícies Geomórficas

Figura 20: Esquema apresentando os diferentes mapas temáticos. A partir destes mapas é possível, à primeira vista, tecer algumas relações entre os solos, a litologia e as superficies geomórficas. 


\subsection{1. Índice de homogeneidade}

Para contornar a aparente subjetividade dos trabalhos de relações solopaisagem, que utilizam métodos qualitativos para para comparação da homogeneidade e/ou frequência das superfícies geomórficas em termos de solos, foi desenvolvido aqui um índice quantitativo. Este índice equivale a uma média ponderada das ocorrências dos fatores estudados sendo que o peso é o próprio valor da ocorrência destes fatores.

Matematicamente foi definido como sendo a somatória dos quadrados das porcentagens das ocorrências dos fatores considerados, dividido por 100 para ser também expresso em termos percentuais. A equação é descrita a seguir:

$$
I \%=(F)^{2} / 100
$$

onde:

$\mathbf{I} \%$ = índice de homogeneidade em porcentagem

$\mathbf{F}=$ porcentagem de ocorrência do fator

O valor da ocorrência (F) foi elevado ao quadrado por que dessa forma o peso de cada fator é o valor de sua própria ocorrência, assim o fator de maior ocorrência dentro da superfície geomórfíca terá maior peso, obedecendo assim o comportamento de uma função quadrática. Nota-se que quanto menor o valor de $\mathrm{F}$, menor será o incremento após ser elevado ao quadrado e vice-versa. No caso de números decimais menores que 1 (um), não haverá incremento, ou seja, o valor de $\mathrm{F}$ após ser elevado ao quadrado será menor que o original.

Foram utilizados dois tipos de índices: o pedológico e o litológico. O pedológico permite comparar a homogeneidade das superficies geomórficas e das formações geológicas quanto aos tipos de solos. $\mathrm{O}$ índice litológico avalia a homogeneidade das superficies em termos de material geológico.

Segundo MURRAY (1985) números índices podem ser utilizados para mostrar as variações geográficas de uma variável, ou de um grupo delas, correlacionadas no tempo, à localização geográfica e a muitas outras características. RODRIGUES (1988) 
também utiliza números índices relacionados a ocorrência ou frequência de um determinado fator em fitossociologia.

Considerando que os fatores A, B e C sejam ocorrências relativas de diferentes áreas de unidades de mapeamento em diferentes superfícies geomórficas, tornase mais fácil comparar as superfícies quanto a homogeneidade em termos de solos utilizando o índice de homogeneidade proposto, no caso índice pedológico.

\subsubsection{Relações substrato geológico-superfícies geomórficas}

As formas do relevo normalmente estão relacionadas com o material geológico, principalmente no caso das superfícies mais recentes. Na área de estudo foi possível relacionar as superfícies geomórficas com a geologia local, o que tornou o entendimento do relevo mais fácil. Essa relação evidentemente não se restringe apenas ao entendimento do relevo, mas também a outras características, cujos comportamentos poderão ser assim explicados.

A tabela 4 mostra que a superficie geomórfica I está totalmente sobre a cobertura neo-cenozóica, as superfícies II e III estão assentadas sobre os arenitos da formação Pirambóia, enquanto as superfícies IV, V e V dep, estão sobre os siltitos da formação Corumbataí e em menor escala sobre alúvios-colúvios. Essa é basicamente uma relação entre a estratigrafía o tempo e o relevo local.

A geologia da área dá subsídios para explicar de forma adequada o relevo local. A superfície I está sobre o manto espesso e poroso, com boa infiltração de água e alta resistência à erosão, por isso o relevo é quase plano e a superfície é a mais antiga. $\mathrm{O}$ arenito é mais permeável que os siltitos, são mais friáveis e de mais fácil intemperização, e não raro apresentam espessas camadas alteradas, em saprolito. Esse material, de esculturação relativamente fácil , conferiu à superfície II e III formas mais suaves. As superficies IV e V possuem as maiores declividades da área, justamente porque os siltitos e folhelhos, quase impermeáveis, proporcionam maior escorrimento superficial e consequentemente maior erosão, causando intenso ravinamento, que se aprofunda formando escarpas e encostas declivosas, características das superfícies IV e V. 
Tabela 4: Porcentagem de ocorrência e indices de homogeneidade litológico dos substratos geológicos de acordo com as respectivas superfícies geomórficas (porcentagem em relação à área da superfícies).

\begin{tabular}{|c|cccc|c|}
\hline & \multicolumn{4}{|c|}{ SUBSTRATO GEOLÓGICO (\%) } & I \% \\
SUPERFÍCIE & $\begin{array}{c}\text { Alúvio/ } \\
\text { GEOMóRFICA }\end{array}$ & $\begin{array}{c}\text { Cobertura } \\
\text { colúvio }\end{array}$ & $\begin{array}{c}\text { Formação } \\
\text { cenozóica }\end{array}$ & Pormação & Fónia \\
litológico & Corumbataí & \\
\hline I & & 100,0 & & & 100,0 \\
II & & & 100,0 & & 100,0 \\
III & & & 92,7 & 7,2 & 86,4 \\
IV & & & 8,6 & 91,3 & 84,1 \\
V & 17,0 & & 1,2 & 81,8 & 70,0 \\
V dep & 4,0 & & & 96,3 & 93,0 \\
\hline
\end{tabular}

Como a cobertura neo-cenozóica está na cota mais elevada, seu topo constitui a superficie I. Já a superfície II está sobre arenitos da formação Pirambóia porque esta formação está abaixo da cobertura neo-cenozóica. A superficie III também tem grande parte nesta formação em virtude da falha geológica existente e do mergulho das camadas. Por essa razão os solos das suprfícies I, II e III são de textura máedia e os das suprfícies IV e V são argilosos.

A sequência temporal das superficies geomórficas não apresenta correlação com a sequência cronológica da coluna estratigráfica. A superficie I, mais velha, corresponde a cobertura neo-cenozóica que, como já foi visto, é posterior às duas formações Pirambóia e Corumbataí. A superfície V deposicional, mais jovem, corresponde ao material geológico mais recente, ou seja, aos alúvios-colúvios. O material geológico mais antigo, a formação Corumbataí, corresponde em grande parte à superfície IV. 


\subsubsection{Relações solos-substratos geológicos}

A geologia, ou o material de origem é um dos principais fatores de formação dos solos (BIRKELAND, 1984) portanto uma relação entre eles também foi feita para verificar como os solos variam em função do material de origem. Os resultados estão na tabela 5 .

O material geológico mais homogêneo em termos de solos é a cobertura neo-cenozóica, representada principalmente pelo Latossolo Vermelho-Amarelo, o que de certa forma é esperado. A formação Pirambóia é a segunda em termos de homogeneidade de solos e mostrou predomínio de Podzólicos Vermelho-Amarelos que perfazem em conjunto $85 \%$, com grande participação da unidade PV3. A formação Corumbatai é constituida basicamente pelos solos pouco desenvolvidos como os Litólicos e Cambissolos, sendo que os primeiros predominam, havendo também áreas de solos podzólicos. É a formação que mostrou a maior variedade de tipos de solos, apresentando portanto o menor valor de $1 \%$ pedológico (Tabela 5 ). Nos alúvios-colúvios foram encontrados apenas solos litólicos e cambissolos, e isso fez com que o I\% pedológico dos alúvios-colúvios fosse maior que a formação Corumbataí, apesar da grande heterogeneidade característica dos materiais coluviais.

Tabela 5: Porcentagem de ocorrência e índice de homogeneidade pedológico dos solos de acordo com os respectivos substratos geológicos (porcentagem em relação à área do substrato geológico).

\begin{tabular}{|c|cccccccccc|c|}
\hline & \multicolumn{7}{|c|}{ SOLOS (\%) } & I\% \\
$\begin{array}{c}\text { SUBSTRATO } \\
\text { GEOLÓGICO }\end{array}$ & LV & PV1 & PV2 & PV3 & PV4 & Cb1 & Cb2 & Li1 & Li2 & Li3 & pedológico \\
\hline Alúvios-colúvios & & & & & & 3,4 & 17,8 & 43,8 & 25,6 & 10,0 & 30,2 \\
Cob. cenozóica & 96,3 & & 1,9 & 1,8 & & & & & & & 92,8 \\
Fm. Pirambóia & 5,6 & 8,2 & 7,6 & 57,3 & 12,6 & & & 6,6 & 0,8 & 1,3 & 36,4 \\
Fm. Corumbataí & & 3,4 & & & 11,8 & 5,5 & 0,8 & 33,8 & 8,6 & 36,9 & 27,6 \\
\hline
\end{tabular}


A relação que existe entre substrato geológico e tipos de solos é bastante clara neste trabalho. A homogeneidade do substrato geológico, aliado ao relevo, condicionam a variedade de solos que são encontrados. A variabilidade dos atributos químicos e físicos dos solos são influenciados principalmente pela natureza química e física do material de partida, enquanto as características morfológicas são determinadas principalmente pelo relevo. Isso também foi verificado por AZOLIN et al., (1975); PEREZ FILHO, (1980) e BERG et al., (1987).

Dessa forma, no manto espesso, poroso e homogêneo em termos químicos e físicos, situado em relevo plano na superficie I, predomina apenas um tipo de solo. Na formação Pirambóia, o relevo suave ondulado e a homogeneidade textural originam solos morfologicamente semelhantes, ou seja, predomina uma única classe de solo, no caso o Podzólico Vermelho-Amarelo, mas o material desta formação não deve ser muito homogêneo do ponto de vista químico e físico, por isso existem 4 unidades de mapeamento da mesma classe de solo, mas no entanto todos esses solos são arenosos nos horizontes mais superficiais, estando de acordo com o material geológico subjacente.

A área correspondente à formação Corumbataí possui mais de uma classe de solo (litólicos e cambissolos), o relevo declivoso provavelmente condiciona solos morfologicamente diferentes, e a variedade do material de origem (siltitos, folhelhos) proporciona aos solos características químicas e físicas distintas. Essa relação mostra que na cobertura neo-cenozóica os solos devem possuir textura média, na formação Pirambóia devem predominar solos arenosos e na formação Corumbataí deve predominar solos argilosos.

Dessa forma, utilizando a relação superficies geomórficas-material de origem tem-se que os solos da superficie I devem realmente ser de textura média, os solos das superficies II e III ser arenosos e os solos das superfícies IV e V devem ser argilosos.

\subsubsection{Relações solos-superfícies geomórficas}

Após a separação das superfícies geomórficas e dos solos procurou-se estabelecer as relações geográficas existentes entre eles. A tabela seguinte mostra a ocorrência de cada solo em porcentagem da superfície em que ocorrem assim como o índice de homogeneidade de cada superficie em relação aos solos. 
Pela tabela 6 comparando os índices de cada superfície verifica-se que a superficie geomórfica mais homogênea em termos de solos é a superfície I, que tem 93,9\% de sua área ocupada por uma unidade simples de mapeamento, correspondente à classe do Latossolo Vermelho-Amarelo, o que concorda tanto com a relação superfície geomórfica-substrato geológico (tabelas 5), como material de origem-unidade de solo (tabela 5) apresentando substrato geológico e solos únicos, e a menos homogênea é a superficie V deposicional. As superfícies IV e $\mathrm{V}$ se equivalem em relação a homogeneidade. A superfície III, é a que possui maior quantidade de tipos de solos, e essa variedade pode ser explicada pela variedade de substratos geológicos, pois estão presentes solos derivados tanto de arenitos como de folhelhos, apesar do arenito ser predominante. Já nas superfícies IV e V. O substrato geológico é constituido basicamente por folhelhos da formação Corumbataí, que aliado ao relevo ondulado é responsável pela variedade dos solos. A superfície $\mathrm{V}$ deposicional é constituida pelos solos derivados de folhelhos e dos sedimentos coluviais e aluviais.

Tabela 6: Porcentagem de ocorrência e indice de homogeneidade pedológico dos solos de acordo com as respectivas superfícies geomórficas (porcentagem em relação à área da superfícies).

\begin{tabular}{|c|c|c|c|c|c|c|c|c|c|c|c|}
\hline \multirow{2}{*}{$\begin{array}{c}\text { SUPERFÍCIE } \\
\text { GEOMÓRFICA }\end{array}$} & \multicolumn{10}{|c|}{ SOLOS (\%) } & \multirow{2}{*}{$\begin{array}{c}\text { I\% } \\
\text { pedológico }\end{array}$} \\
\hline & $\mathbf{L V}$ & PV1 & PV2 & PV3 & PV4 & Cb1 & Cb2 & Li1 & Li2 & Li3 & \\
\hline $\mathbf{I}$ & 93,9 & & 1,8 & 1,7 & & & & & & & 88,2 \\
\hline II & 31,9 & & 22,6 & 43,1 & & & & & & & 33,9 \\
\hline III & 1,2 & 9,9 & 5,3 & 49,3 & 16,7 & & & 9,1 & 1,3 & 4,2 & 29,4 \\
\hline IV & & 5,0 & & 7,5 & 9,4 & 0,1 & & 29,4 & 4,7 & 41,3 & 27,6 \\
\hline $\mathbf{V}$ & & 1,2 & & & 7,5 & 3,4 & 5,4 & 40,2 & 12,9 & 29,2 & 27,3 \\
\hline $\mathbf{V}$ dep & & & & & 18,4 & 30,3 & 5,0 & 22,9 & 5,1 & 5,9 & 15,3 \\
\hline
\end{tabular}


A relação que existe entre solos e superficies geomórficas é representada pela tendência de que quanto mais velha e estável é a superficie mais homogênea ela deve ser em relação aos solo que nela ocorrem, ou seja, a complexidade e variabilidade de solos é inversamente proporcional à idade da superfície. A variação dos solos, assim como a estabilidade geomórfica das superfícies, está estreitamente ligada ao tempo e ao relevo. As superfícies geomorfologicamente mais estáveis oferecem condições para um maior desenvolvimento dos solos, resultando em solos mais estáveis também, é o caso da superfície I. Superfícies menos estáveis possuem normalmente solos menos desenvolvidos e mais variados. Vários autores também observaram esta tendência (LEPSCH, 1977; UBERTI \& KLANT, 1983; VIDAL-TORRADO, 1994; COELHO et al., 1994)

Os solos presentes nas diferentes superfícies estão de acordo com o tipo de substrato rochoso (tabelas 5 e 6 ), ou seja, relações entre solos e superfícies geomórficas é também uma consequência das variações litológicas, umạ vez que o material de origem é o principal fator determinante do relevo da distribuição dos solos nas superficies.

\subsubsection{Análise estatística}

Para as principais características químicas e físicas, foi feita uma análise de variância para comparação das médias desses atributos em relação às superficies geomórficas. Para isso foi utilizado o teste Tukey ao nível de significância de $95 \%$ e utilizou-se para essa análise o programa estatístico "Statgrafics". Essa análise foi feita para amostras coletadas nas camadas a e b. Foram amostrados um total de 191 pontos, sendo 20 na transeção 1, 52 na transeção 2 e 119 ao acaso. As amostras somaram um total de 376 distribuidas entre as camadas a e b conforme indicado na Tabela 7 .

Todos os parâmetros analisados mostraram diferença significativa em ambas camadas ao nível de $5 \%$, com escessão dos parâmetros $\mathrm{pH} \mathrm{KCl}$, sódio $\left(\mathrm{Na}^{+}\right)$e relação areia muito fina/fina (AMF/F). Isso mostra que os solos das superfícies diferem significativamente entre si em relação as característricas químicas e físicas. 
Tabela 7: Distribuição das amostras nas superfícies geomórficas por camada amostrada.

\begin{tabular}{|c|cccccc|c|}
\hline & \multicolumn{5}{|c|}{ SUPERFÍCIE GEOMÓRFICA } & \\
CAMADA & I & II & III & IV & V & VI & TOTAL \\
\hline a & 42 & 9 & 74 & 41 & 16 & 9 & 191 \\
b & 43 & 9 & 72 & 37 & 15 & 9 & 185 \\
\hline
\end{tabular}

\subsubsection{Camada a}

A tabela 8 mostra que na camada a, as análises estatísticas não mostraram diferenças significativas entre as superfícies I, II e III para os atributos $\mathrm{pH} \mathrm{H}_{2} \mathrm{O}$, $\mathrm{Ca}^{+2}, \mathrm{SB}, \mathrm{CTC} \mathrm{pH}$ 7, M.O., argila, silte e areia muito fina. As superficies IV, V e Vd também não se mostraram diferentes entre si em relação a estas mesmas características. Entretanto o grupo de superficies I, II e III é diferente do grupo de superfícies IV, V e Vd.

A saturação por bases (V\%) e por alumíno ( $\mathrm{m} \%)$ indicam a mesma tendência geral anteriormente citada, mas evidenciam a superficie I como diferente das demais. Os teores de $\mathrm{Ca}^{+2}$ são bastante elevados nas superfícies IV e $\mathrm{V}$ provavelmente devido ao material geológico da formação Corumbataí. Esse fato reflete-se na saturação por bases e CTC também com valores elevados. $\mathrm{O}$ teor de $\mathrm{Na}^{+}$não mostra diferenças significativas, mas nas superfícies $\mathrm{V}$ e Vd os valores médios são bem maiores, o que pode ser explicado pela posição deposicional que estas ocupam na paisagem.

As superfícies I, II e III possuem em média maior quantidade de areia muito fina e de areia total. As superficies I e II tem menor teor médio de silte que a III, apesar dessas três superfícies não serem significativamente diferentes. A superfície II deve ter influência do material da superfície I, e a III deve ter alguma contribuição do material da formação Corumbataí. O teor de argila é maior nas superficies IV e V. A relação silte/argila, também usada como índice de intemperismo, está de acordo com a sequência cronológica das superfícies, ou seja, a superfície I, mais antiga, possui menor relação e assim sucessivamente até a mais jovem que possui maior valor na relação silte/argila, porque a quantidade de silte aumenta da superfície I para a V.

Apesar de não ser estatisticamente significativa a diferença que existe entre as superficies quanto ao atributo relação textural (b/a), existe uma distinção entre as 
superfícies I, II e III, que possuem solos arenosos com diferença textural entre horizontes e portanto valores b/a maiores e as superfícies IV e $\mathrm{V}$ que possuem solos argilosos. $\mathrm{Na}$ camada a, as superficies II e I, nesta ordem, apresentaram os menores coeficientes de variação (CV) para os atributos analisados, já as superfícies $\mathrm{V}$ e $\mathrm{V}$ deposicional apresentaram os maiores coeficientes de variação. Isso mostra que a dispersão dos dados em relação à média é menor nas superficies I e II e maior na $\mathrm{V}$, ou seja, a variabilidade dos atributos dos solos é maior nestas duas últimas superficies.

\subsubsection{Camada b}

Da mesma forma que na primeira camada, os dados da camada $b$ mostram que para alguns parâmetros como $\mathrm{pH} \mathrm{H}_{2} \mathrm{O}, \mathrm{Ca}^{+2}$, areia total e silte, as superficies I, II e III não diferem estatisticamente entre si, mas diferem das superfícies IV e V.

A superfície I, no exemplo da camada a, é significativamente diferente das outras superfícies, mas não difere da II em nenhum parâmetro analisado, o mesmo acontece com a II em relação a III. Os teores de $\mathrm{Ca}^{+2}$, elevam-se a partir da superfície IV, concordando com a mudança de material de origem, de arenito para siltito. A superficie III parece sofrer certa contribuição do siltito pois apresenta teor intermediário de $\mathrm{Ca}^{+2}$. Entretanto a soma de bases parece não ter sofrido acréscimo significativo nesta superfície em função desse teor de $\mathrm{Ca}^{+2}$ e conserva a tendência de semelhança para as superfícies I, II III. $\mathrm{O}$ teor de $\mathrm{Na}^{+}$seguiu a mesma tendência da camada a, ou seja, ocorreu grande aumento de teores nas superfícies deposicionais IV e V. A matéria orgânica (MO) apresenta aumento no sentido da superfície mais velha para a mais jovem. A saturação por bases (V\%) mostrou-se baixa nas três primeiras superficies, em função do material de origem também mais pobre em bases. A saturação por alumínio ( $\mathrm{m} \%)$ apresentou comportamento inverso ao $\mathrm{V} \%$, sendo que as médias das superfícies não diferiram muito. Comportamento semelhantes quanto às características químicas foram encontradas por SANS et al., (1979); PERES FILHO et al. (1980), COOPER et al., (1993); VIDAL-TORRADO (1994) e COELHO et al. (1994).

Em relação à quantidade de areia as superfícies I, II e III não diferiram entre si, indicando que são mais arenosas em relação as demais e concordando com o arenito presente sob estas superfícies. $O$ silte ressaltou bem a influência do material de origem nas superfícies em relação aos solos. Os solos derivados de arenito ou da cobertura 
pedimentar, situados nas superficies I, II e III, apresentam teores mais baixos de areia em relação aos solos originados de siltitos e folhelhos das superficies IV e V. Já o teor de argila mostrou que a superfície I e II possuem teores semelhantes, enquanto que a superfície III assemelha-se mais às superfícies IV e V. Isso é uma evidência de que pode existir algum tipo de contribuição dos sedimentos da formação Corumbataí nas características dos solos da superficie III e explica as tendências de alguns atributos como a SB e a CTC $\mathrm{pH} 7$, que mostraram valores intermediários entre as superficies I e II e IV e $\mathrm{V}$.

A relação silte/argila evidenciou mais uma vez que os solos mais intemperizados estão na superfícies mais antigas e os menos intemperizados estão nas superficies mais jovens, como foi também observado por LEPSCH et al. (1977), entre vários outros autores.

$\mathrm{Na}$ camada b , a superfície I apresentou os menores coeficientes de variação, seguido da superfície II. Os maiores valores de coeficientes de variação foram verifiados para as superfícies IV e $\mathrm{V}$ respectivamente. Da mesma maneira que na camada a, a maior dispersão dos dados foi verificado nas superfícies mais jovens. 
Tabela 8: Médias de alguns atributos químicos e físicos da camada a em cada superfície geomórfica. Letras iguais indicam que as médias não diferem ao nível de $5 \%$ pelo teste Tukey.

\begin{tabular}{|c|c|c|c|c|c|c|c|c|c|c|c|}
\hline \multirow[b]{2}{*}{$\begin{array}{l}\text { Superfície } \\
\text { Geomórfica }\end{array}$} & \multirow[b]{2}{*}{$\begin{array}{r}\text { pH } \\
\mathbf{H} 20\end{array}$} & \multicolumn{3}{|c|}{$\mathrm{mmol}_{\mathbf{c}} / \mathrm{Kg}$} & \multicolumn{3}{|c|}{$\mathbf{g} / \mathbf{k g}$} & \multicolumn{3}{|c|}{$\mathbf{g}_{\mathbf{g}} \mathbf{k g}$} & \multirow[b]{2}{*}{$\begin{array}{l}\text { Silte/ } \\
\text { Argila }\end{array}$} \\
\hline & & $\mathrm{Ca}^{+2}$ & SB & $\begin{array}{l}\text { CTC } \\
\text { pH7 }\end{array}$ & MO & $\mathbf{V}$ & m & $\begin{array}{l}\text { Areia } \\
\text { M.F. }\end{array}$ & Silte & Argila & \\
\hline I & $4,6^{b}$ & $9^{b}$ & $13^{b}$ & $3,8^{b}$ & $1,2^{b}$ & $32^{\mathrm{d}}$ & $41^{\mathrm{ac}}$ & $16^{\mathrm{a}}$ & $3^{d}$ & $11^{b}$ & $0,3^{\mathrm{c}}$ \\
\hline II & $5,1^{b}$ & $8^{b}$ & $12^{b}$ & $3,0^{b}$ & $1,1^{b}$ & $41^{\mathrm{cd}}$ & 24 cde & $19^{\mathrm{a}}$ & $3^{d}$ & $9^{b}$ & $0,4^{b c}$ \\
\hline III & $4,9^{\mathrm{b}}$ & $15^{b}$ & $22^{b}$ & $5,0^{b}$ & $1,2^{b}$ & $45^{\mathrm{bc}}$ & $27^{b c d}$ & $18^{\mathrm{a}}$ & $10^{b d}$ & $15^{b}$ & $0,7^{\mathrm{ab}}$ \\
\hline IV & $5,3^{\mathrm{a}}$ & $45^{\mathrm{a}}$ & $63^{\mathrm{a}}$ & $9,6^{\mathrm{a}}$ & $2,3^{a}$ & $62^{\mathrm{a}}$ & $9^{c}$ & $12^{b}$ & $22^{\mathrm{a}}$ & $26^{\mathrm{a}}$ & $0,9^{\mathrm{ab}}$ \\
\hline $\mathbf{V}$ & $5,5^{\mathrm{a}}$ & $50^{\mathrm{a}}$ & $73^{a}$ & $12,1^{\mathrm{a}}$ & $2,2^{\mathrm{a}}$ & $61^{\mathrm{ac}}$ & $12^{\mathrm{de}}$ & $11^{b}$ & $22^{\mathrm{a}}$ & $27^{\mathrm{a}}$ & $0,9^{\mathrm{a}}$ \\
\hline $\mathbf{V d}$ & $5,1^{\mathrm{ab}}$ & $56^{\mathrm{a}}$ & $71^{a}$ & $12,3^{\mathrm{a}}$ & $2,2^{\mathbf{a}}$ & $42^{\mathrm{cd}}$ & $39 \mathrm{abc}$ & $13^{\mathrm{ab}}$ & $19^{\mathrm{a}}$ & $24^{\mathrm{a}}$ & $0,8^{\mathrm{a}}$ \\
\hline
\end{tabular}

Tabela 9: Coeficientes de variação (\%) de alguns atributos químicos e físicos da camada a em cada superfície geomórfica.

\begin{tabular}{|c|ccccccccccc|}
\hline $\begin{array}{c}\text { Superfície } \\
\text { Geomórfica }\end{array}$ & $\begin{array}{c}\text { pH } \\
\text { H2O }\end{array}$ & $\mathbf{C a}^{+2}$ & SB & $\begin{array}{c}\text { CTC } \\
\text { pH7 }\end{array}$ & MO & V & m & $\begin{array}{c}\text { Areia } \\
\text { M.F. }\end{array}$ & Silte & Argila & $\begin{array}{c}\text { Siltel } \\
\text { Argila }\end{array}$ \\
\hline I & 15 & 94 & 94 & 31 & 24 & 57 & 61 & 33 & 46 & 30 & 69 \\
II & 8 & 48 & 44 & 41 & 19 & 29 & 74 & 25 & 30 & 58 & 56 \\
III & 13 & 99 & 88 & 84 & 40 & 38 & 80 & 28 & 17 & 56 & 56 \\
IV & 9 & 65 & 62 & 52 & 52 & 26 & 140 & 47 & 49 & 50 & 29 \\
V & 20 & 73 & 77 & 96 & 45 & 37 & 174 & 64 & 54 & 60 & 56 \\
Vd & 18 & 191 & 159 & 86 & 75 & 66 & 68 & 36 & 44 & 37 & 43 \\
\hline
\end{tabular}


Tabela 10: Médias de alguns atributos químicos e físicos da camada $b$ em cada superfície geomórfica. Letras iguais indicam que as médias não diferem ao nível de $5 \%$ pelo teste Tukey.

\begin{tabular}{|c|c|c|c|c|c|c|c|c|c|c|c|}
\hline \multirow[b]{2}{*}{$\begin{array}{l}\text { Superficie } \\
\text { Geomórfica }\end{array}$} & \multirow[b]{2}{*}{$\begin{array}{r}\text { pH } \\
\mathbf{H 2 O}\end{array}$} & \multicolumn{3}{|c|}{ [mmol ${ }_{\mathbf{c}} \mathbf{K g}$} & \multicolumn{3}{|c|}{ g/kg } & \multicolumn{3}{|c|}{ _g/kg } & \multirow[b]{2}{*}{$\begin{array}{c}\text { Silte/ } \\
\text { Argila }\end{array}$} \\
\hline & & $\mathrm{Ca}^{+2}$ & SB & $\begin{array}{l}\text { CTC } \\
\text { pH7 }\end{array}$ & MO & $\mathbf{V}$ & $\mathbf{m}$ & $\begin{array}{l}\text { Areia } \\
\text { Total }\end{array}$ & Silte & Argila & \\
\hline I & $4,5^{b}$ & ${ }_{11} \mathrm{c}$ & $14^{\mathrm{cd}}$ & $4,4^{\mathrm{C}}$ & $0,9^{\mathrm{cd}}$ & $30 \mathrm{c}$ & $46^{\mathrm{abc}}$ & $14^{a}$ & $4^{c}$ & $22^{b c}$ & $0,18^{\mathrm{C}}$ \\
\hline II & $4,3^{b}$ & $07^{\mathrm{C}}$ & $10^{d}$ & $4,9 \mathrm{bc}$ & $0,8^{d}$ & $21^{c}$ & $62^{\mathrm{ab}}$ & $74 \mathrm{ab}$ & $5^{b c}$ & $20^{\mathrm{c}}$ & $0,28^{b c}$ \\
\hline III & $4,5^{b}$ & $26^{b c}$ & $36^{\mathrm{bd}}$ & $10,8^{b}$ & $1,0^{b c}$ & $40^{c}$ & $32^{\mathrm{bcd}}$ & $58 \mathrm{bc}$ & $9 b$ & $32^{\mathrm{ac}}$ & $0,32^{\mathrm{cb}}$ \\
\hline IV & $5,2^{\mathrm{a}}$ & $49^{a b}$ & $71^{a}$ & $12,7^{\mathrm{ab}}$ & $1,5^{\mathrm{a}}$ & $58^{\mathrm{a}}$ & $17^{d}$ & $43^{d}$ & $21^{a}$ & $36^{a}$ & $0,81^{\mathrm{ab}}$ \\
\hline $\mathbf{V}$ & $5,3^{\mathrm{a}}$ & $41^{\mathrm{ab}}$ & $63^{\mathrm{a}}$ & $17,3^{\mathrm{a}}$ & $1,3^{\mathrm{ab}}$ & $46^{b c}$ & $28^{\mathrm{cd}}$ & $50 \mathrm{~cd}$ & $16^{\mathrm{a}}$ & $33^{\mathrm{ac}}$ & $0,59^{\mathrm{abc}}$ \\
\hline $\mathbf{V} d$ & $5,4^{\mathrm{a}}$ & $43^{a}$ & $71^{a}$ & $14,4^{\mathrm{ab}}$ & $1,4^{\mathrm{ab}}$ & $50^{\mathrm{bc}}$ & $31^{\mathrm{bcd}}$ & $47 \mathrm{~cd}$ & $17^{a}$ & $35^{\mathrm{ac}}$ & $0,48^{a b c}$ \\
\hline
\end{tabular}

Tabela 11: Coeficientes de Variação de alguns atributos químicos e físicos da camada $b$ em cada superficie geomórfica.

\begin{tabular}{|c|c|c|c|c|c|c|c|c|c|c|c|}
\hline $\begin{array}{l}\text { Superficie } \\
\text { Geomórfica }\end{array}$ & $\begin{array}{r}\text { pH } \\
\text { H2O }\end{array}$ & $\mathrm{Ca}^{+2}$ & SB & $\begin{array}{l}\text { CTC } \\
\text { pH7 }\end{array}$ & MO & $\mathbf{V}$ & $\mathbf{m}$ & $\begin{array}{l}\text { Areia } \\
\text { Total }\end{array}$ & Silte & Argila & $\begin{array}{c}\text { Silte/ } \\
\text { Argila }\end{array}$ \\
\hline I & 14 & 89 & 73 & 20 & 13 & 63 & 62 & 8 & 52 & 21 & 47 \\
\hline II & 8 & 99 & 86 & 37 & 16 & 87 & 41 & 10 & 31 & 33 & 46 \\
\hline III & 13 & 60 & 63 & 79 & 26 & 56 & 79 & 25 & 60 & 32 & 65 \\
\hline IV & 10 & 67 & 68 & 61 & 53 & 38 & 117 & 59 & 49 & 51 & 136 \\
\hline V & 21 & 79 & 92 & 80 & 35 & 62 & 96 & 47 & 56 & 53 & 53 \\
\hline Vd & 10 & 89 & 77 & 64 & 18 & 51 & 80 & 48 & 67 & 38 & 63 \\
\hline
\end{tabular}




\subsubsection{Comentários gerais sobre as camadas a e b}

Tanto a camada de solo superficial a como a subsuperficial b mostraram as mesmas tendências para os atributos analisados, ou seja, as conclusões seriam as mesmas se fosse amostrada apenas uma dessas camadas. Técnicas de geoestatística utilizadas por BERG et al. (1987) em areas aluviais revelam que na maioria dos casos, a distribuição espacial das características da camada superficial do solos independe da camada subsuperficial e em uma mesma camada de solo, a distribuição de certas características pode independer de outras da mesma camada. No entanto, o autor observa que a primeira afirmação pode estar relacionada à diversidade do material de origem e na segunda afirmação os atributos podem estar relacionados tanto ao material de origem como aos processos pedogenéticos que são específicos para os locais onde os sedimentos se depositaram.

Apesar da superficie I ser mais antiga e possuir solos mais intemperizados, a superfície II apresenta valores de soma de bases mais baixos em relação a primeira superfície. Isso pode ser explicado provavelmente pela topografia declivosa da superficie II, que resulta em intensa erosão e lixiviação das bases, fazendo com que os solos desta superfície, apesar de relativamente mais jovens, possuam menor quantidade de bases que o solo da superfície I.

A influência ou contribuição dos materiais de origem, entre as diferentes superficies, também ficou evidenciada. É o caso das superfícies I e II, cujos dados sugerem a existência de uma relação entre o material da cobertura cenozóica e o arenito Pirambóia, pois não houve diferença significativa entre as médias destas superficies em nenhum atributo e camada. Já os dados da camada b da superfície III sugere a existência de alguma relação entre o arenito e os siltitos, porque para alguns atributos desta camada os valores mostraram-se intermediários, como o teor de argila, areia total, CTC pH 7 e SB.

As superfícies I, II e III possuem vários atributos estatística e significativamente semelhantes, o mesmo acontece com as superficie IV e V. Dessa forma é possível formar dois grupos de superficies distintos. Assim o primeiro grupo seria formado pelas superficies I, II e III que contém solos de textura média e arenosos, derivados da cobertura cenozóica de textura média e de arenitos da formação Pirambóia e o segundo seria composto pelas superficies IV e V que possuem solos derivados dos siltitos e 
folhelhos argilosos da formação Corumbataí. A presença de dois grupos de superfícies geomórficas sugere a existência do que se poderia chamar talvez de dois sistemas geomorfológicos, que possuem características próprias e que são controlados principalmente pelo material de origem e pelo relevo.

No primeiro grupo de superfícies os solos são quimicamente pobres, em função principalmente da escasses de bases no material de origem (cobertura cenozóica e arenitos da formação Pirambóia). Além disso, estas superfícies ocupam relevo com declividade pouco acentuada e estão sobre materiais geológicos permeáveis, apresentando lixiviação intensa, favorecendo ainda mais a perda de bases. $\mathrm{O}$ grupo de superfícies IV e $\mathrm{V}$ possuem solos mais ricos do ponto de vista químico porque a contribuição do material de origem na fertilidade é maior em solos pouco desenvolvidos, como é o caso dos Litossolos e Cambissolos. Essa contribuição do material de origem na fertilidade do solo é decorrente dos níveis carbonáticos presentes na formação Corumbataí.

Dessa forma as variações dos atributos químicos e físicos que ocorrem entre as superfícies são, em primeira instância, principalmente decorrentes das litologias da área. Já as diferenças morfológicas dos solos encontrados podem ser atribuidas principalmente ao fator relevo dentro de cada superfície. Superficies em que o relevo é declivoso ou que apresentam variações topográficas não tão acentuadas porém frequentes, terão maiores variações morfológicas nos solos. É o caso das superfícies IV e V. Considerando-se as tendências gerais, tanto as características químicas e físicas analisadas sugerem uma tendência coerente em relação à posição que as superfícies ocupam na paisagem, ao material geológico predominante na superficie e ao tempo de formação do solo.

Os atributos dos solos apresentam menor variabilidade nas superfícies I e II, mais antigas e estáveis, e maior nas superfícies IV e V, mais jovens e menos estáveis. Essa tendência está de acordo com a geologia e a posição na paisagem. Superfícies mais antigas e geomorfologicamente mais estáveis tendem a ter menor variabilidade dos atributos químicos e físico dos solos, ao contrário, as superfícies mais jovens possuem maior variabilidade. O que está de acordo com LEPSCH, (1977) e UBERTI \& KLAMT, (1984).

A tabela 12 mostra para cada atributo, as superficies geomórficas dispostas em ordem crescente em relação aos valores médios de cada atributo. É uma tentativa de ilustrar de forma qualitativa a tendência ou o comportamento desses atributos 
na paisagem e no tempo. Mostra também, de forma mais fácil, o grupo de superfícies I, II e III, que é estatisticamente diferente do grupo de superficies IV e V. Essa divisão coincide com a mudança de material de origem e de relevo.

A afirmação de GRAHAM \& BUOL (1990) de que a natureza residual ou coluvial dos solos está relacionada com a posição geomórfica que eles ocupam na paisagem, e que em posições mais altas das encostas os solos são de origem residual (ou in situ) do que nas posições mais baixas os solos são de origem aluvio-coluvial é parcialmente confirmado neste trabalho. Os solos da superficie $\mathrm{V}$ deposicional possuem uma participação de material coluvial muito grande, em contrapartida os solos das cotas mais altas, superfície II, são residuais originados do intemperismo do arenito. Entretanto, neste rabalho, a afirmação desses autores deve ser interpretada com cautela, e provavelmente aplica-se melhor em regiões que sofreram glaciações, em que a ação das geleiras arrasaram as superficies mais antigas. Nas regiões tropicais, em que essas superficies residuais foram em grande parte preservadas, é relativamente comum a ocorrência de material pedimentar presentes nos topos e que muitas vezes é de origem coluvial (BIGARELLA et al., 1965; PENTEADO, 1976; MELO \& PONÇANO; 1983), o que é o caso da superficie I da área de estudo.

Dentro de cada superfície geomórfica os solos apresentaram variações morfológicas, e quando são derivados de folhelhos essa variação é particularmente maior. Constatou-se que essa variação ocorre em função principalmente do macro e micro relevo, ou seja, cada porção da encosta parece influenciar os solos. Isso pôde ser verificado em maior escala na unidade de mapeamento Li3 que é um complexo de solos pouco desenvolvidos. Esse fato vem de encontro às afirmações de GERRARD (1990), o qual observou que os componentes individuais das encostas possuem características de solos que parecem estar relacionados com a natureza morfológica dessas encostas, constatou ainda que as relações entre solos e a paisagem existem, mas a idéia de que elas ocorrem em toda extensão da encosta não é necessariamente verdade. Isso foi constatado na área estudada pela presença de dois grupos distintos de superfícies geomórficas que tem, cada uma, dinâmica própria dentro da paisagem e que estão na mesma encosta. 
Tabela 12: Análise qualitativa das tendências de alguns atributos químicos e físicos das camadas a e b. As superficies estão dispostas em uma ordem correspondentes aos valores dos respectivos atributo.

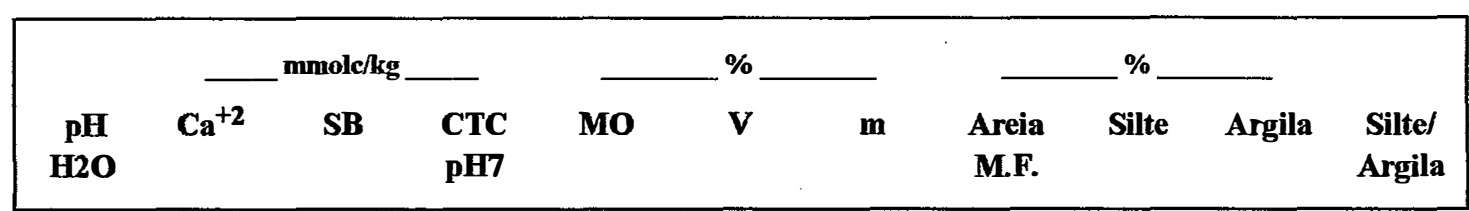

CAMADA a (0-20cm)

\begin{tabular}{|ccccccccccc|}
\hline I & II & II & II & II & I & IV & V & II & II & I \\
III & I & I & I & III & II & V & IV & I & I & II \\
II & III & III & III & I & III & II & I & III & II & III \\
\hline IV & IV & IV & IV & V & V & III & II & IV & IV & IV \\
V & V & V & V & IV & IV & I & III & V & V & V \\
\hline
\end{tabular}

CAMADA b $(60-80 \mathrm{~cm})$

\begin{tabular}{|ccccccccccc|}
\hline II & II & II & I & II & II & IV & IV & I & II & I \\
III & I & I & II & I & I & V & V & II & I & II \\
I & III & III & III & III & III & III & III & III & III & III \\
\hline IV & V & V & IV & V & V & II & I & V & V & V \\
V & IV & IV & V & IV & IV & I & II & IV & IV & IV \\
\hline
\end{tabular}




\section{CONCLUSÕES}

1. A área estudada apresenta quatro tipos de substrato geológico que influenciam a pedogênese dos solos encontrados, a saber: A cobertura Neocenozóica, os arenitos da formação Pirambóia, os siltitos, sílex e folhelhos da formação Corumbataí e os sedimentos coluviais e aluviais. A formação Corumbataí apresenta uma camada característica de sílex com espessura variando em torno de 20 a $30 \mathrm{~cm}$ e ocorre de forma quase horizontal nas cotas 575 a $580 \mathrm{~m}$ e outra camada mais descontínua, na cota $530 \mathrm{~m}$. Esta bancada é um agente controlador da declividade do relevo devido a sua grande resistência à erosão e ao intemperismo. Nos locais onde o sílex ocorre em dois níveis, o relevo apresenta a forma de dois patamares na encosta. Com o recuo das vertentes este sílex espalha-se na superfície por ação da gravidade, mas apresenta-se também esparso e espalhado na superficie plana de alguns interflúvios.

2. Como o silex controla o relevo local, as vertentes não evoluem uniformemente possuindo invariavelmente quebras de relevo devido a esse controle litológico. Dessa maneira algumas encostas não seguem os padrões ou teorias de evolução das vertentes de Davis, Penk, King ou Hack, mas parece que o modelo de King em que o topo é preservado acontece, mesmo com o recuo irregular das encostas. Tomandose a área de estudo como um todo, o modelo de BIGARELLA (1965), de alternâncias climáticas, parece ser mais adequado para explicar a paisagem, e as superficies geomórficas.

3. Foram identificadas cinco superfícies geomórficas e dez unidades de mapeamento de solos. A relação que existe entre solos e superfícies geomórficas é representada pela tendência de que quanto mais velha e estável é a superficie mais homogênea ela é em relação aos solo que nela ocorrem. Os atributos dos solos apresentam menor variabilidade nas superfícies I e II, mais antigas e estáveis, e maior nas superficies IV e V, mais jovens e menos estáveis. A análise estatística mostrou que existem dois grupos de superficies geomórficas cada um com características de geologia, solos e relevo distintos. Essa separação coincide com a mudança de material de origem de arenito para siltito. Um é formado pelas superficies 
geomórficas I, II e III e outro formado pelas superficies IV, V e Vd. Isso mostra que existem dois sistemas geomorfológicos na mesma encosta, cada um com uma dinâmica própria dentro da paisagem. Dentro de cada superfície geomórfica os solos apresentaram variações, sendo que a variabilidade morfológica dos solos foi atribuida principalmente ao fator relevo e microrelevo e a variabilidade dos atributos físicos e químicos foi influenciada principalmente pelo material de origem.

4. As transeções realizadas mostraram-se muito importantes para o estudo da variação lateral dos atributos dos solos, na identificação das mudanças de material de origem através dos dados analíticos e na constatação quantitativa da presença da falha geológica na transeção 2 . A transeção 1 foi importante para evidenciar a influência do material subjacente nas características químicas e físicas da cobertura neocenozóica.

5. Os índices de homogeneidade propostos e o sistema de cruzamento de informações através de mapas temáticos atenderam de forma bastante eficiente as suas finalidades, mostrando serem ferramentas bastante úteis em estudos que relacionem diferentes elementos da paisagem, uma vez que permitem analisar de forma simples e rápida as relações de diferentes temas.

6. O Latossolo Vermelho-Amarelo textura média está relacionado à cobertura neocenozóica e à superfície I, onde o relevo é plano. Os Podzólicos VermelhoAmarelos abruptos de textura predominantemente arenosa/média relacionam-se ao arenito da formação Pirambóia, às superfícies II e III em relevo suave ondulado. Os Litólicos argilosos estão associados aos siltitos e sílex da formação Corumbataí, às superficies IV e V em relevo ondulado e escarpado. Os Cambissolos de textura variada relacionam-se aos alúvios-colúvios presentes na superfície $\mathrm{V}$ deposicional em relevo plano a suave ondulado, no fundo dos vales e nas margens do ribeirão. Estas relações, estabelecidas na área de estudo, se repetem na paisagem de outros locais da microbacia com características de solo, relevo e litologia semelhantes a da área estuda. Isso mostra que as relações estabelecidas na área estudada podem ser extrapoladas para outras, contribuindo dessa forma para futuros levantamentos de solos que possam vir a ser realiazados nessa microbacia 


\section{REFERÊNCIAS BIBLIOGRÁFICAS}

Ab'SABER, A.N. Depressão periférica paulista: um setor de circundesnudação póscretácica na Bacia do Paraná. Universidade de São Paulo, Instituto de Geografia, São Paulo. Geomorfologia, 15, 15 p. 1969.

ALMEIDA, F.F.M. de. Fundamentos geológicos do relêvo paulista. Geologia do Estado de São Paulo, Instituto de Geografia e Geologia. p.167-263, Boletim 41, 1964.

ARNOLD, R.W. Concepts of soils and pedology. In: Pedogenesis and soil taxonomy: Concepts and Interactions, vol I. Elsevier Sci. Pub. New York, p.21, 1983.

AZOLIN, M.A.D.; KLAMT, E. \& SANTOS, M.C.C. dos. Relações solo-superfícies geomórficas e material de origem a oeste da depressão central e campanha no Rio Grande do Sul. In: Congresso Brasileiro de Ciência do Solo, 15o. Campinas, 1975, Anais, Campinas, Soc. bras. Ci. Solo, p. 345-350, 1976

BARTHELMESS, H. Zona de Piracicaba, 1958 141p. (Livre-docência - Faculdade de Filosofia Ciências e Letras, Universidade do Paraná)

BENNEMA, J.; CAMAR̆GO, M.N. \& WRIGHT, A.C.S. Regional contrast in South American soils formation in relation to soil classification and soil fertility. Trans. of Joint Meeting of Comm. IV and V Soil Conf., New Zeeland, p.493-5, 1962.

BERG, M. van den; LEPSCH, I. F. \& SAKAI, E. Solos de planícies aluviais do vale do Ribeira do Iguape: I Padrões de distribuição. Rev. bras. Ci. do Solo, Campinas, 11(2):305-313, 1987.

BICKI, T.J. \& TANDARICH, J.P. The roots of pedology: a response to "Pedology: a field or a laboratory science?". Soil Sci. Soc. Am. J., Madison, 53:1920-1921. 1989. 
BIGARELLA, J.J. \& ANDRADE, G.O. de. Contribuition to the study of the Brazilian Quaternary. Spec. ap., Geol. Soc. Am. 84: p. 433-451 1965a.

BIGARELlA, J.J.; MOUSINHO, M.R. \& SILVA, J.X. Pediplanos, pedimentos e seus depósitos correlativos no Brasil. Bol. Paran. de Geografia. Curitiba 16/17: 117-151, $1965 b$.

BIRKELAND, P.W. Soil and Geomorphology. Oxford University Press, New York EUA, 1984.

BJORNBERG, A.J.S. \& LANDIM, P.M.B. Contribuição ao estudo da formação Rio Claro, neocenozóico. Bol. Soc. bras. Geol. , São Paulo, 15 (4):43-68. 1966.

BREWER, R. Fabric and mineral analisys. Reprint of the ed. published by John Wiley \& Sons. Inc. USA, 482 p. 1976.

BRASIL Ministério da Agricultura Comissão de Solos. Levantamento de reconhecimento de solos do Estado de São Paulo. Rio de Janeiro, Ministério da Agricultura, CNEPA, 634p. 1969 (Boletim 12)

BRIGGS, D.J. \& SHISHIRA, E.K. Soil Variability in geomorphologically defined survey units in the Albudeite area of Murcia Province, Spain. Catena suplement, No. 6, p.69-84, 1985.

BUOL, S.W.; HOLE, F.D. \& MAcCRACKEN, R.J. Soil Genesis and Classification. The Iowa State University Press, Ames. 404 p., 1980.

CAMARGO, O. A. de; MONIZ, A. C.; JORGE, J. A. \& VAlADARES, J. M. A. S. Métodos de análise química, mineralógica e física de solos do IAC. Campinas, Instituto Agronômico de Campinas 49p. 1986.

CARMO, D.N.; CURI, N. \& RESENDE, M. Caracterização de latossolos da região do Alto Paranaiba (MG). Rev. bras. Ci. Solo. Campinas 8:235-240, 1984.

CASTRO, S.S. Sistemas de transformação pedológica em Marília, SP: B latossólicos e B texturais. São Paulo, Faculdade de Filosofia, Letras e Ciências Humanas da Universidade de São Paulo, 1989. 274p. (Tese de Doutoramento) 
CHAVEAU, A.; BOULET, R.; GORDON, P.; WOROU, S. \& LUCAS, Y. Enviromental characterization of acid tropical soils. Management of acid tropical soils for sustainable agriculture. Proceedings of an IBSRAM inaugural workshop, Bankok, Thailand. IBSRAM proceedings, No. 2, 217-226, 1987.

CHRISTOFOlETTI, A. \& PENTEADO, M. M. Cronologia relativa do quaternário na depressão periférica paulista. Notícia Geomorfológica, Campinas, 10(19):13-46, 1970.

CHRISTOFOLETTI, A. Mapeamentos geomorfológicos no Brasil. Geociências, São Paulo, V 2:1-6 1983.

COELHO, R. M.; LEPSCH, I. F. \& MENK, J. R. F. Relações solo-relevo em uma encosta com transição arenito-basalto em Jaú (SP), R. bras. Ci. Solo, Campinas, 18:125-137, 1994.

COOPER, M.; LEPSCH, I. F. \& VIDAL-TORRADO, P. Caracterização dos solos ao longo dos compartimentosde uma vertentesobre diabásio em Piracicaba (SP). Anais do XXIV Congresso Brasileiro de Ciência do Solo. Soc. bras. Ci. Solo. Resumos, Vol II:330. 1993.

DANIELS, R.B. Pedology, a field or a laboratory science? Soil Sci. Soc. Am. J. Madison, 52:1518-1519. 1988.

DANIELS, R.B.; GAMBLE, E.F. \& CADY, J.G. The relation between geomorphology and soil morphology and genesis. Advances in Agronomy, 23: 51-87, 1971.

DANIELS, R. B. \& HAMMER, R. D. Soil geomorphology. John Wiley \& Sons, Inc. New York, 236p., 1992.

De JONG VAN LIER, Q \& VIDAL-TORRADO, P. Phi: programa de microcomputador para análise estatística da granulometria de sedimentos. R. bras. Ci. Solo, Campinas, 16:277-281, 1992.

DEMATTÊ, J.L.I. \& HOLLAWAYCHUC Solos da região de São Pedro, Estado de São paulo. Rev. bras. Ci. Solo, Campinas 1(2-3):92-104, 1981.

EMBRAPA, Serviço Nacional de Levantamento e Conservação de Solos (SNLCS) Sistema brasileiro de classificação de solos, 3a. aproximação, Rio de Janeiro, 122p., 1988. 
EMMERICH, K. H. Influence of landform, landscape development and soil moisture balance on forest and savanna ecosystem patterns in Brazil, Pedologie, 40:1, 5-17, 1990.

ESWARAN, H. \& SYS, C. Argillic horizons in LAC soils formations and significance to classification. Pedologie, Ghent, 29: 175-190, 1979.

E.U.A. Soil Survey Staff. Soil Taxonomy: A basic system of soil classification for making and interpreting soil surveys. Agric. Handbook No. 436, Government Printing Office, Washington, D.C. 330p. 1975.

FITZPATRICK, E. A. Pedology, a systematic approach to soil science, Oliver \& Byd, 306p., 1971.

FULFARO, V.J. \& SUGUIO, K. O cenozóico paulista: gênese e idade. Anais XXVIII Cong. bras. Geol. Vol 3, Soc. bras. Geol., Porto Alegre, RS, p.91-101, 1974.

GAMA Jr., E. Concepções estratigráficas em análise de bacias Geociência, São Paulo, v. 8:1-21, 1989.

GERRARD, J. Soils and landform. An interaction of geomorphology and pedology. Allen and Uwin pub., London, 219p., 1981.

GERRARD, J. Soil variations on hillslopes in humid temperate climates. Geomorphology, 3:3/4, 225-244, 1990.

GRAHAM, R. C. \& BUOL, S. W. Soil- geomorphic relations on the Blue Ridge Front: II. Soil characteristics and pedogenesis. Soil Sci. Soc. Am. J. Madison, 54:5, 1367-1377, 1990.

GUERRA; A.J. \& CUNHA, S.B. Geomorfologia, uma atualização de bases e conceitos, Rio de Janeiro, 458p, 1994.

HALL, G. F. Pedology and Geomorphology. In: Pedogenesis and Soil Taxonomy. I. Concepts and Interactions. Elsevier Sci. Pub. New York, p. 117-140, 1983.

HALL, G. F. \& OLSON, C. G. Predicting variability of soils from landscape model. in: Spatial variabilities of soils and landform. Proceedings, International Symposium, Las Vegas, Nevada. Soil Science society of America, Special Publication no 28, Madison, Wisconsin, 1991. 
HILGARD, E.W. Soils, New York, The Macmillan Company, 586p., 1907.

IPT Mapa geológico do Estado de São Paulo. Escala 1:1.000.000. Divisão de Minas e Geologia Aplicada do Instituto de Pesquisas Tecnológicas do Estado de São Paulo. São Paulo, 1981a.

IPT Mapa geomorfológico do Estado de São Paulo. Escala 1:1.000.000. Divisão de Minas e Geologia Aplicada do Instituto de Pesquisas Tecnológicas do Estado de São Paulo. SÃo Paulo, 1981b.

JACOB, J.S. \& NORDT, L.C. Soil and landscape evolution: a paradigm for pedology. Soil Sci. Soc. Am. J., Madison, 55:1194. 1991.

JENNY, H. Factors of Soil Formation. New York, McGraw-Hill; 281p 1941.

JENNY, H. The Soil Resource, Origim and Behavior. New York, Springer Verlas editors, 376p., 1980.

JIMENEZ RUEDA, J.R. \& DEMATTÊ, J.L.I. Solos originados de lamitos da formação Marilia (grupo Bauru) da região de Monte Alto, SP.. Rev. bras. Ci. Solo, Campinas, 12: $161-170,1988$.

KAMPF, N. \& KLAMT, E. Mineralogia e Gênese de Latossolos (oxissol). Rev. bras. Ci. Solo, Campinas, 2: 68-73, 1978.

KING, L.C. A geomorfologia do Brasil Oriental. R. bras. Geogr., Rio de Janeiro, 18 (2):147-256. 1956.

LEPSCH, I.F. Superfícies geomorfológicas e depósitos superficiais neocenozóicos em Echaporã, SP. Boletim Paulista de Geografia, São Paulo, 53: 5-34, 1977.

LEPSCH, I.F. \& BUOL, S. W. Investigation in an Oxisol-Ultisol topossequence in São Paulo State, Brazil. Soil Sci. Soc. Amer. Proceedings, Madison, 38:491-496, 1975.

LOBO, A.E.M. Relações solo-superfícies físiográficas em uma transeção de Piracicaba, SP. Escola Superior de Agricultura "Luiz de Queiroz", USP, Piracicaba, 164p,1984. (Tese de Doutoramento)

MARQUES Jr, J. Litocronossequência de solos da região de Lavras (MG). Escola Superior de Agricultura de Lavras, Lavras MG, 78p., 1988. (Tese de Mestrado) 
McFADDEN, L.D. \& KNUEPFER, P.L.K. Soil geomorphology: the linkage of pedology and surficial processes. Geomorphology, 3: 3/4, 197-205, 1990.

MELO, M.S. \& PONÇANO, W.L. Gênese, distribuição e estratigrafia dos depósitos cenozóicos no Estado de São Paulo. IPT, São Paulo, Série Monografias, 9. 74p., 1983.

MILNE, G. Some suggested units for classification and mapping, particulary for East African soils. Soil Res., Berlim, V.4, p. 183-198, 1935.

MODENESI, M.C. Weathering and morphogenesis in a tropical plateau. Catena, 10:3, 237-251, 1983.

MURRAY, R.S. Estatítica. São Paulo, Shaum McGraw-Hill, 453p, 1985.

NORTON, L.D. \& HALL, G.F. Differentiation of lithologically similar soil parent materials. Soil. Sci. Soc. Am. J. Madison, 49 (2): 409-414, 1985.

OKA-FIORI, C. \& CRISTOFOLETTI, A. Mapeamento das formações superficiais da região de São Pedro-Piracicaba (SP,Brasil). Geociências, São Paulo, V 2:59-64, 1983.

OLIVEIRA, J.B. de; ALFONSI, R.R. \& PEDRO JUNIOR, M.J. Regimes hídricos e térmicos dos solos do Estado de São Paulo. In: Congresso bras. de Ci. do Solo, 15, Campinas, Sociedade Brasileira de Ciência do Solo, Anais. 359-362p., 1976.

OLIVEIRA, J.B., \& PRADO, H. Carta pedológica Semi-detalhada do Estado de São Paulo. Folha de Piracicaba, Campinas, Instituto Agronômico e Instituto Geográfico e Cartográfico. 1989 (escala 1:100.000).

ONSTAD, C.A.; PIERCE, F.J.; DOWDY, R.H. \& LARSON, W.E. Erosion and productivity interrelations on a soil landscape. Erosion and soil productivity, American Society of Agricultutral Engineers, 193-200, 1985

PENTEADO, M.N. Geomorfologia do setor centro ocidental da depressão periférica paulista. FFCL de Rio Claro, 1968. Universidade de São Paulo, Instituto de Geografia. São Paulo. Série Teses e Monografias, No. 22. 86p., 1976. (Tese de Doutoramento)

PENTEADO, M.N. Fundametos de geomorfologia. IBGE. Biblioteca Geográfica Brasileira, Série D. Publicação No. 3. Rio de Janeiro, 158p., 1974. 
PEREZ FILHO, A.; DONZELLI, J.B. \& LEPSCH, I.F. Relações solo geomorfologia em várzea do Rio Mogi-Guacu (SP). Rev. bras. Ci. Solo. 4;181-7, 1980.

PRADO, H. Desenvolvimento de horizontes superficiais de solos podzólicos relacionados com as formações Corumbataí e Pirambóia. 149p, 1986. (Tese de Mestrado)

QUEIROZ NETO, J.P. Observações preliminares sobre perfis de solos com bandas onduladas no Estado de São Paulo. São Paulo-USP, p. 34, (Sedimentologia e pedologia, 7), 1975.

QUEIROZ NETO, J.P. \& MODENESI, M.G. Observações preliminares sobre as relações entre solos e geomorfologia na área de Itu-Salto, São Paulo. Sedimentologia e Pedologia, 3 USP, Inst. Geografia, p28, 1973.

RAIJ, B. Van; QUAGGIO, J.A. ; CANTARELLA, H.; FERREIRA, M.E.; LOPES, A.S.; BATAGLIA, O.A. Análise química do solos pra fins de fertilidade. Campinas, Fundação Cargil, 165p., 1987.

RIZZO, L.T.B.; Relações solo-paisagem em uma área do extremo sul do estado de São Paulo (Bacia do Rio Ribeira de Iguape). Piracicaba, ESALQ-USP, 1991. (Dissertação Mestrado)

RODRIGUES,T. E. \& KLANT, E. Mineralogia e gênese de uma sequencia de solos do Distrito Federal. Rev. bras. Ci. Solo, Campinas, 2: 132-139, 1978.

RODRIGUES, R.R. Métodos fitossociológicos mais usados. In: Casa da agricultura, CATI, Campinas, no 1, p20-25. 1988.

RUHE, R.V. Elements of the Soil Landscape. Proceedings of the 7 th International Congress of soil science, Madison, Wisc. USA, Proc. V.23 p. 165-171, 1960.

SANS, L.M.A.; DEMATTÊ, J.L.I. \& CARVALHO, A. Características físicas, químicas e mineralógicas de três solos em uma catena sob cerrado e sobre calcário, em sete lagoas, MG. R. bras. Ci. Solo 3: 54-61, 1979.

SANTOS, S.M.; VIDAL-TORRADO, P.; SPAROVEK, G. \& DEMATTÊ, J.L.I. Caracterização do Podzólico Vermelho-Amarelo álico, Ta, desenvolvido do arenito Pirambóia. Anais do V congresso de iniciação científica da ESALQ/USP, Nov/90, Piracicaba, p.64, 1990. 
SCHWERTMANN, U.; KLANT, E.; KAMPF, N. \& SCHNEIDER, P. Observações pedogenéticas em solos do Brasil. Bol. Inf. da Soc. bras. Ci. Solo, Campinas, V.8 No2. p.39-43, 1983.

SIMONSON, R.W. Outline of a generalized theory of soil genesis Soil Soc. Amer. Proc. V.23:147-156, 1959.

SPAROVEK, G. \& VIDAL-TORRADO, P. Plano Diretor da microbacia do Córrego do Ceveiro, Volume I, ESALQ-USP, 285p, mimeo., 1991.

SPAROVEK, G.; De JONG Van LIER, Q. \& LEPSCH, I.F.; GMAP: Um programa de manipulação de mapas temáticos adaptados a computadores de pequeno porte. $\mathrm{O}$ exemplo do município de Piracicaba. Campinas Bol. Inf. da Soc. bras. Ci. Solo. 18(1):15-19, 1993.

SWANSON, D.K. Soils landform units for soil survey. Soil Survey Horizons, 31:1, 17-21, 1990.

TREMOCOLDI, W.A. \& STEINHARDT, G.C. Gênese de solos podzólicos derivados de arenitos da formação Bauru do Estado de São Paulo. R. bras. Ci. Solo, 11:59-65, 1987.

TRICART, J. As relações entre a morfogênese e a pedogênese. Notícia georfológica Campinas, 8(15):5-18, Jun. 1968.

UBERTI, A.A. \& KLANT, E. Relações solo-superfícies geomórficas na encosta inferior do nordeste do Rio Grande do Sul. R. bras. Ci. Solo, Campinas, 8:124-132. 1984.

VIDAL TORRADO, P. Relações solo $\mathrm{x}$ relevo em Mococa (SP); influência das características topográficas e posição na vertente nos atributos do solo. Escola Superior de Agricultura "Luis de Queiroz". Piracicaba, SP. 205p., 1989. (Dissertação de Mestrado)

VIDAL TORRADO, P. \& LEPSCH, I. F. Morfogênese dos solos de uma transeção com transição B latossólico - B textural sobre migmatitos em Mococa (SP). R. bras. Ci. Solo, Campinas, 17 (1):109-119. 1993.

VIDAL TORRADO, P. Morfogênese pedogênese no distrito de Tupi (Piracicaba-SP). Escola Superior de Agricultura "Luis de Queiroz". Piracicaba, SP. 208p., 1994. (Tese de Doutoramento) 
VIEIRA, L. S. Manual de ciência do solo com ênfase em solos tropicais. $2^{\mathrm{a}}$ ed. , Ed Agronômica Ceres, 1988,464p.

VREEKEN, W. J. Soils landscape chronograms for pedochronological analysis. Geoderma, 34:2, 149-164, 1984.

YOUNG, A. Slopes. Ed. Longman, London, 288p., 1972. 


\section{APÊNDICE 1}

ESTEREOGRAMA INCLUINDO A ÁREA ESTUDADA 


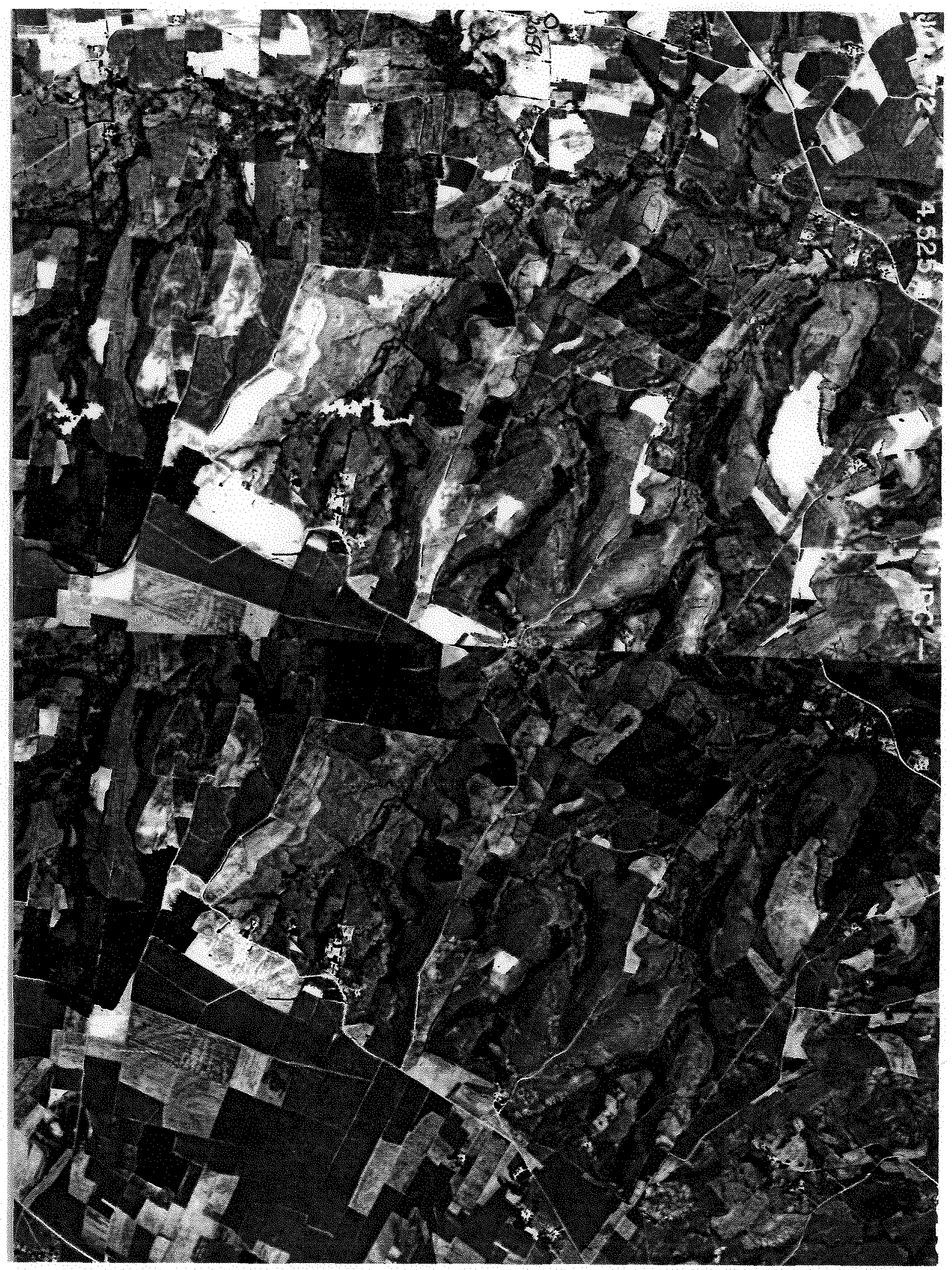


APÊNDICE 2

CÁLCULOS ESTATÍSTICOS DA DISTRIBUIÇÃO GRANULOMÉTRICA DA FRAÇÃO AREIA 


\section{TRANSEÇÃO 1}

$\begin{array}{lrrrr}\text { Amostra a } 100 \mathrm{~m} \text { do topo } & & \\ \text { intervalo phi } & \text { valor abs } & \% \text { rel } & \% \text { cum } \\ -1.00 \text { a } & 0.00 & 0.00 & 0 & 0 \\ 0.00 \text { a } & 1.00 & 2.00 & 3 & 3 \\ 1.00 \text { a } & 2.00 & 21.00 & 28 & 31 \\ 2.00 \text { a } & 3.00 & 39.00 & 53 & 84 \\ 3.00 \text { a } & 4.30 & 12.00 & 16 & 100\end{array}$

Interpretacao do grafico (segundo Folk e Ward, 1957) : media grafica 2.324 desvio padrao 0.713 moderadamente selecionado assimetria +0.019 aproximadamente simetrica curtose +1.106 mesocurtico

Amostra a 250m do topo

$\begin{array}{rrrrr}\text { intervalo phi } & \text { valor abs } & \% r e l & \% \text { cum } \\ -1.00 \mathrm{a} & 0.00 & 0.00 & 0 & 0 \\ 0.00 \mathrm{a} & 1.00 & 2.00 & 2 & 2 \\ 1.00 \mathrm{a} & 2.00 & 18.00 & 22 & 25 \\ 2.00 \mathrm{a} & 3.00 & 48.00 & 60 & 85 \\ 3.00 \mathrm{a} & 4.30 & 12.00 & 15 & 100\end{array}$

Interpretacao do grafico (segundo Folk e Ward, 1957) : media grafica 2.379 desvio padrao assimetria 0.653 moderadamente bem selecionado curtose +0.008 aproximadamente simetrica +1.205 leptocurtico

$\begin{array}{lrrrr}\text { Amostra a } 400 \mathrm{~m} \text { do topo } & & \\ \text { intervalo phi } & \text { valor abs } & \% \text { rel } & \% \text { cum } \\ -1.00 \text { a } & 0.00 & 0.00 & 0 & 0 \\ 0.00 \text { a } & 1.00 & 2.00 & 3 & 3 \\ 1.00 \text { a } & 2.00 & 23.00 & 29 & 32 \\ 2.00 \text { a } & 3.00 & 45.00 & 57 & 89 \\ 3.00 \text { a } & 4.30 & 9.00 & 11 & 100\end{array}$

Interpretacao do grafico (segundo Folk e Ward, 1957) : media grafica desvio padrao 2.256 assimetria 0.662 moderadamente bem selecionado curtose -0.002 aproximadamente simetrica +1.163 leptocurtico 


\begin{tabular}{|c|c|c|c|c|}
\hline \multicolumn{2}{|c|}{ intervalo phi } & valor abs & \%rel & $\%$ cum \\
\hline$-1.00 a$ & 0.00 & 0.00 & 0 & 0 \\
\hline $0.00 a$ & 1.00 & 1.00 & 1 & 1 \\
\hline $1.00 \mathrm{a}$ & 2.00 & 10.00 & 14 & 16 \\
\hline $2.00 a$ & 3.00 & 38.00 & 55 & 71 \\
\hline $3.00 a$ & 4.30 & 20.00 & 29 & 100 \\
\hline
\end{tabular}

Interpretacao do grafico (segundo Folk e Ward, 1957) : media grafica 2.656 desvio padrao 0.678 moderadamente bem selecionado assimetria +0.020 aproximadamente simetrica curtose +1.064 mesocurtico

Amostra a $700 \mathrm{~m}$ do topo

\begin{tabular}{rrrrr}
\multicolumn{1}{l}{ intervalo phi } & valor abs & $\%$ rel & $\%$ cum \\
-1.00 a & 0.00 & 0.00 & 0 & 0 \\
0.00 a & 1.00 & 1.00 & 1 & 1 \\
1.00 a & 2.00 & 11.00 & 15 & 16 \\
2.00 a & 3.00 & 40.00 & 55 & 71 \\
3.00 a & 4.30 & 21.00 & 29 & 100
\end{tabular}

Interpretacao do grafico (segundo Folk e Ward, 1957) : media grafica desvio padrao 2.656 assimetria 0.678 moderadamente bem selecionado curtose $+0.020$ aproximadamente simetrica +1.064 mesocurtico

Amostra a $850 m$ do topo

\begin{tabular}{rrrrr}
\multicolumn{1}{l}{ intervalo phi } & valor abs & $\%$ rel & $\%$ cum \\
-1.00 a & 0.00 & 0.00 & 0 & 0 \\
0.00 a & 1.00 & 1.00 & 1 & 1 \\
1.00 a & 2.00 & 14.00 & 19 & 20 \\
2.00 a & 3.00 & 40.00 & 54 & 74 \\
3.00 a & 4.30 & 19.00 & 26 & 100
\end{tabular}

Interpretacao do grafico (segundo Folk e Ward, 1957) : media grafica 2.578 desvio padrao 0.695 assimetria $\quad+0.034$ moderadamente bem selecionado curtose $+1.041$ aproximadamente simetrica mesocurtico 


\section{PERFIL 1}

$\begin{array}{lrrrr}\text { Ap } 0-5 \mathrm{~cm} & & & \\ \text { intervalo phi } & \text { valor abs } & \% \text { rel } & \% \text { cum } \\ -1.00 \text { a } & 0.00 & 0.00 & 0 & 0 \\ 0.00 \text { a } & 1.00 & 2.00 & 2 & 2 \\ 1.00 \text { a } & 2.00 & 25.00 & 28 & 30 \\ 2.00 \text { a } & 3.00 & 53.00 & 60 & 90 \\ 3.00 \text { a } & 4.30 & 9.00 & 10 & 100\end{array}$

Interpretacao do grafico (segundo Folk e Ward, 1957) : media grafica 2.274 desvio padrao assimetria

0.618 moderadamente bem selecionado curtose $+0.011$ aproximadamente simetrica +1.176 leptocurtico

$\begin{array}{lrrrr}\text { Bw3 } 57-150 \mathrm{~cm} & & & \\ \text { intervalo phi } & \text { valor abs } & \text { \%rel } & \% \text { cum } \\ -1.00 \text { a } & 0.00 & 0.00 & 0 & 0 \\ 0.00 \text { a } & 1.00 & 2.00 & 2 & 2 \\ 1.00 \text { a } & 2.00 & 20.00 & 24 & 27 \\ 2.00 \text { a } & 3.00 & 50.00 & 61 & 88 \\ 3.00 \text { a } & 4.30 & 10.00 & 12 & 100\end{array}$

Interpretacao do grafico (segundo Folk e Ward, 1957) : media grafica 2.325 desvio padrao 0.631 moderadamente bem selecionado assimetria +0.006 aproximadamente simetrica curtose +1.208 leptocurtico

Bw 200-250cm intervalo phi -1.00 a 0.00 0.00 a 1.00 valor abs \%rel \%cum

1.00 a 2.00 0.00 2.00 0

2.00 a 3.00 $20.00 \quad 25 \quad 27$ 3.00 a 4.30 $49.00 \quad 60 \quad 88$ $10.00 \quad 12 \quad 100$

Interpretacao do grafico (segundo Folk e Ward, 1957) : media grafica desvio padrao assimetria 2.325 0.631 moderadamente bem selecionado curtose +0.006 aproximadamente simetrica +1.208 leptocurtico 
Bw $300-350 \mathrm{~cm}$

$\begin{array}{rrrrr}\text { intervalo phi } & \text { valor abs } & \% r e l & \% \text { cum } \\ -1.00 \text { a } & 0.00 & 0.00 & 0 & 0 \\ 0.00 \text { a } & 1.00 & 2.00 & 3 & 3 \\ 1.00 \text { a } & 2.00 & 28.00 & 36 & 38 \\ 2.00 \text { a } & 3.00 & 41.00 & 53 & 91 \\ 3.00 \text { a } & 4.30 & 7.00 & 9 & 100\end{array}$

Interpretacao do grafico (segundo Folk e Ward, 1957) : media grafica desvio padrao assimetria 2.180 0.648 moderadamente bem selecionado curtose $+0.032$ +1.113 leptocurtico

Bw $400-450 \mathrm{~cm}$ intervalo phi -1.00 a 0.00

$\begin{array}{rrr}\text { valor abs } & \% \text { rel } & \% \text { cum } \\ 0.00 & 0 & 0 \\ 2.00 & 3 & 3 \\ 20.00 & 27 & 30 \\ 44.00 & 59 & 89 \\ 8.00 & 11 & 100\end{array}$

0.00 a 1.00

1.00 a 2.00

2.00 a 3.00

3.00 a 4.30

8.00 aproximadamente simetrica

Interpretacao do grafico (segundo Folk e Ward, 1957) : media grafica 2.273 desvio padrao 0.655 assimetria $-0.017$ moderadamente bem selecionado curtose $+1.196$ aproximadamente simetrica leptocurtico

Bw $500-550 \mathrm{~cm}$ intervalo phi -1.00 a 0.00 valor abs \%rel \%cum

0.00 a 1.00 0.00 00 1.00 a 2.00 2.00 a 3.00 $2.00 \quad 3 \quad 3$

3.00 a 4.30 $21.00 \quad 27 \quad 29$ $46.00 \quad 59 \quad 88$ $9.00 \quad 12 \quad 100$

Interpretacao do grafico (segundo Folk e Ward, 1957) : media grafica desvio padrao assimetria 2.294

0.663 moderadamente bem selecionado curtose -0.017 aproximadamente simetrica +1.204 leptocurtico

Continua 


\begin{tabular}{|c|c|c|c|c|}
\hline \multicolumn{5}{|c|}{$\mathrm{Bw} \quad 650-700 \mathrm{~cm}$} \\
\hline-1.00 & 0.00 & 0.00 & 0 & \\
\hline 0.00 & 1.00 & 2.00 & 3 & \\
\hline $1.00 \mathrm{a}$ & 2.00 & 17.00 & 23 & 26 \\
\hline 2.00 & 3.00 & 40.00 & 54 & 8 \\
\hline 3.00 & 4.30 & 15.00 & 20 & 100 \\
\hline
\end{tabular}

Interpretacao do grafico (segundo Folk e Ward, 1957) : media grafica 2.428

desvio padrao 0.735 moderadamente selecionado assimetria $\quad-0.000$ aproximadamente simetrica curtose +1.129 leptocurtico

Continua 


\section{TRANSEÇÃO 2}

$\begin{array}{lrrrr}\text { Amostra a } 50 m \text { do topo } & & \\ \text { intervalo phi } & \text { valor abs } & \% r e l & \% \text { cum } \\ -1.00 \text { a } 0.00 & 0.00 & 0 & 0 \\ 0.00 \text { a } & 1.00 & 1.00 & 1 & 1 \\ 1.00 \text { a } & 2.00 & 19.00 & 23 & 25 \\ 2.00 \text { a } & 3.00 & 45.00 & 56 & 80 \\ 3.00 \text { a } & 4.30 & 16.00 & 20 & 100\end{array}$

Interpretacao do grafico (segundo Folk e Ward, 1957) : media grafica 2.462 desvio padrao 0.679 moderadamente bem selecionado assimetria $+0.068$ curtose $+1.055$ aproximadamente simetrica mesocurtico

Amostra a 500m do topo

$\begin{array}{rrrrr}\text { intervalo phi } & \text { valor abs } & \% \text { rel } & \% \text { cum } \\ -1.00 \text { a } & 0.00 & 0.00 & 0 & 0 \\ 0.00 \text { a } & 1.00 & 0.00 & 0 & 0 \\ 1.00 \text { a } & 2.00 & 4.00 & 6 & 6 \\ 2.00 \text { a } & 3.00 & 37.00 & 55 & 61 \\ 3.00 \text { a } & 4.30 & 26.00 & 39 & 100\end{array}$

Interpretacao do grafico (segundo Folk e Ward, 1957) : media grafica 2.869

desvio padrao 0.588 moderadamente bem selecionado assimetria +0.042 aproximadamente simetrica curtose +1.055 mesocurtico

Amostra a 1000m do topo intervalo phi valor abs -1.00 a 0.00 0.00 \%rel \%cum 0.00 a 1.00 0.00 0

1.00 a 2.00 2.00 $0 \quad 0$

2.00 a 3.00 40.00 3.00 a 4.30 16.00

33

$69 \quad 72$

$28 \quad 100$

Interpretacao do grafico (segundo Folk e Ward, 1957) : media grafica 2.810 desvio padrao 0.494 bem selecionado assimetria +0.180 assimetria positiva (finos) curtose +1.203 leptocurtico 
Amostra a $1500 m$ do topo

$\begin{array}{rrrrr}\text { intervalo phi } & \text { valor abs } & \% r e l & \% \text { cum } \\ -1.00 \text { a } & 0.00 & 0.00 & 0 & 0 \\ 0.00 \text { a } & 1.00 & 0.00 & 0 & 0 \\ 1.00 \text { a } & 2.00 & 1.00 & 2 & 2 \\ 2.00 \text { a } & 3.00 & 21.00 & 50 & 52 \\ 3.00 \text { a } & 4.30 & 20.00 & 48 & 100\end{array}$

Interpretacao do grafico (segundo Folk e Ward, 1957) : media grafica 3.006

desvio padrao 0.519 moderadamente bem selecionado assimetria $\quad+0.088$ aproximadamente simetrica curtose +1.004 mesocurtico

Amostra a $2000 m$ do topo

$\begin{array}{rrrrr}\text { intervalo phi } & \text { valor abs } & \% \text { rel } & \% \text { cum } \\ -1.00 \text { a } & 0.00 & 0.00 & 0 & 0 \\ 0.00 \text { a } & 1.00 & 0.00 & 0 & 0 \\ 1.00 \text { a } & 2.00 & 4.00 & 6 & 6 \\ 2.00 \text { a } & 3.00 & 46.00 & 68 & 74 \\ 3.00 \mathrm{a} & 4.30 & 18.00 & 26 & 100\end{array}$

Interpretacao do grafico (segundo Folk e Ward, 1957) : media grafica 2.745 desvio padrao 0.541 moderadamente bem selecionado assimetria +0.119 assimetria positiva (finos) curtose $\quad+1.243$ leptocurtico

Amostra a 2600m do topo

$\begin{array}{rrrrr}\text { intervalo phi } & \text { valor abs } & \% r e l & \% \text { cum } \\ -1.00 \text { a } & 0.00 & 0.00 & 0 & 0 \\ 0.00 \mathrm{a} & 1.00 & 0.00 & 0 & 0 \\ 1.00 \mathrm{a} & 2.00 & 3.00 & 5 & 5 \\ 2.00 \mathrm{a} & 3.00 & 46.00 & 72 & 77 \\ 3.00 \mathrm{a} & 4.30 & 15.00 & 23 & 100\end{array}$

Interpretacao do grafico (segundo Folk e Ward, 1957) : media grafica 2.724

desvio padrao 0.498 bem selecionado

assimetria +0.158 assimetria positiva (finos)

curtose +1.262 leptocurtico

Continua 
PERFIL 2

\begin{tabular}{|c|c|c|c|c|}
\hline \multicolumn{5}{|c|}{ Ap $0-5 c m$} \\
\hline-1.00 & 0.00 & 0.00 & 0 & 0 \\
\hline 0.00 & 1.00 & 1.00 & 1. & \\
\hline 1.00 & 2.00 & 16.00 & 18 & 19 \\
\hline 2.00 & 3.00 & 46.00 & 52 & $7:$ \\
\hline 3.00 & 4.30 & 25.00 & 28 & 100 \\
\hline
\end{tabular}

Interpretacao do grafico (segundo Folk e Ward, 1957) : media grafica 2.609

desvio padrao 0.699 moderadamente bem selecionado

assimetria +0.022 aproximadamente simetrica

curtose +1.025 mesocurtico

E $5-22 \mathrm{~cm}$

intervalo phi

-1.00 a 0.00

valor abs \%rel \%cum

0.00 a 1.00

$0.00 \quad 0 \quad 0$

1.00 a 2.00

$1.00 \quad 1 \quad 1$

2.00 a 3.00

$14.00 \quad 15 \quad 16$

3.00 a 4.30

42.00

$45 \quad 61$

$37.00 \quad 39 \quad 100$

Interpretacao do grafico (segundo Folk e Ward, 1957) : media grafica 2.745

desvio padrao

0.720 moderadamente selecionado

assimetria

$-0.076$

aproximadamente simetrica

curtose

$+0.966$

mesocurtico

E2 $22-68 \mathrm{~cm}$

intervalo phi

-1.00 a 0.00

valor abs \%rel \%cum

0.00 a 1.00

0.00

1.00

0

1.00 a 2.00

14.00

1

$16 \quad 17$

2.00 a 3.00

44.00

$49 \quad 66$

3.00 a 4.30

31.00

$34 \quad 100$

Interpretacao do grafico (segundo Folk e Ward, 1957) : media grafica

2.688

desvio padrao 0.711

assimetria $\quad-0.024$

moderadamente selecionado

curtose

$+0.986$

aproximadamente simetrica mesocurtico

Continua 


\begin{tabular}{|c|c|c|c|c|}
\hline \multicolumn{2}{|c|}{ intervalo phi } & valor abs & \%rel & $\%$ cum \\
\hline-1.00 & 0.00 & 0.00 & 0 & 0 \\
\hline 0.00 & 1.00 & 1.00 & 1 & \\
\hline 1.00 & 2.00 & 11.00 & 15 & 16 \\
\hline 2.00 & 3.00 & 32.00 & 43 & 59 \\
\hline 3.00 & 4.30 & 30.00 & 41 & 100 \\
\hline
\end{tabular}

Interpretacao do grafico (segundo Folk e Ward, 1957) : media grafica 2.763

desvio padrao

0.727 moderadamente selecionado

assimetria

$-0.102$

assimetria negativa (grosseiros)

curtose

$+0.956$ mesocurtico

Bt1 $110-160 \mathrm{~cm}$ intervalo phi -1.00 a 0.00 valor abs \%rel \%cum 0.00 a 1.00 0.00

1.00 00

1.00 a 2.00

9.00 $1 \quad 1$

2.00 a 3.00 31.00

3.00 a 4.30

29.00

$13 \quad 14$

$44 \quad 59$

$41 \quad 100$

Interpretacao do grafico (segundo Folk e Ward, 1957) : media grafica 2.789

desvio padrao

0.706

moderadamente bem selecionado

assimetria

$-0.089$

$+0.989$

aproximadamente simetrica

curtose

mesocurtico

Bt2 $160+\mathrm{cm}$

intervalo phi

-1.00 a 0.00

valor abs \%rel \%cum

0.00 a 1.00

0.00

1.00

$0 \quad 0$

1.00 a 2.00

11.00

11

2.00 a 3.00

36.00

$14 \quad 16$

3.00 a 4.30

28.00

$47 \quad 63$

$37 \quad 100$

Interpretacao do grafico (segundo Folk e Ward, 1957) : media grafica 2.727

desvio padrao 0.713 moderadamente selecionado

assimetria $\quad-0.052$ aproximadamente simetrica

curtose +0.979 mesocurtico

Contiua 
PONTOS DA FORMAÇÃO CORUMBATAI

$\begin{array}{lrrrr}\text { AM } 16740-60 \mathrm{~cm} & & & \\ \text { intervalo phi } & \text { valor abs } & \% \text { rel } & \% \text { cum } \\ -1.00 \text { a } 0.00 & 1.00 & 12 & 12 \\ 0.00 \text { a } 1.00 & 0.00 & 0 & 12 \\ 1.00 \text { a } 2.00 & 1.00 & 12 & 25 \\ 2.00 \text { a } & 3.00 & 2.00 & 25 & 50 \\ 3.00 \text { a } & 4.30 & 4.00 & 50 & 100\end{array}$

Interpretacao do grafico (segundo Folk e Ward, 1957) : media grafica desvio padrao 2.639

1.204 pobremente selecionado assimetria -0.534 assimetria muito negativa (grosseiros) curtose +1.288 leptocurtico

$\begin{array}{lrrrr}\text { AM } 185 \text { 40-50cm } & & & \\ \text { intervalo phi } & \text { valor abs } & \% r e l & \% \text { cum } \\ -1.00 \text { a } & 0.00 & 4.00 & 15 & 15 \\ 0.00 \text { a } & 1.00 & 5.00 & 19 & 35 \\ 1.00 \text { a } & 2.00 & 3.00 & 12 & 46 \\ 2.00 \text { a } & 3.00 & 6.00 & 23 & 69 \\ 3.00 \text { a } & 4.30 & 8.00 & 31 & 100\end{array}$

Interpretacao do grafico (segundo Folk e Ward, 1957) : media grafica desvio padrao assimetria 1.863

1.472 pobremente selecionado curtose +0.684 platicurtico

AM $173 \quad 10-30 \mathrm{~cm}$ intervalo phi -1.00 a 0.00 valor abs \%rel \%cum 0.00 a 1.00 2.00 $8 \quad 8$

1.00 a 2.00 $4.00 \quad 16 \quad 24$

2.00 a 3.00

3.00 a 4.30

$4.00 \quad 16 \quad 40$

$11.00 \quad 44 \quad 84$

$\begin{array}{lll}4.00 & 16 \quad 100\end{array}$

Interpretacao do grafico (segundo Folk e Ward, 1957) : media grafica 1.930

desvio padrao 1.193 pobremente selecionado assimetria -0.302 assimetria muito negativa (grosseiros) curtose +0.955 mesocurtico 


$\begin{array}{lrrrr}\text { AM } 203 & 20-40 \mathrm{~cm} & & & \\ \text { intervalo phi } & \text { valor abs } & \% \text { rel } & \% \text { cum } \\ -1.00 \text { a } & 0.00 & 2.00 & 9 & 9 \\ 0.00 \text { a } & 1.00 & 2.00 & 9 & 17 \\ 1.00 \text { a } & 2.00 & 3.00 & 13 & 30 \\ 2.00 \text { a } & 3.00 & 8.00 & 35 & 65 \\ 3.00 \text { a } & 4.30 & 8.00 & 35 & 100\end{array}$

Interpretacao do grafico (segundo Folk e Ward, 1957) : media grafica desvio padrao assimetria 2.293 1.258 pobremente selecionado curtose
AM $22320-40 \mathrm{~cm}$
intervalo phi -1.00 a 0.00 valor abs \%rel \%cum 0.00 a 1.00 1.00 assimetria muito negativa (grosseiros) $-0.364$ $+1.103$ mesocurtico

1.00 a 2.00

1.00

$4 \quad 4$

2.00 a 3.00

2.00

$4 \quad 7$

3.00 a 4.30

13.00

$7 \quad 15$

$48 \quad 63$

(3.00 a 4.30

Interpretacao do grafico (segundo Folk e Ward, 1957) : media grafica desvio padrao assimetria 2.740

0.876 moderadamente selecionado curtose -0.202 assimetria negativa (grosseiros) +1.485 leptocurtico

Continua 
GERAL

$\begin{array}{lrrrr}\text { TRANSEÇÃO A } & & & \\ \text { intervalo phi } & \text { valor abs } & \% \text { rel } & \% \text { cum } \\ -1.00 \text { a } & 0.00 & 0.00 & 0 & 0 \\ 0.00 \text { a } & 1.00 & 2.00 & 2 & 2 \\ 1.00 \text { a } & 2.00 & 18.00 & 22 & 25 \\ 2.00 \text { a } & 3.00 & 48.00 & 60 & 85 \\ 3.00 \text { a } & 4.30 & 12.00 & 15 & 100\end{array}$

Interpretacao do grafico (segundo Folk e Ward, 1957) : media grafica 2.379

desvio padrao 0.653 moderadamente bem selecionado assimetria +0.008 aproximadamente simetrica curtose +1.205 leptocurtico

$\begin{array}{lrrrr}\text { TRANSEÇÃo B } & & & \\ \text { intervalo phi } & \text { valor abs } & \% \text { rel } & \% \text { cum } \\ -1.00 \text { a } & 0.00 & 0.00 & 0 & 0 \\ 0.00 \text { a } & 1.00 & 0.00 & 0 & 0 \\ 1.00 \text { a } & 2.00 & 2.00 & 3 & 3 \\ 2.00 \text { a } & 3.00 & 40.00 & 69 & 72 \\ 3.00 \text { a } & 4.30 & 16.00 & 28 & 100\end{array}$

Interpretacao do grafico (segundo Folk e Ward, 1957) : media grafica desvio padrao assimetria 2.810 curtose 0.494 bem selecionado +0.180 assimetria positiva (finos) +1.203 leptocurtico

TRADAGEM PROFUNDA

\begin{tabular}{rrrrr}
\multicolumn{2}{l}{ intervalo phi } & valor abs & $\%$ rel & \%cum \\
-1.00 a & 0.00 & 0.00 & 0 & 0 \\
0.00 a & 1.00 & 2.00 & 2 & 2 \\
1.00 a & 2.00 & 20.00 & 25 & 27 \\
2.00 a & 3.00 & 49.00 & 60 & 88 \\
3.00 a & 4.30 & 10.00 & 12 & 100
\end{tabular}

Interpretacao do grafico (segundo Folk e Ward, 1957) : media grafica 2.325 desvio padrao 0.631 moderadamente bem selecionado assimetria +0.006 aproximadamente simetrica curtose +1.208 leptocurtico 


\begin{tabular}{|c|c|c|c|c|}
\hline interva & o phi & valor abs & \%rel & \%cum \\
\hline-1.00 & 0.00 & 0.00 & 0 & \\
\hline 0.00 & 1.00 & 0.00 & 0 & \\
\hline 1.00 & 2.00 & 2.00 & 3 & \\
\hline 2.00 & 3.00 & 54.00 & 90 & 93 \\
\hline 3.00 & 4.30 & 4.00 & 7 & 100 \\
\hline
\end{tabular}

Interpretacao do grafico (segundo Folk e Ward, 1957) : media grafica 2.560

desvio padrao 0.328 muito bem selecionado

assimetria +0.087 aproximadamente simetrica

curtose +1.212 leptocurtico

PONTO CORUMBATAI

$\begin{array}{rrrrr}\text { intervalo phi } & \text { valor abs } & \% \text { rel } & \% \text { cum } \\ -1.00 \text { a } & 0.00 & 0.00 & 0 & 0 \\ 0.00 \text { a } & 1.00 & 2.00 & 10 & 10 \\ 1.00 \text { a } & 2.00 & 3.00 & 14 & 24 \\ 2.00 \text { a } & 3.00 & 8.00 & 38 & 62 \\ 3.00 \text { a } & 4.30 & 8.00 & 38 & 100\end{array}$

Interpretacao do grafico (segundo Folk e Ward, 1957) : media grafica 2.546

desvio padrao 0.972 moderadamente selecionado

assimetria -0.254 assimetria negativa (grosseiros)

curtose +1.091 mesocurtico 


\section{APENDICE 3}

DESCRIÇÕES MORFOLÓGICAS DE PERFIS 


\section{PERFIL 1}

CLASSIFICAÇÃO: Latossolo Vermelho-Amarelo, álico ou distrófico, A moderado textura média

LOCALIZAÇÃO: Bairro Campestre, próximo a Fazenda Dona Antonia

SITUAÇÃO: Topo

LITOLOGIA: Cobertura Neocenozóica, provavelmente de origem deposicional

RELEVO: Suave ondulado

EROSÃO: Laminar pouco acentuada

DRENAGEM INTERNA: Bem drenado

COBERTURA VEGETAL ATUAL: Cana-de-açúcar

\section{DESCRIÇÃO MORFOLÓGICA}

Ap 0-5 cm; cinzento-avermelhado (5 YR 5/2); textura franco-arenosa; estrutura com aspecto maciço poroso que se desfaz em blocos subangulares, pequeno, fraco; muito friável, solta, não plástico, não pegajoso; transição difusa. Poucas raízes, presença de carvão.

Ap1 5-25 cm; bruno-avermelhado (5 YR 4/3); textura franca; estrutura com aspecto maciço poroso que se desfaz em blocos subangulares, grande, fraco a médio; muito friável, ligeiramente duro, não plástico, não pegajoso; manição difusa. Poucas raízes, presença de carvão.

Bw1 25-42 cm; vermelho-amarelado (5 YR 4/6); textura franca; estrutura com aspecto maciço poroso que se desfaz em blocos subangulares, pequeno a médio, fraco; muito friável, ligeiramente duro, não plástico, não pegajoso; transição difusa. Poucas raízes, presença de carvão, pequena evidência de compactação.

Bw2 $42-57 \mathrm{~cm}$; bruno-avermelhado-escuro (5 YR 3/3); textura franca; estrutura com aspecto maciço poroso que se desfaz em blocos subangulares, pequeno a médio, fraco e prismas, pequenos, médios, fracos; muito friável, ligeiramente duro, não plástico, não pegajoso; transição difusa.

Bw3 57-150+ cm; bruno-avermelhado-escuro (5 YR 3/3); textura franca; estrutura com aspecto maciço poroso que se desfaz em blocos subangulares, pequeno a médio, fraco; muito friável, ligeiramente duro, não plástico, não pegajoso; transição difusa. 


\section{PERFIL 2}

CLASSIFICAÇÃO: Podzólico Vermelho-Amarelo, álico ou distrófico, Ta ou Tb, A moderado (A+E espesso), abrupto, textura arenosa/média

LOCALIZAÇÃO: Bairro Campestre, próximo a Fazenda Dona Antonia, dentro de um maciço de Eucalipto

SITUAÇÃO: Terço inicial da encosta

LITOLOGIA: Arenito da formação Pirambóia

RELEVO: Ondulado

EROSÃO: Laminar acentuada

DRENAGEM INTERNA: Moderadamente drenado

COBERTURA VEGETAL ATUAL: Maciço de Eucalipto

\section{DESCRIÇÃO MORFOLÓGICA}

Ap $\quad 0-5 \mathrm{~cm}$; cinzento-escuro (10 YR 4/1); textura arenosa; estrutura em grãos simples com aspecto maciço poroso; muito friável, solto, não plástico, não pegajoso; transição difusa. Muitas raízes de gramíneas.

E 5-22 cm; bruno-claro-acinzentado (10 YR 6/3); textura arenosa; estrutura em grãos simples com aspecto maciço poroso que se desfaz em blocos subangulares, grande, fraco; muito friável, solto, não plástico, não pegajoso; transição difusa.

E2 22-68 cm; bruno (7,5 YR 5/4); textura arenosa; estrutura com aspecto maciço poroso que se desfaz em blocos subangulares, pequeno a médio, fraco; muito friável, ligeiramente duro, não plástico, não pegajoso; transição difusa.

Btg 68-110 cm; mosqueado bruno-amarelado (10 YR 5/4) e vermelho-amarelado (5 YR 5/6); textura franca; blocos subangulares, médio, fraco e prismas, pequenos, médios, fracos; muito friável, duro a muito duro, ligeiramente plástico a plástico, ligeiramente pegajoso; evidência de cutãns de eluviação na porção inferior,transição difusa.

Bt 110-160+ cm; vermelho-amarelado (5 YR 5/7); textura franca; blocos subangulares, médio, fraco; muito friável, duro a muito duro, ligeiramente plástico a plástico, ligeiramente pegajoso; transição difusa. 


\section{PERFIL 3}

CLASSIFICAÇÃO: Podzólico Vermelho-Amarelo, álico ou distrófico, Ta ou Tb, A moderado, abrupto, textura arenosa/média

LOCALIZAÇÃO: Bairro Campestre, na Fazenda Dona Antonia, barranco de carreador.

SITUAÇÃO: Terço médio da encosta

LITOLOGIA: Arenito da formação Pirambóia

RELEVO: Ondulado

EROSÃO: Laminar acentuada

DRENAGEM INTERNA: Moderadamente drenado

COBERTURA VEGETAL ATUAL: Cana-de-açúcar

\section{DESCRIÇÃO MORFOLÓGICA}

Ap $0-45 \mathrm{~cm}$; bruno (10 YR 5/3); textura arenosa; estrutura em grãos simples com aspecto maciço poroso; muito friável, solto, não plástico, não pegajoso; transição difusa. Muitas raízes de gramíneas.

E $\quad 45-54 \mathrm{~cm}$; bruno-claro (7,5 YR 6/4); textura arenosa; estrutura em grãos simples com aspecto maciço poroso que se desfaz em blocos subangulares, grande, fraco; muito friável, solto, não plástico, não pegajoso; transição difusa.

Bt1 54-100 cm; bruno (7,5 YR 5/4); textura franca; blocos subangulares, pequeno a médio, moderado a forte; friável, ligeiramente plástico, ligeiramente pegajoso.

Bt2 100-190 cm; vermelho-amarelado (5 YR 4/6); textura franca argilosa; blocos subangulares, pequeno a médio, moderado a forte; friável, ligeiramente plástico, ligeiramente pegajoso, cerosidade fraca.

Bt3 190+ cm; vermelho-amarelado (5 YR 4/6); textura franca-argilosa; blocos subangulares, pequeno, moderado; friável, ligeiramente plástico a plástico, ligeiramente pegajoso. 


\section{PERFIL 4}

CLASSIFICAÇÃO: Litossolo, álico ou distrófico, Ta ou Tb, A moderado, textura argilosa

LOCALIZAÇÃO: Bairro Campestre, Fazenda Dona Antonia

SITUAÇÃO: Escarpa

LITOLOGIA: Siltito da formação Corumbataí

RELEVO: Forte ondulado

EROSÃO: Laminar acentuada e sulcos

DRENAGEM INTERNA: Mal drenado

COBERTURA VEGETAL ATUAL: Pasto

\section{DESCRIÇÃO MORFOLÓGICA}

A1 $\quad 0-5 \mathrm{~cm}$; bruno-avermelhado-escuro (5 YR 3/3); textura franco-argilosa; estrutura em grumos e terra solta, alguns blocos subangulares, pequenos, fracos; friável, solto, não plástico, não pegajoso; transição difusa. Muitas raízes de gramíneas.

A2 5-12 cm; bruno-avermelhado-escuro (2,5 YR 3/4); textura argilosa; blocos subangulares, pequenos a médios, fraco; friável, ligeiramente duro, plástico, pegajoso.

AC 12-20+ cm; textura argilosa, estrutura da rocha em forma de folhelho, plástico e pegajoso. 


\section{APÊNDICE 4}

ANÁLISES QUÍMICAS E DE GRANULOMETRIA DOS PONTOS ANALISADOS E DOS PERFIS DESCRITOS 


\begin{tabular}{|c|c|c|c|c|c|c|c|c|c|c|c|c|c|c|c|c|c|c|c|c|c|c|c|c|}
\hline Рто & $\begin{array}{l}\text { PROF } \\
(\mathrm{cm})\end{array}$ & Cor & $\begin{array}{c}\mathrm{pH} \\
\mathrm{H} 2 \mathrm{O}\end{array}$ & $\begin{array}{c}\text { MO } \\
\mathrm{g} / \mathrm{kg}\end{array}$ & $\begin{array}{c}\mathrm{P} \\
\mathrm{mg} / \\
\mathrm{kg}\end{array}$ & $\mathrm{Na}$ & $\mathrm{Ca}$ & $\mathrm{Mg}$ & $\begin{array}{l}\mathrm{mmo} \\
\mathrm{K}\end{array}$ & $\begin{array}{c}10 / \mathrm{k} \\
\mathrm{AI}\end{array}$ & $\mathrm{H}+\mathrm{Al}$ & $S B$ & СTC7 & v & $\begin{array}{r}\%- \\
m\end{array}$ & $M$ & G & $\begin{array}{c}\text { Are } \\
M \\
M\end{array}$ & $\begin{array}{l}\text { eia } \\
\text { F } \\
\text { F- }\end{array}$ & MF & Tot & sil & $\begin{array}{l}\text { Arg } \\
\text { Tot }\end{array}$ & $\begin{array}{c}\mathrm{AMF} / \\
\mathrm{AF}\end{array}$ \\
\hline \multirow[t]{2}{*}{1} & $0-20$ & $7.54 / 2$ & 6,0 & 11,0 & 7 & 2,2 & 16 & 2 & 0,4 & 0 & 15 & 21 & 36 & 58 & 0 & 0 & 1 & 36 & 41 & 12 & 90 & 2 & $B$ & 0,29 \\
\hline & $60-80$ & $53 / 4$ & 5,9 & 10,0 & 1 & 0,5 & 16 & 3 & 0,2 & 4 & .28 & 20 & 48 & 41 & 17 & 0 & 1 & 31 & 29 & 10 & 71 & 5 & 24 & 0,34 \\
\hline \multirow[t]{2}{*}{7} & $0-20$ & $7.5 \quad 4 / 2$ & 4,2 & 16,0 & 9 & 0,2 & 4 & 1 & 0,7 & 12 & 31 & 6 & 37 & 16 & 67 & 0 & 2 & 24 & 52 & 10 & 88 & 2 & 10 & 0,19 \\
\hline & $60-80$ & $54 / 6$ & 3,8 & 11,0 & 2 & 0,2 & 2 & 1 & 0,5 & 16 & 47 & 4 & 51 & 7 & 81 & 0 & 2 & 20 & 46 & 9 & 77 & 4 & 19 & 0,20 \\
\hline \multirow[t]{2}{*}{9} & 0.10 & $53 / 4$ & 5.0 & 14,0 & 6 & 0,2 & 8 & 2 & 0,4 & 4 & 22 & 11 & 33 & 33 & 27 & 0 & 1 & 20 & 52 & 15 & 88 & 2 & 10 & 0,29 \\
\hline & $60-80$ & $2.5 \quad 4 / 6$ & 4.5 & 9,0 & 1 & 0,2 & 7 & 1 & 0,2 & 8 & 25 & B & 33 & 25 & 49 & 0 & 1 & 15 & 41 & 17 & 74 & 4 & 22 & 0,41 \\
\hline \multirow[t]{2}{*}{19} & $0-20$ & $2.5 \quad 3 / 4$ & 4,6 & 14,0 & 22 & 0,2 & 9 & 2 & 0,5 & 6 & 25 & 12 & 37 & 32 & 34 & 0 & 1 & 14 & 51 & 18 & 84 & 4 & 12 & 0,35 \\
\hline & $30-60$ & $2.5 \quad 3 / 6$ & 4,8 & 11,0 & 1 & 0,2 & 12 & 1 & 0,2 & 10 & 34 & 13 & 47 & 28 & 43 & 0 & 1 & 12 & 40 & 17 & 70 & 4 & 26 & 0,43 \\
\hline \multirow[t]{2}{*}{21.} & $0-25$ & $54 / 4$ & 5,4 & 19,0 & 36 & 0,2 & 20 & 9 & 0,9 & 0 & 22 & 30 & 52 & 58 & 0 & 0 & 2 & 21 & 42 & 10 & 75 & 4 & 21 & 0,24 \\
\hline & $25-60$ & $2.53 / 4$ & 4,8 & 10,0 & 2 & 0,2 & 19 & 2 & 0,2 & 8 & 34 & 21 & 55 & 39 & 27 & 0 & 1 & 11 & 35 & 15 & 62 & 14 & 24 & 0,43 \\
\hline \multirow[t]{2}{*}{25} & $0-20$ & $7.5 \quad 4 / 2$ & 4,2 & 10,0 & 17 & 0,2 & 3 & 1 & 0,3 & 7 & 20 & 5 & 25 & 18 & 61 & 0 & 1 & 15 & 49 & 23 & 88 & 4 & B & 0,47 \\
\hline & $30-60$ & $2.54 / 6$ & 5,5 & 9,0 & 2 & 0,2 & 25 & 1 & 0,2 & 1 & 18 & 26 & 44 & 59 & 4 & 0 & 1 & 17 & 40 & 10 & 68 & 2 & 30 & 0,25 \\
\hline 26 & $0-10$ & $54 / 6$ & 4,5 & 12,0 & 20 & 0,3 & 11 & 6 & 0,7 & 12 & 38 & 18 & 56 & 32 & 40 & 0 & 1 & 18 & 41 & 16 & 76 & 4 & 20 & 0,39 \\
\hline & $60-80$ & $2.54 / 8$ & 4,3 & 10,0 & 1 & 0,2 & 6 & 1 & 0,3 & 27 & 72 & 8 & 80 & 9 & 78 & 0 & 1 & 15 & 39 & 12 & 67 & 6 & 27 & 0,31 \\
\hline 27 & $0-20$ & $2.54 / 6$ & 4,3 & 9,0 & 15 & 0,2 & 3 & 1 & 0,3 & 7 & 20 & 5 & 25 & 18 & 61 & 0 & 1 & 11 & 57 & 21 & 90 & 4 & 6 & 0,37 \\
\hline & $60-80$ & $2.54 / 6$ & 3,9 & 8,0 & 1 & 0,2 & 2 & 1 & 1,1 & 25 & 47 & 4 & 51 & 8 & 85 & 0 & 1 & 18 & 43 & 12 & 74 & 2 & 24 & 0,28 \\
\hline 28 & 0.20 & $54 / 4$ & 5,2 & 13,0 & 8 & 0,2 & 15 & 5 & 1,4 & 1 & 20 & 22 & 42 & 52 & 4 & 0 & 1 & 17 & 42 & 18 & 78 & 4 & 18 & 0,43 \\
\hline & $60-80$ & $2.54 / 8$ & 5,1 & 9,0 & 1 & 0,2 & 23 & 5 & 0,6 & 2 & 18 & 29 & 47 & 62 & 6 & 0 & 2 & 16 & 36 & 13 & 66 & 4 & 30 & 0,36 \\
\hline 31 & $80-120$ & $2.5 / 6$ & 5,1 & 9,0 & 1. & 0,2 & 19 & 3 & 0,2 & 2 & 18 & 22 & 40 & 55 & 8 & 0 & 1 & 15 & 38 & 16 & 70 & 4 & 26 & 0,42 \\
\hline 34 & $0-20$ & $54 / 2$ & 5,1 & 12,0 & 10 & 0,2 & 10 & I & 0,3 & 2 & 16 & 12 & 28 & 42 & 15 & 0 & 1 & 22 & 49 & 18 & 90 & 4 & 6 & 0,37 \\
\hline & $60-80$ & $2.54 / 6$ & 4,4 & 7,0 & 1 & 0,2 & 8 & 4 & 0,7 & 15 & 34 & 13 & 47 & 28 & 54 & 0 & 1 & 19 & 39 & 9 & 68 & 6 & 26 & 0,23 \\
\hline 37 & $0-20$ & $7.5 \quad 5 / 2$ & 5,1 & 12,0 & 6 & 0,2 & 6 & 2 & 0,5 & 3 & 15 & 9 & 24 & 37 & 26 & 0 & 1 & 24 & 48 & 17 & 90 & 2 & B & 0,35 \\
\hline & $60-80$ & $2.5 \quad 4 / 4$ & 4,3 & 11,0 & 1 & 0,2 & 6 & 2 & 0,3 & 18 & 42 & 9 & 51 & 17 & 68 & 0 & 1 & 11 & 41 & 16 & 69 & 7 & 24 & 0,39 \\
\hline 45 & $0-20$ & $54 / 4$ & 5,0 & 11,0 & 12 & 0,2 & 6 & 1 & 0,3 & 4 & 20 & 8 & 28 & 27 & 35 & 0 & 2 & 26 & 48 & 12 & 88 & 4 & 8 & 0,25 \\
\hline & $60-80$ & $2.5 \quad 3 / 4$ & 4,7 & 10,0 & 1 & 0,2 & 13 & 1 & 0,2 & 5 & 25 & 14 & 39 & 37 & 26 & 0 & 2 & 20 & 40 & 12 & 74 & 4 & 22 & 0,30 \\
\hline 48 & $0-20$ & $54 / 3$ & 4,5 & 14,0 & 22 & $0 ; 2$ & 9 & 1 & 0,6 & 6 & 31 & 11 & 42 & 26 & 36 & 0 & 3 & 28 & 45 & 10 & 86 & 2 & 12 & 0,22 \\
\hline & $60-80$ & $2.5 \quad 4 / 6$ & 4,2 & 9,0 & 2 & 0,2 & 2 & 1 & 0,2 & 15 & 34 & 3 & 37 & 9 & 82 & 0 & 2 & 21 & 42 & 11 & 76 & 4 & 20 & 0,26 \\
\hline 51 & $0-20$ & $7.5 \quad 3 / 4$ & 4,0 & 13,0 & 23 & 0,2 & 4 & 1 & 0,8 & 24 & 34 & 6 & 40 & 15 & 70 & 0 & 2 & 24 & 45 & 11 & 82 & 4 & 14 & 0,24 \\
\hline & $60-80$ & $54 / 6$ & 4,4 & 9,0 & 1 & 0,2 & 5 & 2 & 0,5 & 11 & 31 & 8 & 39 & 20 & 59 & 0 & 2 & 21 & 39 & 12 & 74 & 4 & 22 & 0,31 \\
\hline 52 & $0-20$ & $53 / 4$ & 4,1 & 16,0 & 18 & 0,2 & 7 & 3 & 0,4 & 12 & 38 & 11 & 49 & 22 & 53 & 0 & 3 & 18 & 43 & 16 & 80 & 4 & 16 & 0,37 \\
\hline & $60-80$ & $2.5 \quad 3 / 4$ & 4,0 & 11,0 & 1 & 0,2 & 2 & 1 & 0,4 & 16 & 38 & 4 & 42 & 9 & 82 & 0 & 2 & 16 & 37 & 16 & 71 & 5 & 24 & 0,43 \\
\hline 53 & $0-20$ & $54 / 4$ & 4,3 & 11,0 & 11 & 0,2 & 4 & 1 & 0,5 & 12 & 42 & 6 & 48 & 12 & 68 & 0 & 4 & 25 & 47 & 10 & 86 & 2 & 12 & 0,21 \\
\hline & $60-80$ & $2.54 / 6$ & 4,0 & 10,0 & 2 & 0,2 & 3 & 1 & 0,3 & 16 & 34 & 5 & 39 & 12 & 78 & 0 & 2 & 20 & 42 & 12 & 76 & 6 & 18 & 0,29 \\
\hline 57 & 0.30 & $7.54 / 6$ & 4,6 & 15,0 & 10 & 0,2 & 7 & 1 & 0,5 & 8 & 34 & 9 & 43 & 20 & 48 & 0 & 3 & 27 & 44 & B & 82 & 2 & 16 & 0,18 \\
\hline & $40-60$ & $54 / 4$ & 4,3 & 9,0 & 2 & 0,2 & 2 & 1 & 0,2 & 13 & 34 & 3 & 37 & 9 & 79 & 0 & 2 & 23 & 43 & 10 & 78 & 4 & 18 & 0,23 \\
\hline 59 & $0-20$ & $104 / 2$ & 4,6 & 9,0 & 7 & 0,2 & 3 & 1 & 0,2 & 2 & 18 & 4 & 22 & 20 & 31 & 0 & 3 & 30 & 47 & 10 & 90 & 2 & B & 0,21 \\
\hline & $60-80$ & $54 / 6$ & 4,4 & 8,0 & 2 & 0,2 & 2 & 1 & 0,2 & 14 & 42 & 3 & 45 & 7 & 80 & 3 & 5 & 6 & 21 & 41 & 76 & 4 & 20 & 1,95 \\
\hline 61 & $0-20$ & $104 / 3$ & 4,5 & 8,0 & 8 & 0,2 & 2 & 1 & 0,3 & 6 & 20 & 4 & 24 & 15 & 63 & 0 & 2 & 32 & 45 & 13 & 92 & 2 & 6 & 0,29 \\
\hline & $60-80$ & $7.5 \quad 4 / 4$ & 4,0 & 7,0 & 1 & 0,2 & 3 & 1 & 0,4 & 17 & 31 & 5 & 36 & 13 & 79 & 0 & 2 & 23 & 41 & 14 & 80 & 3 & 17 & 0,34 \\
\hline 62 & $0-30$ & $53 / 4$ & 4,8 & 14,0 & 17 & 0,2 & 4 & 1 & 0,4 & 6 & 28 & 6 & 34 & 17 & 52 & 1 & 3 & 29 & 45 & 10 & 88 & 2 & 10 & 0,22 \\
\hline & $60-90$ & $54 / 4$ & 4,2 & 9,0 & 2 & 0,2 & 2 & 1 & 0,3 & 14 & 34 & 4 & 38 & 9 & 80 & 1 & 3 & 28 & 41 & 9 & 82 & 2 & 16 & 0,22 \\
\hline 65 & 0.20 & $2.5 \quad 3 / 4$ & 4,4 & 11,0 & 3 & 0,2 & 9 & 2 & 0,8 & 5 & 31 & 12 & 43 & 28 & 29 & 0 & 2 & 12 & 38 & 26 & 78 & 6 & 16 & 0,68 \\
\hline & $60-80$ & $2.5 \quad 3 / 4$ & 4,4 & 10,0 & 1 & 0,2 & 16 & 4 & 0,9 & 6 & 34 & 21 & 55 & 38 & 22 & 0 & 1 & 7 & 34 & 23 & 65 & 5 & 30 & 0,68 \\
\hline 67 & $0-20$ & $2.5 \quad 3 / 4$ & 4,8 & 10,0 & 4 & 2,6 & 8 & 2 & 0,7 & 4 & 31 & 13 & 44 & 30 & 23 & 0 & 2 & 15 & 43 & 20 & 80 & 4 & 16 & 0,47 \\
\hline & $60-80$ & $2.5 \quad 3 / 6$ & 4,6 & 9,0 & 1 & 0,2 & 8 & $I$ & 0.2 & 12 & 34 & 9 & 43 & 22 & 56 & 0 & 1 & 11 & 38 & 22 & 72 & 2 & 26 & 0,58 \\
\hline 68 & $0-20$ & $104 / 2$ & 7,1 & 12,0 & 83 & 2,0 & 47 & 18 & 5.2 & 0 & 9 & 72 & 81 & 89 & o & 0 & 0 & 11 & 46 & 28 & 85 & 9 & 6 & 0,61 \\
\hline & $20-40$ & $2.54 / 6$ & 5,7 & 8,0 & 1 & 0,5 & 34 & 6 & 0,6 & 0 & 22 & 41 & 63 & 65 & 0 & 0 & 0 & 8 & 32 & 22 & 62 & e & 30 & 0,69 \\
\hline 70 & $0-40$ & $104 / 3$ & 5,5 & 7,0 & 1 & 0,2 & 11 & 2 & 1,1 & 0 & 12 & 14 & 26 & 54 & 0 & 0 & 1 & 9 & 53 & 25 & 88 & 4 & B & 0,47 \\
\hline & $60-80$ & $7.5 \quad 5 / 6$ & 5,6 & 21,0 & 1 & 0,4 & 44 & 6 & 0,8 & 0 & 18 & 51 & 69 & 74 & 0 & 0 & 1 & 6 & 38 & 22 & 67 & 6 & 27 & 0,58 \\
\hline 74 & $0-20$ & $104 / 2$ & 5,7 & 12,0 & 2 & 0,4 & 16 & 3 & 0,5 & $a$ & 15 & 20 & 35 & 57 & 0 & 0 & 1 & 21 & 46 & 20 & 88 & 2 & 10 & 0,43 \\
\hline & $100-110$ & $104 / 6$ & 4,9 & 8,0 & 1 & 0,4 & 12 & 2 & 0,4 & 17 & 38 & 15 & 53 & 28 & 53 & $\mathrm{I}$ & 1 & 18 & 40 & 26 & 86 & 2 & 12 & 0,65 \\
\hline 76 & $0-20$ & $105 / 2$ & 5,5 & 12,0 & 2 & 0,2 & 11 & 2 & 0,5 & 0 & 16 & 14 & 30 & 46 & 0 & 0 & 0 & 20 & 47 & 21 & 88 & a & 4 & 0,45 \\
\hline & $70-100$ & $105 / 8$ & 4,4 & 9,0 & 1 & 0,2 & 2 & 1 & 0,2 & 32 & 72 & 3 & 75 & 5 & 90 & 0 & 0 & 17 & 33 & 20 & 70 & 4 & 26 & 0,61 \\
\hline 78 & $0-20$ & $105 / 8$ & 4,5 & 9,0 & 1 & 0,2 & 10 & 3 & 0,4 & 43 & 98 & 14 & 112 & 12 & 76 & 0 & 0 & 12 & 35 & 24 & 71 & 9 & 20 & 0,69 \\
\hline & $60-80$ & $105 / 2$ & 4,8 & 9,0 & 1 & 0,2 & 9 & 2 & 0,6 & 8 & 20 & 12 & 32 & 37 & 40 & 0 & 0 & 26 & 41 & 19 & 86 & 4 & 10 & 0,46 \\
\hline 80 & $0-20$ & $2.53 / 6$ & 4,9 & 11,0 & 2 & 0,7 & 37 & 13 & 2,1 & 68 & 228 & 53 & 281 & 19 & 56 & 0 & 0 & 5 & 23 & 17 & 45 & 16 & 39 & 0,74 \\
\hline & $40-60$ & $2.54 / 4$ & 5,4 & 7,0 & 3 & 4,4 & 29 & 17 & 2,8 & 102 & 429 & 53 & 482 & 11 & 66 & 0 & 0 & 1 & 5 & 8 & 14 & 31 & 55 & 1,60 \\
\hline 82 & $0-20$ & $51 / 3$ & 5,5 & 14,0 & 2 & 0,7 & 62 & 22 & 2,2 & 2 & 22 & 87 & 109 & 80 & 2 & 0 & 1 & 5 & 43 & 32 & 81 & 7 & 12 & 0,74 \\
\hline & $20-40$ & $2.5 \quad 4 / 4$ & 5,5 & 9,0 & 2 & 2,2 & 39 & 20 & 2,2 & 70 & 253 & 63 & 316 & 20 & 52 & o & 1 & 4 & 23 & 38 & 66 & 15 & 19 & 1,65 \\
\hline 83 & $0-20$ & $103 / 3$ & 5,4 & 16,0 & 3 & 0.4 & 16 & 2 & 0,5 & 0 & 18 & 19 & 37 & 51 & 0 & 0 & 0 & 25 & 43 & 24 & 92 & 2 & 6 & 0,56 \\
\hline & $70-90$ & $105 / 4$ & 3,8 & 10,0 & 1 & 0.2 & 1 & 1 & 0,8 & 32 & 109 & 3 & 112 & 3 & 91 & 0 & 0 & 24 & 36 & 11 & 71 & 4 & 25 & 0,31 \\
\hline
\end{tabular}

\section{Continua}


Areia

PTO PROF $\quad$ PH $\quad$ MO $P$ P

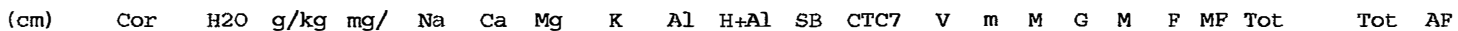

\begin{tabular}{|c|c|c|c|c|c|c|c|c|c|c|c|c|c|c|c|c|c|c|c|c|c|c|c|c|}
\hline \multirow[t]{2}{*}{84} & $0-20$ & $7.5 \quad 5 / 4$ & 7,3 & 27,0 & 27 & 0,6 & 85 & 7 & 1,8 & 0 & 9 & 94 & 103 & 91 & 0 & 0 & 0 & 19 & 38 & 16 & 73 & & 19 & 0,42 \\
\hline & $60-80$ & $2.5 \quad 3 / 4$ & 4.0 & 12,0 & 3 & 0,2 & 10 & $I$ & 0,5 & 20 & 64 & 12 & 76 & 15 & 63 & o & 0 & 19 & 34 & 19 & 72 & 5 & 23 & 0,56 \\
\hline \multirow[t]{2}{*}{87} & $0-20$ & $104 / 3$ & 4,5 & 14,0 & 9 & 0,2 & 15 & 3 & 1,5 & 8 & 31 & 20 & 51 & 39 & 29 & 0 & 1 & 11 & 62 & 7 & 81 & 0 & 19 & 0,11 \\
\hline & $40-60$ & $105 / 6$ & 5,2 & 11,0 & 1 & 0,5 & 37 & 4 & 0,8 & 2 & 15 & 42 & 57 & 74 & 5 & 0 & 1 & 5 & 42 & 19 & 67 & 9 & 24 & 0,45 \\
\hline \multirow[t]{2}{*}{90} & $0-20$ & $7.5 \quad 5 / 6$ & 4,5 & 8,0 & 1 & 0,2 & 7 & 4 & 1,0 & 10 & 18 & 12 & 30 & 40 & 45 & 0 & 1 & 7 & 60 & 17 & 85 & 2 & 13 & 0,28 \\
\hline & $40-70$ & $2.5 \quad 5 / 8$ & 4,0 & 10,0 & 1 & 0,2 & 11 & 5 & 0,7 & 37 & 109 & 17 & 126 & 13 & 69 & 2 & 2 & 8 & 42 & 16 & 70 & 2 & 28 & 0,38 \\
\hline \multirow[t]{2}{*}{91} & $0-10$ & $54 / 4$ & 4,8 & 12,0 & 2 & 0,7 & 36 & 10 & 1,8 & 12 & 28 & 49 & 77 & 63 & 20 & 0 & 1 & 2 & 36 & 17 & 56 & 24 & 20 & 0,47 \\
\hline & $60-80$ & $2.54 / 6$ & 4,1 & 7,0 & 2 & 0,9 & 19 & 8 & 1,8 & 60 & 313 & 30 & 343 & 9 & 67 & 1 & 1 & 2 & 40 & 15 & 59 & 24 & 17 & 0,38 \\
\hline 93 & $0-20$ & $104 / 3$ & 4,9 & 17,0 & 16 & 0,3 & 8 & 3 & 2,9 & 2 & 25 & 14 & 39 & 36 & 12 & 0 & 0 & 3 & 50 & 26 & 79 & 8 & 13 & 0,52 \\
\hline \multirow[t]{2}{*}{105} & $0-20$ & $104 / 3$ & 4,0 & 10,0 & 9 & 0,2 & 12 & 1 & 1,5 & 14 & 42 & 15 & 57 & 26 & 49 & 0 & 0 & 5 & 43 & 33 & 81 & 10 & 9 & 0,77 \\
\hline & $60-80$ & $55 / 6$ & 4,1 & 9,0 & 2 & 0,2 & 30 & 6 & 1,9 & 50 & 166 & 38 & 204 & 19 & 57 & 0 & 1 & 4 & 29 & 26 & 60 & 19 & 21 & 0,90 \\
\hline \multirow[t]{2}{*}{107} & $0-20$ & $105 / 2$ & 4,9 & 13,0 & 21 & 0.2 & 12 & 4 & 0,8 & 3 & 15 & 17 & 32 & 53 & 15 & 1 & 1 & 12 & 54 & 15 & 83 & 8 & 9 & 0,28 \\
\hline & $60-80$ & $7.5 \quad 5 / 6$ & 4,2 & 9,0 & 2 & 0,2 & 15 & 5 & 0,5 & 29 & 64 & 21 & 85 & 24 & 58 & 2 & 2 & 9 & 35 & 14 & 62 & 8 & 30 & 0,40 \\
\hline \multirow[t]{2}{*}{110} & $0-20$ & $105 / 4$ & 6,0 & 7,0 & 4 & 0,2 & 9 & 5 & 0,6 & 0 & 10 & 15 & 25 & 60 & o & 0 & 0 & 12 & 66 & 13 & 91 & 0 & 9 & 0,20 \\
\hline & $60-80$ & $104 / 3$ & 4,8 & 11,0 & 6 & 0.2 & 17 & 3 & 1,3 & 3 & 20 & 22 & 42 & 52 & 12 & 0 & 1 & 9 & 59 & 12 & 81 & 6 & 13 & 0,20 \\
\hline 111 & $0-20$ & $104 / 2$ & 3,9 & 15,0 & 20 & 0,2 & 12 & 4 & 1,8 & 18 & 98 & 18 & 116 & 16 & 50 & 0 & 1 & 4 & 52 & 17 & 74 & 11 & 15 & 0,33 \\
\hline & $80-100$ & $104 / 3$ & 4.8 & 19,0 & 10 & 0,2 & 34 & 4 & 1,2 & 4 & 28 & 39 & 67 & 58 & 9 & 1 & 1 & 4 & 46 & 17 & 69 & 12 & 19 & 0,37 \\
\hline 112 & $0-20$ & $103 / 2$ & 5,4 & 16,0 & 43 & 0,2 & 36 & 6 & 3,4 & 0 & 28 & 46 & 74 & 62 & 0 & 0 & 1 & 5 & 57 & 13 & 76 & 12 & 12 & 0,23 \\
\hline & $60-80$ & $105 / 6$ & 4,1 & 9,0 & 2 & 0,8 & 34 & 12 & 1,5 & 31 & 80 & 48 & 128 & 38 & 39 & 0 & o & 3 & 44 & 12 & 59 & 10 & 31 & 0,27 \\
\hline 114 & $0-20$ & $7.53 / 2$ & 5,9 & 31,0 & 18 & 0,3 & 27 & 12 & 4,3 & 0 & 18 & 44 & 62 & 71 & 0 & 0 & 1 & 12 & 57 & 12 & 82 & 8 & 10 & 0,21 \\
\hline & $60-80$ & $55 / 6$ & 4,4 & 10,0 & 2 & 0,3 & 23 & 10 & 1,2 & 20 & 52 & 35 & 87 & 40 & 37 & 0 & 1 & 7 & 41 & 18 & 67 & 8 & 25 & 0,44 \\
\hline 115 & $0-20$ & $103 / 3$ & 5,5 & 27,0 & 12 & 0,7 & 35 & 16 & 2,5 & 0 & 25 & 54 & 79 & 68 & 0 & 0 & 1 & 7 & 54 & 13 & 75 & 9 & 16 & 0,24 \\
\hline & $60-80$ & $105 / 8$ & 5,4 & 11,0 & 3 & 1,3 & 70 & 55 & 6,2 & 4 & 25 & 133 & 158 & 84 & 3 & 0 & 0 & 1 & 11 & 24 & 36 & 38 & 26 & 2,18 \\
\hline 119 & $0-25$ & $103 / 2$ & 5,3 & 37,0 & 11 & 0,4 & 60 & 25 & 6,2 & 2 & 34 & 92 & 126 & 73 & 2 & 1 & 1 & 5 & 31 & 19 & 57 & 22 & 21 & 0,61 \\
\hline & $60-70$ & $105 / 6$ & 4,5 & 13,0 & 3 & 0,6 & 31 & 23 & 2,6 & 42 & 150 & 57 & 207 & 28 & 42 & 1 & 4 & 4 & 11 & 11 & 31 & 35 & 34 & 1,00 \\
\hline 130 & $0-20$ & $53 / 4$ & 4,3 & 17,0 & 17 & 2,4 & 90 & 25 & 5,2 & 90 & 386 & 123 & 509 & 24 & 42 & 0 & 1 & 1 & 2 & 2 & 6 & 28 & 66 & 1,00 \\
\hline & $60-80$ & & 4,2 & 10,0 & 5 & 2,3 & 23 & 6 & 3,9 & 84 & 386 & 35 & 421 & 8 & 70 & 1 & 2 & 9 & 36 & 13 & 61 & 12 & 27 & 0,36 \\
\hline 131 & $0-20$ & $105 / 4$ & 5,1 & 8,0 & 3 & 0,3 & 6 & 2 & 0,6 & 2 & 10 & 9 & 19 & 47 & 18 & 0 & 1 & 21 & 69 & 6 & 97 & 1 & 2 & 0,09 \\
\hline & $60-80$ & $7.5 \quad 3 / 4$ & 5,3 & 22,0 & 9 & 0,6 & 23 & 7 & 2,2 & 1 & 20 & 33 & 53 & 62 & 3 & 0 & 0 & 5 & 66 & 17 & 88 & 6 & 6 & 0,26 \\
\hline 134 & $0-20$ & $7.5 \quad 3 / 2$ & 5,1 & 37,0 & 44 & 0,3 & 36 & 12 & 6,2 & 4 & 34 & 55 & 89 & 62 & 7 & 0 & 0 & 8 & 62 & 14 & 84 & 8 & 8 & 0,23 \\
\hline & $50-80$ & $10 \quad 4 / 4$ & 5,5 & 10,0 & 3 & 0,4 & 63 & 6 & 1,4 & 0 & 20 & 71 & 91 & 78 & 0 & 0 & 1 & 10 & 47 & 11 & 69 & 6 & 25 & 0,23 \\
\hline 140 & $0-20$ & $104 / 3$ & 5,9 & 12,0 & 2 & 0,2 & 6 & 3 & 0,5 & 0 & 12 & 10 & 22 & 45 & 0 & 0 & 1 & 23 & 49 & 10 & 83 & 8 & 9 & 0,20 \\
\hline & $60-80$ & $7.54 / 6$ & 4,7 & 9.0 & 1 & 0.5 & 20 & 8 & 0,6 & 12 & 28 & 29 & 57 & 51 & 29 & 0 & 1 & 10 & 43 & 15 & 69 & 9 & 22 & 0,35 \\
\hline 142 & $0-20$ & $54 / 3$ & 6,3 & 24,0 & 31 & 1,8 & 76 & 23 & 1,8 & 0 & 15 & 103 & 118 & 87 & 0 & 2 & 6 & 23 & 41 & 8 & 80 & 8 & 12 & 0,20 \\
\hline & $60-80$ & $7.5 \quad 5 / 4$ & 4,7 & 9,0 & 3 & 0,3 & 11 & 5 & 0,8 & 4 & 16 & 17 & 33 & 52 & 19 & 0 & 1 & 8 & 65 & 18 & 92 & 2 & 6 & 0,28 \\
\hline 147 & $0-20$ & $7.5 \quad 4 / 2$ & 6.6 & 19,0 & 141 & 0,5 & 55 & 9 & 6,2 & 0 & 13 & 71 & 84 & 84 & 0 & 1 & 1 & 7 & 62 & 11 & 82 & $B$ & 10 & 0,18 \\
\hline & $60-80$ & $7.5 \quad 5 / 4$ & 6,3 & 7,0 & 48 & 0,2 & 14 & 2 & 1,8 & 0 & 10 & 18 & 28 & 64 & o & 0 & 0 & 7 & 59 & 18 & 84 & 14 & 2 & 0,31 \\
\hline 151 & $0-30$ & $10 \quad 4 / 4$ & 5,2 & 29,0 & 20 & 0,4 & 26 & 10 & 3,6 & 4 & 31 & 40 & 71 & 56 & 9 & 0 & 1 & 8 & 51 & 15 & 75 & 7 & 18 & 0,29 \\
\hline & $60-80$ & $7.55 / 6$ & 3,9 & 9,0 & 2 & 0,4 & 13 & 4 & 1,2 & 36 & 58 & 19 & 77 & 24 & 66 & 0 & 1 & 6 & 45 & 19 & 71 & 5 & 24 & 0,42 \\
\hline 156 & $0-20$ & $7.5 \quad 3 / 2$ & 5,4 & 32,0 & 11 & 0,2 & 46 & 11 & 2,3 & 1 & 31 & 60 & 91 & 66 & 2 & 1 & 1 & 4 & 38 & 12 & 56 & 21 & 23 & 0,32 \\
\hline & $50-70$ & $104 / 4$ & 5,4 & 17,0 & 5 & 0,2 & 32 & 6 & 1,9 & 1 & 22 & 40 & 62 & 65 & 2 & 2 & 1 & 4 & 37 & 10 & 54 & 23 & 23 & 0,27 \\
\hline 159 & $0-30$ & $103 / 3$ & 4,9 & 23,0 & 13 & 0,2 & 23 & 3 & 2,5 & 6 & 34 & 29 & 63 & 46 & 17 & 0 & 0 & 3 & 74 & 11 & 88 & 4 & 8 & 0,15 \\
\hline 162 & $0-30$ & $106 / 3$ & 4,3 & 15,0 & 8 & 0,2 & 10 & 3 & 1,3 & 9 & 28 & 15 & 43 & 34 & 38 & 0 & 0 & 3 & 54 & 15 & 72 & 16 & 12 & 0,28 \\
\hline & $80-100$ & $104 / 2$ & 5,2 & 19,0 & 7 & 0,3 & 27 & 6 & 1,2 & 4 & 34 & 35 & 69 & 50 & 10 & 1 & 1 & 4 & 56 & 12 & 74 & 16 & 10 & 0,21 \\
\hline 166 & $0-10$ & $53 / 3$ & 5,8 & 71,0 & 105 & 1,0 & 80 & 35 & 11,4 & 0 & 34 & 127 & 161 & 79 & 0 & 1 & 1 & 1 & 2 & 1 & 6 & 45 & 49 & 0,50 \\
\hline & $10-30$ & $2.53 / 2$ & 5,6 & 52,0 & 53 & 1,3 & 90 & 55 & 6,9 & 0 & 38 & 153 & 191 & 80 & o & 1 & 1 & 0 & 0 & 0 & 2 & 34 & 64 & 0,00 \\
\hline 167 & $0-20$ & $103 / 2$ & 5,6 & 49,0 & 78 & 0,9 & 71 & 30 & 4,2 & 1 & 31 & 106 & 137 & 77 & 1 & 2 & 1 & 1 & 6 & 4 & 14 & 38 & 48 & 0,67 \\
\hline & $40-60$ & $104 / 2$ & 6,1 & 20,0 & 15 & 2,9 & 134 & 45 & 4,1 & 0 & 28 & 186 & 214 & 87 & 0 & 1 & 0 & 1 & 2 & 4 & e & 17 & 75 & 2,00 \\
\hline 169 & $0-20$ & $7.5 \quad 3 / 2$ & 5,7 & 54,0 & 110 & 0,9 & 122 & 25 & 4,5 & o & 38 & 152 & 190 & 80 & 0 & 6 & 6 & 3 & 3 & 2 & 20 & 38 & 42 & 0,67 \\
\hline 170 & $0-20$ & $104 / 3$ & 5,5 & 33,0 & 32 & 1,3 & 53 & 8 & 1,6 & 0 & 31 & 64 & 95 & 67 & 0 & 1 & 1 & 2 & 42 & 9 & 55 & 21 & 24 & 0,21 \\
\hline & $60-80$ & $103 / 3$ & 5,5 & 23,0 & 32 & 2,1 & 55 & 17 & 2,0 & 0 & 34 & 76 & 110 & 69 & 0 & 3 & 3 & 5 & 15 & 4 & 30 & 34 & 36 & 0,27 \\
\hline 172 & $0-20$ & $103 / 2$ & 5,2 & 25,0 & 8 & 0.7 & 30 & 8 & 3,1 & 2 & 42 & 42 & 84 & 50 & 5 & 1 & 2 & 4 & 23 & 9 & 39 & 29 & 32 & 0,39 \\
\hline & $40-60$ & $7.5 \quad 4 / 2$ & 4,2 & 14,0 & 8 & 5,3 & 33 & 22 & 4,8 & 102 & 429 & 65 & 494 & 13 & 61 & 1 & 1 & 1 & 4 & 2 & 9 & 17 & 74 & 0,50 \\
\hline 173 & $0-20$ & $10 \quad 3 / 2$ & 9,2 & 18,0 & 30 & 95,0 & 83 & 25 & 3,3 & 2 & 6 & 206 & 212 & 97 & 1 & 1 & 1 & 2 & 20 & 11 & 35 & 30 & 35 & 0,55 \\
\hline & $20-40$ & $104 / 2$ & 8,5 & 10,0 & 11 & 84,0 & 104 & 55 & 2,2 & 2 & B & 245 & 253 & 97 & 1 & 0 & 0 & 0 & 22 & 8 & 30 & 27 & 43 & 0,36 \\
\hline 174 & $0-30$ & $53 / 3$ & 5,6 & 35,0 & 22 & 3,0 & 145 & 25 & 3,3 & 0 & 34 & 176 & 210 & 84 & 0 & 3 & 3 & 2 & 4 & 1 & 13 & 43 & 44 & 0,25 \\
\hline 178 & $0-20$ & $105 / 2$ & 4,4 & 20,0 & 5 & 2,0 & 24 & 9 & 4,2 & 14 & 58 & 39 & 97 & 40 & 26 & 0 & 1 & 2 & 21 & 9 & 33 & 32 & 35 & 0,43 \\
\hline & $50-70$ & $104 / 2$ & 4,8 & 15,0 & 5 & 14,0 & 48 & 32 & 4,2 & 35 & 98 & 98 & 196 & 50 & 26 & 0 & 1 & 2 & 9 & 3 & 15 & 31 & 54 & 0,33 \\
\hline 181 & $0-20$ & $103 / 3$ & 4,7 & 21,0 & 13 & 6,2 & 64 & 31 & 4,6 & 17 & 72 & 106 & 178 & 60 & 14 & 0 & 0 & 1 & 8 & 6 & 15 & 30 & 55 & 0,75 \\
\hline & $30-50$ & $104 / 2$ & 6,6 & 10,0 & 12 & 19,5 & 79 & 71 & 2,8 & 0 & 18 & 172 & 190 & 91 & 0 & 0 & 0 & 0 & 7 & 8 & 15 & 33 & 52 & 1,14 \\
\hline
\end{tabular}

\section{Continua}




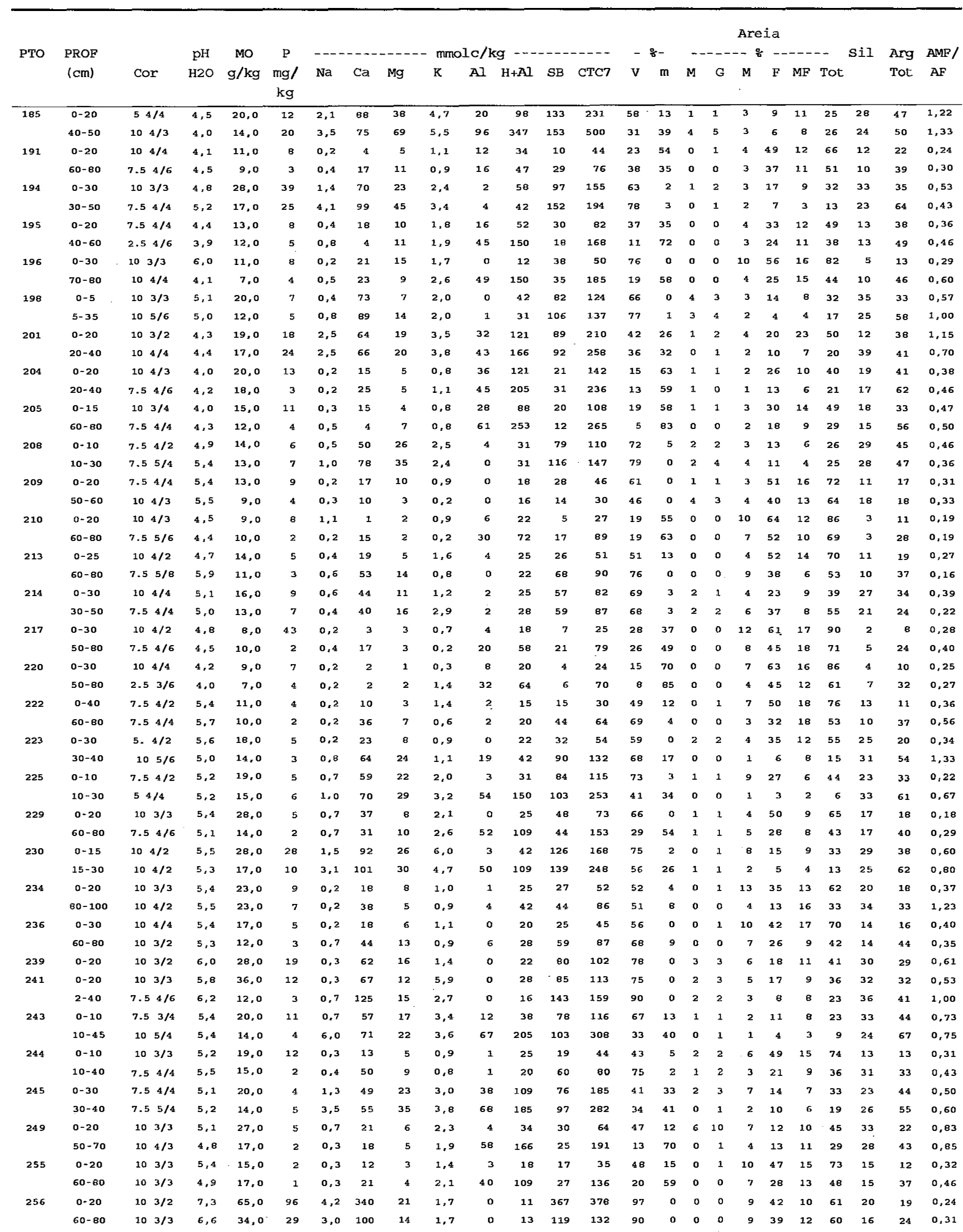

\section{Continua}




\begin{tabular}{|c|c|c|c|c|c|c|c|c|c|c|c|c|c|c|c|c|c|c|c|c|c|c|c|c|}
\hline \multirow{3}{*}{ Рто } & \multirow{3}{*}{$\begin{array}{l}\text { PROF } \\
(\mathrm{cm})\end{array}$} & \multirow[b]{3}{*}{ Cor } & \multirow{3}{*}{$\begin{array}{c}\mathrm{pH} \\
\mathrm{H} 2 \mathrm{O}\end{array}$} & \multirow{3}{*}{$\begin{array}{c}\text { MO } \\
\mathrm{g} / \mathrm{kg}\end{array}$} & \multirow{3}{*}{$\begin{array}{c}\mathrm{P} \\
\mathrm{mg} / \\
\mathrm{kg}\end{array}$} & \multirow{3}{*}{$\mathrm{Na}$} & \multirow[b]{3}{*}{$\mathrm{Ca}$} & \multirow{3}{*}{$\mathrm{Mg}$} & & & & & & & & & & re & & & & & & \\
\hline & & & & & & & & & - mmo & $1 \mathrm{c} / \mathrm{kc}$ & $9--$ & 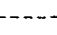 & ----- & - & : & & $\cdots$ & $--\frac{g}{8}$ & - & -- & -- & sil & Arg & AMF/ \\
\hline & & & & & & & & & $\mathrm{K}$ & $\mathrm{A} I$ & $\mathrm{H}+\mathrm{Al}$ & $\mathrm{SB}$ & СTC7 & $\mathrm{v}$ & m & $\mathrm{M}$ & G & $\mathrm{M}$ & $\mathrm{F}$ & MP & Tot & & Tot & $\mathrm{AF}$ \\
\hline 254 & $0-20$ & $7.54 / 2$ & 5,7 & 43,0 & 9 & 0,8 & 70 & 24 & 4,6 & 1 & 34 & 99 & 133 & 75 & 1 & 1 & 1 & 2 & 9 & 15 & 28 & 40 & 32 & 1,67 \\
\hline & $30-40$ & $54 / 6$ & 6,1 & 17,0 & 3 & 3.5 & 135 & 50 & 2,9 & 2 & 28 & 191 & 219 & 87 & 1 & 0 & 1 & 2 & 3 & 3 & 9 & 33 & 58 & 1,00 \\
\hline 257 & $0-20$ & $7.54 / 2$ & 5,6 & 15,0 & 12 & 0,3 & 13 & 5 & 2,1 & 0 & 16 & 20 & 36 & 56 & 0 & 1 & 2 & 21 & 43 & 11 & 78 & 14 & 8 & 0,26 \\
\hline & $60-80$ & $104 / 6$ & 5,6 & 8,0 & 2 & 0.2 & 7 & 2 & 0,6 & 0 & 12 & 10 & 22 & 45 & 0 & 1 & 2 & 21 & 44 & 14 & 82 & 10 & 8 & 0,32 \\
\hline 264 & $0-30$ & $7.5 \quad 3 / 2$ & 5,2 & 24,0 & 5 & 0,2 & 37 & 6 & 1,7 & 2 & 31 & 45 & 76 & 59 & 4 & 1 & 1 & 4 & 32 & 16 & 54 & 23 & 23 & 0,50 \\
\hline & $30-50$ & $54 / 4$ & 5,5 & 16,0 & 3 & 0,9 & 66 & 22 & 1,9 & 2 & 25 & 91 & 116 & 78 & 2 & 1 & 1 & 3 & 16 & 14 & 35 & 16 & 49 & 0,88 \\
\hline 265 & $0-20$ & $104 / 6$ & 5,2 & 15,0 & 3 & 0,3 & 30 & 9 & 1,4 & 11 & 34 & 41 & 75 & 54 & 21 & 1 & 1 & 3 & 27 & 9 & 41 & 22 & 37 & 0,33 \\
\hline • & $20-40$ & $54 / 4$ & 4,8 & 14,0 & 2 & 0,9 & 27 & 11 & 1,4 & 29 & 88 & 40 & 128 & 31 & 42 & 1 & 1 & 2 & 13 & 10 & 27 & 21 & 52 & 0,77 \\
\hline 266 & $0-20$ & $104 / 6$ & 4,9 & 12,0 & 4 & 0,2 & 12 & 5 & 2,2 & 6 & 25 & 19 & 44 & 44 & 24 & 0 & 1 & 4 & 42 & 20 & 67 & 17 & 16 & 0,48 \\
\hline & $60-80$ & $7.54 / 6$ & 5,5 & 11,0 & 2 & 0,3 & 24 & 28 & 1,7 & 3 & 28 & 54 & 82 & 66 & 5 & 0 & 0 & 2 & 34 & 12 & 48 & 12 & 40 & 0,35 \\
\hline 268 & $0-10$ & $103 / 4$ & 5,3 & 20,0 & 5 & 0,8 & 52 & 19 & 4,6 & ì & 34 & 76 & 110 & 69 & 0 & 1 & 1 & 2 & 23 & 8 & 35 & 30 & 35 & 0,35 \\
\hline & $10-30$ & $103 / 6$ & 5,1 & 16,0 & 8 & 1,7 & 63 & 20 & 4,3 & 13 & 42 & 89 & 131 & 68 & 13 & 1 & 1 & 2 & 11 & 9 & 24 & 33 & 43 & 0,82 \\
\hline 270 & $0-10$ & $103 / 3$ & 5,4 & 22,0 & 4 & 2,2 & 72 & 30 & 3,4 & 2 & 38 & 108 & 146 & 74 & 2 & 1 & 2 & 4 & 9 & 6 & 22 & 40 & 38 & 0,67 \\
\hline & $10-40$ & $104 / 4$ & 5,3 & 14,0 & 2 & 2,0 & 75 & 32 & 2,1 & 2 & 31 & 111 & 142 & 78 & 2 & 1 & 2 & 4 & 19 & 8 & 34 & 31 & 35 & 0,42 \\
\hline 271 & $0-10$ & $104 / 2$ & 5,4 & 20,0 & 2 & 0,4 & 41 & 16 & 1,8 & 2 & 22 & 59 & 81 & 73 & 3 & 1 & 1 & 3 & 34 & 13 & 52 & 20 & 28 & 0,38 \\
\hline & $10-30$ & $104 / 4$ & 5,6 & 14,0 & 2 & 0,6 & 49 & 16 & 1,0 & 2 & 25 & 67 & 92 & 73 & 3 & 1 & 1 & 2 & 33 & 9 & 46 & 18 & 36 & 0,27 \\
\hline 272 & $0-20$ & $7.5 \quad 4 / 4$ & 4,9 & 15,0 & 3 & 0,3 & 14 & 6 & 0,8 & 10 & 25 & 21 & 46 & 46 & 32 & 0 & 0 & 3 & 56 & 13 & 72 & 11 & 17 & 0,23 \\
\hline & $60-80$ & $7.5 \quad 4 / 4$ & 4,5 & 10,0 & 2 & 0,2 & 9 & 4 & 1,0 & 50 & 121 & 14 & 135 & 11 & 78 & . & : & - & . & * & . & $\star$ &. & " \\
\hline 275 & $0-20$ & $104 / 3$ & 4,9 & 13,0 & 10 & 0,4 & 28 & 12 & 2,8 & 4 & 22 & 43 & 65 & 66 & 8 & 0 & 1 & 6 & 48 & 16 & 71 & 14 & 15 & 0,33 \\
\hline & $60-80$ & $105 / 6$ & 4.8 & 10,0 & 3 & 0,2 & 28 & 8 & 0,9 & 24 & 47 & 37 & 84 & 44 & 39 & 0 & 0 & 5 & 43 & 17 & 65 & 10 & 25 & 0,40 \\
\hline 276 & $0-20$ & $105 / 4$ & 6,2 & 13,0 & 2 & 0,6 & 105 & 30 & 3,5 & 0 & 18 & 139 & 157 & 89 & 0 & 2 & 2 & 4 & 13 & 7 & 28 & 29 & 43 & 0,54 \\
\hline 277 & $0-20$ & $104 / 2$ & 4,8 & 12,0 & 12 & 0,2 & 7 & 2 & 2,0 & 6 & 18 & 11 & 29 & 38 & 35 & 0 & 0 & 5 & 80 & 13 & 98 & 1 & 1 & 0,16 \\
\hline & $80-100$ & $105 / 6$ & 5,5 & 11,0 & 1 & 0,2 & 32 & 7 & 1,8 & 4 & 20 & 41 & 61 & 67 & 9 & 0 & 0 & 2 & 50 & 12 & 64 & 6 & 30 & 0,24 \\
\hline 282 & $0-20$ & $104 / 2$ & 4,2 & 16,0 & 5 & 0,2 & 3 & 2 & 1,0 & 21 & 38 & 6 & 44 & 14 & 77 & 0 & 1 & 11 & 44 & 12 & 68 & 18 & 14 & 0,27 \\
\hline & $60-80$ & $104 / 3$ & 4,8 & 15,0 & 2 & 0,4 & 10 & 3 & 1,2 & 26 & 42 & 15 & 57 & 26 & 64 & 0 & 1 & 14 & 47 & 12 & 74 & 1 & 25 & 0,26 \\
\hline 284 & $0-20$ & $104 / 4$ & 4,2 & 16,0 & 10 & 0,2 & 3 & 1 & 1,2 & 6 & 22 & 5 & 27 & 20 & 53 & 0 & 0 & 5 & 68 & 10 & 83 & 8 & 9 & 0,15 \\
\hline & $60-80$ & $54 / 6$ & 5,7 & 11,0 & 1 & 0,2 & 45 & 10 & 0,9 & 2 & 22 & 56 & 78 & 72 & 3 & 0 & 0 & 2 & 41 & 15 & 58 & 8 & 34 & 0,37 \\
\hline 288 & $0-20$ & $106 / 3$ & 5,1 & 20,0 & 2 & 0,3 & 10 & 5 & 3,7 & 2 & 18 & 19 & 37 & 51 & 10 & 0 & 0 & 6 & 59 & 15 & 80 & 9 & 11 & 0,25 \\
\hline & $50-60$ & $104 / 4$ & 5,1 & 12,0 & 2 & 0,3 & 12 & 4 & 0,6 & 6 & 22 & 17 & 39 & 43 & 26 & 0 & 0 & 7 & 50 & 10 & 67 & 8 & 25 & 0,20 \\
\hline 290 & $0-20$ & $7.5 \quad 5 / 4$ & 5,5 & 19,0 & 2 & 0,3 & 44 & 25 & 5,1 & 2 & 25 & 74 & 99 & 75 & 3 & 1 & 2 & 4 & 18 & 10 & 35 & 29 & 36 & 0,56 \\
\hline 292 & $0-20$ & $103 / 3$ & 5,9 & 19,0 & 9 & 1,2 & 43 & 13 & 5,0 & 0 & 16 & 62 & 78 & 80 & 0 & 0 & 0 & 10 & 48 & 9 & 67 & 10 & 23 & 0,19 \\
\hline & $50-80$ & $103 / 2$ & 6,1 & 11,0 & 5 & 1.4 & 46 & 16 & 2,6 & 0 & 13 & 66 & 79 & 84 & 0 & 0 & 0 & 16 & 52 & 9 & 77 & 4 & 19 & 0,17 \\
\hline 293 & $0-20$ & $54 / 4$ & 5,4 & 30,0 & 4 & 0.6 & 64 & 26 & 3,3 & 0 & 34 & 94 & 128 & 73 & 0 & 1 & 1 & 5 & 14 & 4 & 25 & 33 & 42 & 0,29 \\
\hline & $20-30$ & $54 / 4$ & 5,3 & 20,0 & 4 & 0,6 & 68 & 35 & 3,5 & 2 & 31 & 107 & 138 & 78 & 2 & 2 & 3 & 4 & 11 & 4 & 24 & 33 & 43 & 0,36 \\
\hline 296 & $0-20$ & $7.54 / 4$ & 5,2 & 12,0 & 3 & 0,3 & 9 & 3 & 1,0 & 3 & 16 & 13 & 29 & 45 & 18 & 0 & 0 & 3 & 60 & 14 & 77 & 1.0 & 13 & 0,23 \\
\hline & $60-80$ & $54 / 4$ & 5,4 & 11,0 & 2 & 0,3 & 33 & 10 & 0,8 & 2 & 20 & 44 & 64 & 69 & 4 & 0 & 0 & 2 & 50 & 10 & 62 & 8 & 30 & 0,20 \\
\hline 302 & $0-40$ & $104 / 3$ & 4,6 & 15,0 & 6 & 0,3 & 9 & 2 & 0,8 & 12 & 34 & 12 & 46 & 26 & 50 & 0 & 1 & 14 & 40 & 9 & 64 & 16 & 20 & 0,23 \\
\hline & $40-80$ & $103 / 4$ & 4,8 & 12,0 & 3 & 0,8 & 20 & 4 & 0,8 & 25 & 47 & 26 & 73 & 35 & 49 & 0 & 1 & 16 & 31 & 11 & 59 & 14 & 27 & 0,35 \\
\hline 305 & $0-20$ & $7.54 / 2$ & 4,8 & 21,0 & 12 & 3,1 & 15 & 5 & 1,4 & 31 & 72 & 25 & 97 & 25 & 56 & 0 & 0 & 9 & 53 & 15 & 77 & 2 & $2 i$ & 0,28 \\
\hline & $40-60$ & $7.5 \quad 3 / 2$ & 5,9 & 12,0 & 2 & 21,2 & 16 & 14 & 1,1 & 28 & 47 & 52 & 99 & 53 & 35 & 0 & 0 & 12 & 46 & 12 & 70 & 9 & 21 & 0,26 \\
\hline 309 & $0-20$ & $104 / 3$ & 4,6 & 13,0 & 7 & 0,3 & 6 & 3 & 0,9 & 20 & 38 & 10 & 48 & 21 & 66 & 0 & 1 & 16 & 35 & 17 & 69 & 13 & 18 & 0,49 \\
\hline & $60-80$ & $103 / 3$ & 5,1 & 11,0 & 2 & 0,3 & 19 & 3 & 0,8 & 25 & 58 & 23 & 81 & 28 & 52 & 0 & 1 & 15 & 33 & 14 & 63 & 4 & 33 & 0,42 \\
\hline 311 & $0-20$ & $103 / 4$ & 5,4 & 13,0 & 2 & 1,3 & 41 & 13 & 1,3 & 2 & 22 & 57 & 79 & 72 & 3 & 0 & 1 & 3 & 27 & 24 & 55 & 23 & 22 & 0,89 \\
\hline & $80-100$ & $103 / 4$ & 5,5 & 18,0 & 3 & 1,4 & 54 & 16 & 0,9 & 0 & 22 & 72 & 94 & 77 & 0 & 0 & 1 & 3 & 25 & 18 & 47 & 27 & 26 & 0,72 \\
\hline 312 & $0-20$ & $103 / 2$ & 5,6 & 15,0 & 2 & 6,0 & 43 & 19 & 1,4 & 26 & 64 & 69 & 133 & 52 & 27 & 0 & 0 & 2 & 29 & 12 & 43 & 22 & 35 & 0,41 \\
\hline & $50-80$ & $7.54 / 2$ & 6,1 & 12,0 & 3 & 18,4 & 57 & 27 & 1,9 & 3 & 28 & 104 & 132 & 79 & 3 & 0 & 0 & 6 & 27 & 14 & 47 & 23 & 30 & 0,52 \\
\hline 313 & 0.10 & $103 / 3$ & 5,4 & 19,0 & 9 & 10,8 & 25 & 11 & 4,1 & 49 & 135 & 51 & 186 & 27 & 49 & 0 & 1 & 8 & 15 & 12 & 36 & 24 & 40 & 0,80 \\
\hline & $10-30$ & $54 / 2$ & 5,3 & 16,0 & 4 & 18,0 & 28 & 13 & 3,0 & 79 & 281 & 62 & 343 & 18 & 56 & 1 & 2 & 14 & 17 & 7 & 41 & 14 & 45 & 0,41 \\
\hline 315 & $0-20$ & $104 / 3$ & 4,5 & 11,0 & 3 & 0,3 & 1 & 1 & 0,6 & 10 & 22 & 3 & 25 & 12 & 78 & 0 & 1 & 11 & 60 & 14 & 86 & 10 & 4 & 0,23 \\
\hline & $70-90$ & $104 / 4$ & 4,9 & 13,0 & 2 & 0,2 & 23 & 4 & 1,1 & 13 & 38 & 28 & 66 & 43 & 31 & 0 & 0 & 9 & 43 & 11 & 63 & 12 & 25 & 0,26 \\
\hline 316 & $0-30$ & $54 / 3$ & 5,1 & 15,0 & 2 & 0,2 & 9 & 7 & 1,1 & 5 & 20 & 17 & 37 & 46 & 22 & 0 & 0 & 4 & 59 & 14 & 77 & 7 & 16 & 0,24 \\
\hline & $30-60$ & $54 / 4$ & 4.8 & 13,0 & 2 & 0,2 & 8 & 4 & 0,8 & 11 & 22 & 13 & 35 & 37 & 46 & 0 & 0 & 3 & 62 & 9 & 74 & 6 & 20 & 0,15 \\
\hline
\end{tabular}

Continua 


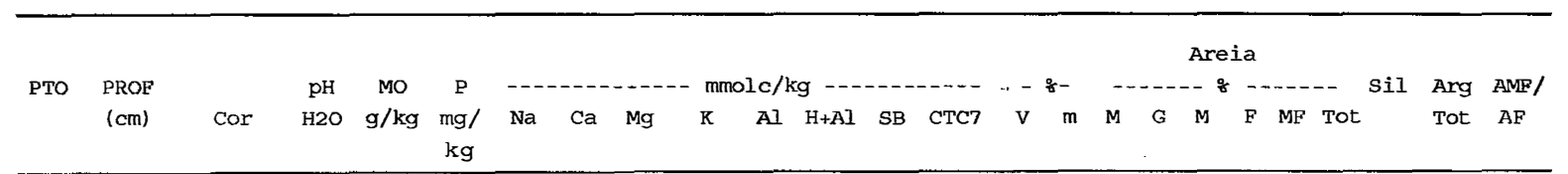

PBRFII 1 B TRADAGEM PROFUNDA DO TOPO

\begin{tabular}{|c|c|c|c|c|c|c|c|c|c|c|c|c|c|c|c|c|c|c|c|c|c|c|c|c|}
\hline Ap & $0-5$ & $5 \quad 5 / 2$ & 5,5 & 19,0 & 33 & 0,2 & 9 & 4 & 3,0 & 3 & 28 & 16 & 44 & 37 & 16 & 0 & 2 & 25 & 53 & 9 & 89 & 3 & B & 0,17 \\
\hline Ap1 & $5-25$ & $54 / 3$ & 5,4 & 19,0 & 46 & 0,2 & 13 & 5 & 1,0 & 3 & 34 & 19 & 53 & 36 & 14 & 0 & 3 & 28 & 48 & 6 & 85 & 5 & 10 & 0,13 \\
\hline Вw1 & $25-42$ & $54 / 6$ & 5,5 & 13,0 & 3 & 0,2 & 12 & 3 & 0,9 & 3 & 25 & 16 & 41 & 39 & 16 & 0 & 2 & 22 & 48 & 9 & 81 & 3 & 16 & 0,19 \\
\hline Bw2 & $42-57$ & $53 / 3$ & 5,0 & 19,0 & 3 & 0,2 & 4 & 2 & 0,8 & 8 & 58 & 7 & 65 & 11 & 53 & 0 & 3 & 23 & 52 & 8 & 86 & 4 & 10 & 0,15 \\
\hline BW3 & $57-150$ & $54 / 6$ & 5,2 & 12,0 & 2 & 0,2 & 7 & 1 & 1,2 & 9 & 34 & 9 & 43 & 22 & 49 & 0 & 2 & 20 & 50 & 10 & 82 & 4 & 14 & 0,20 \\
\hline BW & $150-200$ & $54 / 6$ & 5,5 & 9,0 & 2 & 0,2 & 17 & 1 & 0,4 & 2 & 22 & 19 & 41 & 46 & 10 & 0 & 2 & 22 & 47 & 9 & 80 & 5 & 15 & 0,19 \\
\hline Bพ & $200-250$ & $54 / 6$ & 5,4 & 9,0 & 1 & 0,2 & 13 & 1 & 0,2 & 3 & 20 & 14 & 34 & 42 & 17 & 0 & 2 & 20 & 49 & 10 & 81 & 3 & 16 & 0,20 \\
\hline $\mathrm{BW}$ & $250-300$ & $54 / 6$ & 4,6 & 9,0 & 1 & 0,2 & 5 & 1 & 0,2 & 8 & 22 & 6 & 28 & 23 & 56 & 0 & 1 & 19 & 35 & 7 & 62 & 8 & 30 & 0,20 \\
\hline $\mathrm{BW}$ & $300-350$ & $55 / 8$ & 4,6 & 9,0 & 1 & 0,2 & 4 & 1 & 0,2 & 8 & 22 & 5 & 27 & 20 & 60 & 0 & 2 & 28 & 41 & 7 & 78 & 4 & 18 & $0,1.7$ \\
\hline BW & $350-400$ & $2.54 / 8$ & 5,1 & 8,0 & 2 & 0,2 & 12 & 3 & 0,5 & 2 & 16 & 16 & 32 & 50 & 11 & 0 & 2 & 20 & 48 & 7 & 77 & 5 & 18 & 0,15 \\
\hline Bw & $400-450$ & $2.54 / 8$ & 5,1 & 8,0 & 1 & 0,2 & 9 & 4 & 0,3 & 2 & 16 & 14 & 30 & 46 & 13 & 0 & 2 & 20 & 44 & $B$ & 74 & 4 & 22 & 0,18 \\
\hline BW & $450-500$ & $2.54 / 8$ & 4,9 & 7,0 & 1 & 0,2 & 6 & 3 & 0,2 & 4 & 16 & 9 & 25 & 37 & 30 & 0 & 2 & 17 & 46 & 14 & 79 & 4 & 17 & 0,30 \\
\hline BW & $500-550$ & $2.54 / 8$ & 5,2 & 7,0 & 2 & 0,2 & 7 & 5 & 0,4 & 2 & 16 & 13 & 29 & 44 & 14 & 0 & 2 & 21 & 46 & 9 & 78 & 5 & 17 & 0,20 \\
\hline $\mathrm{BW}$ & $550-600$ & $2.54 / 8$ & 4,6 & 7,0 & 4 & 0,2 & 1 & 3 & 0,4 & B & 18 & 5 & 23 & 20 & 63 & 0 & 2 & 18 & 41 & 15 & 76 & 4 & 20 & 0,37 \\
\hline BW & $600-650$ & $2.54 / 8$ & 4,5 & 8.0 & 4 & 0,2 & 1 & 2 & 0,2 & B & 20 & 3 & 23 & 15 & 70 & 0 & 2 & 18 & 43 & 16 & 79 & 3 & 18 & 0,37 \\
\hline BW & $650-700$ & $2.54 / 8$ & 4,1 & 7,0 & 5 & 0,2 & 1 & 1 & 0,5 & 8 & 20 & 3 & 23 & 12 & 75 & 0 & 2 & 17 & 40 & 15 & 74 & 6 & 20 & 0,38 \\
\hline
\end{tabular}

PERFIL 2

$\begin{array}{lcrrrrrrrrrrrrrrrrrrrrrrrrrr}\text { Ap } & 0-5 & 10 & 4 / 1 & 5,4 & 47,0 & 13 & 0,3 & 39 & 11 & 2,1 & 0 & 20 & 52 & 72 & 72 & 0 & 0 & 1 & 16 & 46 & 25 & 88 & 8 & 4 & 0,54 \\ \text { B } & 5-22 & 10 & 6 / 3 & 5,1 & 12,0 & 2 & 0,2 & 4 & 2 & 0,9 & 3 & 15 & 7 & 22 & 32 & 30 & 0 & 1 & 14 & 42 & 37 & 94 & 4 & 2 & 0,88 \\ \text { B2 } & 22-68 & 7.5 & 5 / 4 & 4,9 & 9,0 & 1 & 0,2 & 1 & 1 & 0,3 & 8 & 20 & 3 & 23 & 11 & 76 & 0 & 1 & 14 & 44 & 31 & 90 & 6 & 4 & 0,70 \\ \text { Btg } & 68-110 & 5 & 5 / 6 & 4,2 & 9,0 & 1 & 0,2 & 3 & 1 & 0,4 & 23 & 80 & 5 & 85 & 5 & 83 & 0 & 1 & 11 & 32 & 30 & 74 & 4 & 22 & 0,94 \\ \text { BE } & 110-160 & 5 & 5 / 7 & 4,6 & 10,0 & 1 & 0,2 & 1 & 1 & 0,5 & 31 & 80 & 3 & 83 & 3 & 92 & 0 & 1 & 9 & 31 & 29 & 70 & 8 & 22 & 0,94 \\ \text { BL2 } & 160+ & 5 & 5 / 7 & 4,3 & 9,0 & 1 & 0,2 & 1 & 1 & 0,2 & 32 & 88 & 2 & 90 & 3 & 93 & 0 & 1 & 11 & 36 & 28 & 76 & 6 & 18 & 0,78\end{array}$

PEREIL 3

$\begin{array}{lcrrrrrrrrrrrrrrrrrrrrrrrrrrr}\text { Ap } & 0-45 & 105 / 3 & 5,6 & 12,0 & 2 & 0,2 & 11 & 2 & 2,6 & 3 & 20 & 16 & 36 & 44 & 16 & 0 & 0 & 4 & 74 & 4 & 82 & 7 & 11 & 0,05 \\ \text { B } & 45-54 & 7.5 & 6 / 4 & 5,8 & 9,0 & 2 & 0,2 & 11 & 2 & 0,9 & 1 & 13 & 14 & 27 & 52 & 7 & 0 & 0 & 4 & 73 & 5 & 82 & 10 & 8 & 0,07 \\ \text { Bt1 } & 54-100 & 7.5 / 46 & 5,7 & 12,0 & 1 & 0,3 & 49 & 9 & 0,9 & 1 & 22 & 59 & 81 & 73 & 2 & 0 & 0 & 4 & 61 & 2 & 67 & 8 & 25 & 0,03 \\ \text { Bt2 } & 100-190 & 54 / 6 & 5,5 & 9,0 & 1 & 0,2 & 35 & 18 & 0,5 & 4 & 28 & 54 & 82 & 66 & 7 & 0 & 0 & 3 & 52 & 3 & 58 & 11 & 31 & 0,06 \\ \text { Bt3 } & 190+ & 2.54 / 6 & 5,3 & 8,0 & 1 & 0,2 & 14 & 15 & 0,9 & 43 & 150 & 30 & 180 & 17 & 59 & 0 & 0 & 2 & 54 & 4 & 60 & 13 & 27 & 0,07\end{array}$

PERFIL 4

$\begin{array}{llllllllllllllllllllllllllllll}\text { A1 } & 0-5 & 5 & 3 / 3 & 5,5 & 41,0 & 27 & 0,5 & 85 & 25 & 6,4 & 0 & 38 & 117 & 155 & 75 & 0 & 5 & 5 & 4 & 9 & 2 & 25 & 35 & 40 & 0,22\end{array}$ $\begin{array}{lllllllllllllllllllllllllll}\text { A2 } & 5-12 & 2.5 & 3 / 4 & 5,4 & 26,0 & 4 & 0,5 & 79 & 17 & 4,8 & 2 & 47 & 101 & 148 & 68 & 2 & \# \# & 5 & 3 & 4 & 1 & 24 & 34 & 42 & 0,25\end{array}$ 